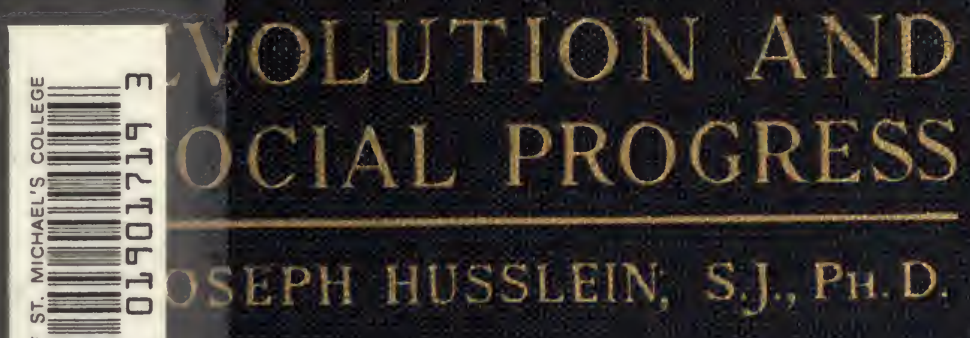



7.0 thede 

EVOLUTION AND
SOCIAL PROGRESS 

575

\section{EVOLUTION AND SOCIAL PROGRESS}

BY

\section{JOSEPH HUSSLEIN, S.J., Ph.D.'}

ASSOCIATE EDITOR OF "AMERICA"; LECTURER ON INDUSTRIAL" HISTORY, FORDHAM UNIVERSITY SCHOOL OF SOCIAL

SERVICE; AUTHOR OF "DEMOCRATIC INDUSTRY," "THE WORLD PROBLEM,"

ETC. EX LIBRIS

ST, BASIL'S SCHOLASTICATE

No. $2229-9 / 8 / 31$

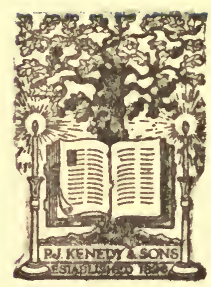

W. E. BLAKE \& SON, LIMITED CATHOLIC CHURCH SUPPLIES 123 CHURGH ST. TORONTO, CANADA 


\section{Jmprimi Potest:}

JOSEPHUS H. ROCKWELL, S.J.

Prapositus Proo. Marylandia Neo-Eboracensis

Sibn Obstat:

ARTHURUS J. SCANLAN, S.T.D.

Censor Librorum

Jmprimatur:

* PATRITIUS J. HAYES, D.D.

Archiepiscopus Neo-Eboracensis

Neo-EBoraci

die 14, Septembris, 1920
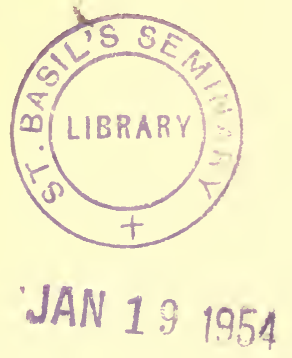

COPYRIGHT'I 920

BYP・J・KENEDY \& SONS

PRINTED IN $\mathrm{U}_{-} \cdot \mathbf{S} \cdot \mathbf{A} \cdot$ 


\section{TABLE OF CONTENTS}

Dedication-To the Classes and the Masses vii CHAPTER

I Sapping the Social Foundations • I

II Sowing the Storm . . . . . . 12

III Materialistic Evolution . . . . 22

IV Haeckel and the Monistic Creed . 38

V The Origin of Life

VI Darwin and Darwinism . . . 72

VII Twentieth Century Evolutionism . . 85

VIII Catholics and Evolution • • 95

IX Evolution and Genesis . . . 106

$\mathrm{X}$ How the Earth Was Made . 117

XI How Life Appeared on Earth • . 124

XII Man's Reported Ancestry . . . I42

XIII The Missing Link . . . . . . I53

XIV Does Likeness Prove Descent? . 165

XV Leading Arguments for Descent • $\mathbf{1 7 6}$

XVI The Church and Man's Origin . . I87

XVII Antiquity of the Human Race • . 202

XVIII Our First Parents . . . . . . 217

XIX Primitive Man and Woman . . . 227

XX What Pick and Shovel Reveal . . 237

XXI The Decline of Men and Races . 247 -

XXII The Course of History . . . . 255

XXIII "The Fool Hath Said" . . . . 264

XXIV What the Mountains Saw . . 274 



\section{TO THE CLASSES AND THE MASSES}

$7 \mathrm{HE}$ subject treated here calls for no introduction. Its significance for the man in the street is no less than for the scientist and philosopher, the clergyman and student, the sociologist and journalist. It is of all questions the most fundamental as it is the most far-reaching in its consequences. It is at the basis not merely of our science and our popular literature, but also of our commercial transactions and our labor troubles, of our public morality and the welfare or ruin of nations. All this is made abundantly clear to the reader in the present vol. ume.

Men believe in God or in materialistic evolution. There is no other alternative. Scientists plainly state this fact, and the masses have not failed to grasp it.

Worker and capitalist, professional man and university professor, the great public and the social élite equally absorbed the evolutionary ideas of the nineteenth century. The technicalities of science did not frighten them away. What then they studied is now taken for granted. To-day they are drawing their logical conclusions. 


\section{viii}

We have stood at the deathbed of Darwinism, but not of evolution, whether in its materialistic or Christian sense. Evolutionary theories are of many kinds. Evolution itself was expounded long ago by no less a teacher than St. Augustine himself. Literally, everything depends upon the right or wrong interpretation that men give to it.

Here then is a question that urgently requires to be treated, simply, scientifically, honestly, in all its totality, with no evasion, with nothing left obscured or hidden-for the classes and the masses. It must be set forth in all its profound human interest, and applied in its vital relations to the Sacred Scriptures, to religion, to history, and to our own conduct. To do this has been the aim of the author, whose book has grown out of his lecture work in the university classroom. For its scientific accuracy special acknowledgment is due to A. F. Frumveller, S.J., Ph.D., Professor of Mathematics at Marquette University.

The realization of the supreme practical consequences of this subject has constantly grown in the writer's mind with his own widening experience. A clear understanding of it is equally imperative for the student and the worker. Countless minds perplexed by it must be set at rest. For the school, the pulpit, the press, the platform, and the wide university of the streets, this book is intended. To the classes and the masses it is dedicated. 


\title{
EVOLUTION AND SOCIAL PROGRESS
}

\author{
C H A P T E R I
}

\section{SAPPING THE SOCIAL FOUNDATIONS}

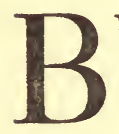

UT now really, tell me, between ourselves, Ivan: Does God exist-yes or no?"

Such is the question asked in a modern play, a harrowing dramatization of a gruesome Russian novel. The questioner himself is a sinister old man, a repulsive sensualist, whose fortune has been wasted in unrestrained self-indulgence. Ivan, his son, from whom he seeks an answer which he hopes will allay his fears, is an advanced radical, whose intellectual training has left him an atheist and a cynic. He is the consistent product of a rationalistic education.

"No, God does not exist," comes the cold reply, as Ivan leans upon his elbow and stares at his father in disgust.

"Is that right?" the old man eagerly queries. "And immortality? Is there such a thing?"

Again the curt, monosyllabic reply: "No." 
There is a visible feeling of relief on the part of the hoary transgressor of the laws of God as he earnestly urges his questions and finally presses the answers to their logical conclusion.

"Are you sure, my little Ivan? You are not making fun of me? No immortality-not the least scrap of immortality?"

"Nothing!"

"That is to say - an absolute zero? Not even the fraction of a fraction?"

"Absolute zero!"

"But then-then-everything is permitted! Ivan, everything is allowable?"

"Yes, father, everything is permitted."

"Hush-let's not say that aloud. Leit us keep that as our secret, my son."

There is the terrible logic that has produced the lust and cruelty, the bloodshed and injustice of the modern as of the ancient paganism. The practical conclusions of that same reasoning on the part of the rich have been the oppressive industrialism and the godless excesses of ill-gotten wealth; while on the part of the poor they have led to the deeds of anarchism and the orgies of bloody revolutions. From this same argument were begotten the Nietzschean madness and the Bolshevist dream with its awakening in hunger, loot and murder: a new tyranny for the old.

If there is no God then everything is permissible, everything is allowable. Nothing more 
is required than the mere power to carry out our desires. There is no conscience any longer to stay the passions of men, their greed or immorality; for there is no one to whom henceforth they are held accountable? Hence the counsel of the hoary sensualist in the Russian novel who wished indeed to draw this conclusion for himself alone that it might not be applied against him in turn: "Let's not say that aloud. Let us keep that as our secret."

But it is not included in the devil's program that this logical conclusion from the atheist's premises, wrongly said to be based upon natural science, should ever be kept secret. It is too serviceable for his purpose.

Why should laborers not be anarchists, I. W. W., Nihilists or Bolsheviki, if there were no God, and these plans and methods promised them the control of wealth which they are determined to acquire? Why should capitalists not be extortioners and profiteers?

Admit the false premise that there is no God, and we may well defy all the universities in the world to point out any flaw in the argument: "Then everything is permitted, Ivan, everything is allowable." Everything is allowable! There would then be no punishment hereafter for $\sin$ and no reward for virtue.

Here we have sounded the depth of capitalist injustice and of labor revolution; we have touched 
on the bedrock of the modern social problem as well as of countless other questions for which there will be no solution until religion is restored to the hearts of men.

If there is no God, no immortality, then everything is permitted, everything is allowable. That is the pith and kernel of the entire atheist philosophy when reduced to practice. Only see to it that no one shall detect you, or no one can bring you to harm. Such was the law of paganism, and such will again be the law wherever religion is ignored.

The traditions of our day are still, we must remember, the traditions of Christianity. Their influence cannot at once be eradicated. It is felt even by those who ignore them entirely. But given a godless education for generations to come, and these traditions also would disappear from the minds of the masses within the nation which had thus blindly offended against reason and sinned against God. Unaided by religion, the natural law will in practice be too weak to withstand the violent assaults of passion and the promptings of an unholy selfishness. Logically indeed, we cannot even admit the existence of a natural moral law, that man could be bound to obey, if there were no God. The obligation of obedience cannot come from a blind nature, but only from a living Creator. We must return, in 
brief, to the conclusion that everything would be permitted, everything allowable.

Without soul, without God, man were but a brute among his fellow brutes. Who then could demand from him obedience to any law save that of fear only? Who then could ask of him the observance of any code of morality, save selfinterest. The gratification of his instincts, when not prevented by outward force or peril, would be his only law. We would in fact be obliged to proceed much further, and deny him all freedom of will, as the materialists have most consistently done. With the cessation of free will all accountability is gone. Punishments and rewards are then both absurdities, as certain materialistic sociologists entirely admit, and as all should admit if they were logical. There can be no patriotism, no loyalty, no virtue, no crime. The moral order would have come to its end.

Such, then, would be the fate of a world blinding its eyes to the evidence of the truth, and with the fool exclaiming in its heart: "There is no God." The law of the jungle could be the only law of the land and the law of the nations in their dealing with each other. We have gone a great way in this direction. We must go the full length if we would accept as true the basis of most modern sociology, which is nothing else than materialistic evolution.

There are two kinds of evolutionary theories, 
let it be said at once and made perfectly clear. They may be described respectively as scientific and materialistic evolution.

The former deals with well established facts and probable theories. Its conclusions are not wider than its premises. It is scrupulously careful to distinguish between undeniable evidence, gathered from nature, and mere theories, resting upon what is at the best a likelihood. It finally remains strictly within its own sphere, and is therefore truly scientific. The latter disregards completely the limits of its scientific province, and leaps into the foreign realm of metaphysics and religion with which, as physical science, it is wholly incompetent to deal. In place of facts it substitutes unproved fancies and unprovable theories, converting them into dogmas and creeds. Its openly avowed purpose is to destroy from the hearts of men every vestige of a Personal Creator.

Many doubtless there are who accept it as the sole alternative of admitting the existence of a Divine Power. Thus M. Yves Delage, a scientist of no slight significance and professor of the Sorbonne, thus clearly states his own attitude:

I can easily admit that one species has never been seen to give rise to, or to be transformed into another, and that it cannot be formally proved ever to have done so. I am now speaking of a real and true species, fixed as natural species, and like them maintaining itself without human assistance. Much more, of course, is all this true of genus.

Yet I consider descent [understood here as materialistic evolu- 
tion] as certain a fact as if it were objectively proved, for without it there is no other possible hypothesis than that of spontaneous generation of all species, even of the higher orders, and that of their creation by some Divine power. ${ }^{1}$

Spontaneous generation cannot be scientifically accepted, as we fully agree with him. There consequently remains but the alternative of materialistic evolution or Creation. Because he will not accept the latter, he is driven to admit the former, not merely without proof, as he confessed, but against the testimony of reason itself. This is a point we shall later conclusively show. But what are we to think of a school of scientists who allow themselves to be blindly swayed by convictions which are in no way based upon physical science, but upon atheistic philosophy alone? For in his confession M. Yves Delage implicates the whole school of materialistic evolutionists-those, that is, who assert evolution without God to be a certainty, while at the same time they are obliged to admit that their assertion lies entirely beyond the realm of proof, that in other words, it is merely a subterfuge to escape the inevitable fact of a Creator God. Says M. Yves Delage:

I am however absolutely convinced that a man supports or does not support transformism [again understood as materialistic evolution], not for reasons taken from natural history, but because of his philosophical views. If there were any other

${ }^{2}$ La Structure du Protoplasma et les Théories sur l'Hérédité, p. 184. See Cardinal Mercier, "The Origins of Contemporary Psychology," pp. 316-319. Professor Kellogg, it may be noted, follows the same line of argument. 
scientific hypothesis than that of descent to explain the origin of species, a number of transformists would give up their present opinions as insufficiently proved. ${ }^{2}$

Compare with this the scientific attitude of the Catholic scientist who, without fear or hesitation, is willing to admit evolution precisely so far as it can be established by fact. His Faith does not impede his researches but preserves him from rash deductions, and may often point the right way where science has no final answer to give. He approaches his investigation unhampered by any prejudice, with no eagerness for anything except to ascertain the truth, the full truth, and nothing but the truth. The fear that this truth can ever, even in the slightest detail, conflict with his faith will never enter the mind of the real Catholic scientist, who has been trained to welcome every fact of science without reserve or suspicion-provided that it is a fact and not a mere hypothesis which may be changed tomorrow. His unshaken belief in a Creator merely rounds out and completes his knowledge, giving logical consistency to all his thought. It does not obstruct, but perfects his vision. Nothing is more wide of the truth than the assumption that physics and metaphysics, when both pursued in a truly scientific way, can ever be in the slightest conflict with one another. Here, in brief, is the logical argument of Christian metaphysics, as pithily and authoritatively

${ }^{2}$ Ibid. 
stated by one who was honored for his learning no less than for his patriotism by many of our greatest secular universities, Cardinal Mercier:

Man and external beings are contingent-i.e., in none of them does essence imply existence-and nevertheless they exist. Hence there is something which has brought them into existence. If this cause were itself contingent, it would not altogether resolve the problem of their existence, because it must have a cause for itself. Therefore contingent existence must have a cause that is itself non-contingent, necessary-by which we mean that its essence is identical with its existence.

Therefore it is on the ground of experience that the existence of a necessary Being is affirmed. Reason compels us to choose between affirming the existence of God or else maintaining an essential contradiction at the very heart of that contingent being, the existence of which we have ascertained. ${ }^{3}$

Either this, or chaos, both in the intellectual and the moral world! There is no deduction of science that can be claimed to be more reasonable, none that can be more imperative than the first conclusion here arrived at, affirming "the existence of a necessary Being." At the same time it in no way encroaches upon the domain of any of the natural sciences, but accepting all the facts they have discovered, or may yet discover, it finds in them only a firmer warrant for its logical necessity and indisputable truth.

Even Kant could not fail to acknowledge the logical necessity of these conclusions when he wrote:

3 "The Origins of Contemporary Psychology," pp. 314, 315. 
It is impossible to contemplate the fabric of the world without recognizing the certain manifestations of the hand of God in the perfection of its correlations. Reason, when once it has considered and admired so much beauty and so much perfection, feels a just indignation at the dauntless folly which dares to ascribe all this to chance and a happy accident. It must be that the highest wisdom conceived the plan, and infinite power carried it into execution. All things which set forth reciprocal harmonies in nature must be bound together in a single Existence on which they collectively depend. Thus there exists a Being of all beings, an infinite Understanding and a self-existent Wisdom, from which nature, in the whole aggregate of her correlations, derives existence. It is not allowable to maintain that the activity of nature is prejudicial to the existence of a highest Being. The perfection of its development, the order and harmony of its laws, give conclusive demonstration of the Godhead from whom these relations are derived."

The various statements made in this chapter call for further explanation and proof, such as shall be abundantly given in the following chapters. There is no antagonism between true science and true religion. And here it may at once be plainly declared by the writer that in the many years spent by him in the study of social questions, or in lectures upon social topics, whether in university classrooms or in the public forum, experience has daily borne in more strongly upon his mind the conviction that the immediate cause of our present evils must be sought mainly in the vast and world-wide propaganda carried on in the interest of an untenable materialistic evolution. Mr. Loeb well expressed the animus of this move.

\footnotetext{
"Translation quoted in Detroit Journal, Oct. 15, 1917.
} 
nent when he said in the Nation: "The theories of evolution cannot be considered as an addition to our knowledge, since they are not based upon experiments, although they have acted as a valuable stimulus in the revolt against Church authority." 5 Its promoters, with most admirable energy but most unscientific deductions, allowed themselves neither rest nor respite until their dogmas, wholly unprovable, dominated the press, the school, and almost every channel of public information. Here is the direct historic reason, after the rejection of the Church, for the godlessness of the people and their rulers, in which our social evils are ultimately rooted.

Sept. 7, 1918. 


\section{SOWING THE STORM}

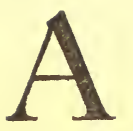

CAREFUL perusal of modern social literature cannot fail to impress the intelligent Christian reader with the fact that the root of all our social errors is to be found in the dogma of materialistic evolution. The philosophy of Socialism is merely an application of it. Society is explained as a series of inevitable evolutions that began with the lowest forms of animal life and continued to the present day, according to strictly economic laws. Every form of modern institution, the Church included, is said to have been determined mainly by economic conditions. Historic materialism is the name quite properly given by its authors to this Socialist creed. The same dogma of materialistic evolution, accepted in a wider sense, is the first principle of practically all the purely secular social literature of our day. It is equally popular with Communist, anarchist and rationalistic capitalist.

So completely has this new doctrine of evolution without God obsessed the mind of the present generation that it is almost impossible to take up a handbook of economics, sociology, history, 
science or philosophy, used in our public schools and in our universities, in which this lowest form of materialism is not an accepted dogma. "There is more ineffable rot being taught in the universities of the United States," rightly said Senator Sherman in a debate on the literacy test, "than can be found in the whole of the ignorant slums of the entire world." The same is true of the universities of other lands. Never perhaps were so many vital truths ignored, never was sound learning less in honor, never was investigation carried on in a more partisan and less unbiased spirit, never was superstition enthroned in the place of religion with such fatal consequences as in the years preceding the World War.

We still remember the well-justified charges brought against American colleges by Harold Bolce, in 1910. His conclusions were drawn only after he had attended lectures in more than a hundred of the secular institutions of higher learning, and the lectures heard by him were for the most part merely the echoes of what was then being taught throughout the universities of Europe. Here is the editorial summary that prefaced his article:

Those who are not in close touch with the colleges of the country will be astonished to learn the creeds being fostered by the faculties of our great universities. In hundreds of classrooms it is being taught daily that the decalogue is no more sacred than a syllabus; that the home as an institution is doomed; that there are no absolute evils; that immorality is 


\section{4}

simply an act in controvention of society's standards; that democracy is a failure and the Declaration of Independence only spectacular rhetoric; that the change from one religion to another is like getting a new hat; that moral precepts are passing shibboleths; that conceptions of right and wrong are as unstable as styles of dress; that wide stair-ways are open between social levels, but that to the climber children are an encumbrance; that the sole effect of prolificacy is to fill tiny graves, and that there can be and are holier alliances without the marriage bond than within it. ${ }^{1}$

That there was no exaggeration in these statements every one acquainted with the teachings of these universities knows perfectlly well. All these conclusions regarding the most sacred institutions, and the most fundamental moral principles, naturally flow from the prime doctrine of materialistic evolution. They would all be true if this original premise were not itself false as the father of lies. This we shall easily and fully make clear in the present volume, arguing from the standpoint of science itself and from the standpoint of scientific evolution, which we have not the slightest desire to oppose or antagonize. We are concerned with facts alone and shall enable the reader to form his unprejudiced decision.

But with doctrines such as the above submitted with academic warrant to the minds of hundreds of thousands of students, not in the United States only, but in England no less and on the continent of Europe; with the professed guardians of the

1 "Blasting at the Rock of Ages." Bolce's articles originally appeared in the Cosmopolitan. 
founts of learning babbling over and over again the same old, unproven Haeckelian lessons, until they were learned by rote, can we wonder that the nations should have been ripe for the cataclysm of the World War, for the Spartacan and Bolshevist outbreaks, for the excesses of a Bela Kun and a Trotzky following in the wake of Marx and Ferrer. Yet these were merely premonitions of the things to come if a sounder and more scientific basis is not laid for our learning. They who sow the storm must reap the whirlwind.

Our entire view of life will obviously take shape and color according as we admit or reject a Divine plan. Nothing could be more childish than to imagine that evolution can disprove the existence of God. In the order of pure reason it could merely postpone the difficulty which the evolutionist so painfully and futilely seeks to avoid: "And who then gave the laws of evolution?" Only a mind distorted and distraught could fancy the ordered beauty of nature and the marvel of human life, with its mystery of reproduction, as existent without an intelligent primal and directive cause. This can evidently not be contingent, like the material universe about us, but must be a simple, immaterial, necessary being.

Whether civilization is ever to attain closer to its ideal perfection, or in spite of all its material culture or kultur is to sink ever deeper into the mire of lewd passions and brutal instincts, as did 
ancient Greece and Rome before their fall, depends entirely upon its belief in the truths of Revelation, as preceded by the invincible evidences of reason, or its acceptance instead of the irrational dogma taught in thousands of the schools and universities of our day. If man is a brute in origin, with but one and the same destiny as the brute, why should he not live like the brute?

The first logical consequence of the acceptance of the dogma of materialistic evolution is the denial of the free will. If nothing exists except matter and force, there can obviously be no moral liberty. Physical laws or chemical actions and reactions can clearly possess no freedom. So human agents could be no more virtuous or criminal than the wind and the waste sea when they drown the wrecked sailor or toss him about on the floating $\log$ and wash him to the shore. We should then heartily agree with Enrico Ferri, when he proclaims "the palpable refutations by physio-psychology of the presupposition of free choice or moral liberty,' and declares "the theoretical and practical impossibility of resting man's responsibility for his crimes upon free choice, either absolute or relative." "

It is true that evolution is not the only argument advanced for these theories, but it is the basic argument. It is moreover the only logical and conclusive argument that would necessitate

s"Criminal Sociology," p. 308. 
the denial of free will, once its false evolutionary premises were accepted. Thus when Ferri strives to prove statistically that "there is no free will" by the argument that "those human acts which are believed to be more free morally, such as marriages, suicides, crimes or emigrations, were on the contrary subject to the influences of environment and varied with these influences," for the sake of argument we can readily grant the entire statement. It does not disprove the existence of free will. It merely illustrates the fact that men, being similarly constituted, will under the same conditions ordinarily make the same choice when this recommends itself to their intelligence by intrinsic reasons, or else exercises a strong natural appeal on their senses. The impossibility of acting otherwise does not follow. It is easy in practice to prove the contrary in our own case. It is the dogma of materialistic evolution only, as taught in the godless schools of our day, that postulates the denial of a free will.

Admitting materialistic evolution there is no escape from the further conclusion that human responsibility is merely an idle phrase. "Not Guilty" is the title given by Robert Blatchford to one of his ultra-radical productions. The name itself is meant to indicate at once the verdict passed by him upon the criminal behind the prison bars. Men are what heredity and environment make them, is the substance of this doctrine of 
penology; free will is non-existent, blame and punishment are unjust and unreasonable. Nothing then remains to be done except to change the environment and so overcome the taint of heredity. He plainly says :

If our heredity and environment be good, we must act well, we cannot help it; if it be ill, we must act ill, we cannot help it. Suppose a tramp has murdered a child on the highway, has robbed her of a few coppers and has thrown her body into a ditch: Do you mean to say that tramp could not help doing that? Do you mean he is not to blame-not to be punished? Yes, I mean to say all these things, and if all these things are not true, this book is not worth the paper it is written on.

Admirably logical! And if all this is not true then neither is materialistic evolution worth being taught in our universities. Free will, as Haeckel himself clearly admits, and as every materialistic evolutionist must admit, is made impossible by it, since human thoughts, our supposed resolutions and outward actions can then be no more than the result of physical laws and chemical actions, which are not free but necessary in the strictest sense. No fine-spun explanations can change this conclusion. For, says Haeckel, "The various phenomena of nature [whether those we are accustomed to call mental or those we know to be material] differ in the degree of complexity only in which the different forces work together." " No degree of complexity in a chemical reaction can

s "Not Guilty."

" "The Evolution of Man." 
leave free will as its residue at the bottom of a test tube, no matter to what degree of Fahrenheit you may have raised its contents. No more can it produce this same result in the human compound. Haeckel is right in denying free will if there is nothing in the universe but matter and force; and equally right is Blatchford on that same supposition when he draws from it the inescapable conclusion that no criminal, no matter how vile and abhorrent his deeds, should ever be judged because of them. Considered purely as results of physical laws and chemical reactions, are they not just as admirable as the highest acts of virtue? Yet if the accepted teaching of an irreligious education is correct, if matter and force are all, if materialistic evolution is the ultimate word, then surely they are nothing more than that.

Although no criminal, therefore, must then be considered guilty, yet for the good of society, it is thought by Blatchford, that he may be temporarily kept in confinement made as delightful as possible. Such is the brief abstract of this pleasant doctrine that so highly recommends itself to modern criminologists and is most eminently reasonable on the ground of materialistic evolution.

Not merely is "idiocy a reversion, crime a disease, free will a delusion and religion an emotion," according to the doctrine of our advanced sociologists, but their code of morality and social 
life is not seldom deduced from the lower animals themselves. If God does not exist and man is but an evolutionary development of the ape, or a near cousin to him, derived from a common primitive stock, it is but natural that he should turn to the simple life of his ancestral race and so regain the unhampered freedom and the unconventional liberty of which Christianity has robbed him by its matrimonial laws and other "immoral" restrictions. Often the great bulk of modern social works is consistently devoted to investigations into the "morality" and social practices of the apes in an African jungle, or other bestial so called ancestry of man in order to remodel our moral code.

The promoters of materialistic evolution can evidently not admit any unchanging laws of morality. According to the leading Socialist authorities upon this subject, everything is moral in the present state of society that advances the cause of the social revolution. When this has been accomplished a new morality will arise. Other modern writers are equally consistent in denying the existence of any unalterable principles of morality. "Morality is a purely human matter," says the Harvard professor, B. M. Anderson, expressing the general consensus of his class. "It grows out of the needs and interests of men. What is good at one time and place is not necessarily good at another time and place. There 
are no immutable moral principles valid through the ages." He must consequently admit that there are "many sets of moral values," and defines the moral law as simply: "The will of the group." This he holds to be "the reigning type of moral theory today." ${ }_{5}$ If the will of a group is Bolshevist, then Bolshevism is its true morality. If free love and murder are the will of a group, then this is the true morality.

While the dogma of materialistic evolution naturally leads men to these conclusions, strict consistency must go still further, as we have shown, and demand the rejection of all claims to morality of whatever kind. The new creed, cunningly invented to displace Christianity, admits of nothing but matter and force. It can acknowledge in man no activities that are not the necessary result of purely physical and chemical forces, as little connected with any concept of morality as are the laws of gravitation. Hence the end of all liberty of action, of all responsibility and of all morality in human conduct. Elaborate explanations, couched in bewildering phraseology, are but dust in our eyes. The people cannot be so easily deluded. Admitting the false dogma of materialistic evolution, there is but one verdict to be passed upon the sensualist and criminal, upon Spartacide and anarchist, and that is: "Not Guilty."

"The Value of Money," pp. 22, $f$. 


\section{H A P T E R I I I}

\section{MATERIALISTIC EVOLUTION}

7 HE popular materialistic creed, most widespread during the latter part of the

1 nineteenth century, can be thus briefly summarized: In the beginning was matter. To this was added in some occult and forever inexplicable manner, force, which eventuated in motion. Hence materialistic evolution. Hence the world without God. The Creator was no longer needed. The lights of heaven were extinguished.

Haeckelian Monism was but an extension of this creed.

All, therefore, that had ever existed, would or could exist, was to be considered merely as a changing form of matter. From nebula to man, from the lowest clod to the highest genius, from the basest and most criminal passion to the tenderest emotion of a mother's love, from the turning of a worm to the rapture of a saint, all was purely a physical and chemical process.

"The human mind itself," wrote Tyndall, "emotion, will, intellect, and all their phenomena, were once latent in a fiery cloud." Plato, Shakespeare, Newton, Raphael, he declared to an ad- 
miring age, are even now potential in the fires of the sun. Out of lifeless matter they had developed in common with the toad and reptile, by no other power than material evolution. Without any intervention of purpose or intelligence, man had evolved, out of the blazing cloud of warring atoms and through the welter of a miry world, first as a primal cell, then as a structureless jelly, and so through eon after eon of evolution, until he attained his present stature of body and wonderful development of mind.

"Life is but an arrangement of matter, so as to live," wrote Edward Clodd, a popular purveyor of atheistic lore, "mind is but an arrangement, so as to think. The chemic lump arrives at the plant and grows; arrives at the quadruped and walks; arrives at man and thinks." This, in gross language, was the new creed, impossible of proof as its defenders were obliged to admit, yet for which an absolute submission of reason was demanded. To differ from it was heresy. To question it was ignorance. To accept any other dogma, though based upon the most convincing evidences of credibility, was superstition. To dare appear in print without subscribing to each of its leading articles was certain to result in scientific ostracism. The reign of materialistic evolution, extending over scientific circles, schools and popular literature, was in brief the worst and most disastrous autocracy of the nineteenth cen- 
tury. It still continued in power at the opening of the twentieth century, but a strong reaction had already begun to set in on the part of scientific men, while the popular pendulum was swinging to the opposite extreme of an equally unscientific spiritism.

Characteristic of the period of materialistic evolution was the almost superstitious veneration paid to learned names. An adversary might be cowed into silence, an audience could be spellbound with admiration or led to any length of absurdity, by the mere enumeration, in the speaker's favor, of these petty divinities of learning. Equally characteristic was their own delight in speaking with assumed infallibility upon any subject no matter how completely out of their ken. The biologist strutted about in the mantle of the metaphysician, and the clever inventor pronounced sententiously upon the immortality of the soul.

\section{I am Sir Oracle,}

And, when I ope my lips, let no dog bark!

Such was the warning solemnly given a credulous public. The obvious humor of the situation never for once dawned upon the actors themselves or their rapt admirers. It was all a delicious melodrama, save for its tragic aspects, a historicotragico-comedy, as Polonius might say.

Long before the World War had broken out the number of scientists who looked upon the common evolutionary origin of all plant and animal 
life as a mere figment of the imagination was constantly increasing. The fabulous lines of descent by which man was traced back to the primitive cell, and the Haeckelian succession of primates, were recognized by evolutionists themselves to be far more mythical than the lists of Homeric heroes. There was at least an historic foundation for ine great Greek epics.

The fallacy of materialistic evolution was made possible by the confusion of philosophy with science. Materialism and evolution were belived to be inseparable. Yet nothing can be more plain than the fact that materialism is purely philosophical, while evolution is as purely a theory, rightly or wrongly based on evidence, and limited by this. It is not against any sane theory of transformism that these chapters are directed, but against the materialism that many sought to confound with evolution.

Defending the probability of evolution in regard to certain investigations made by him, the Jesuit evolutionist Wasmann says: "The principle of the theory of evolution is the only one which supplies me with a natural explanation of these phenomena, and therefore I accept it." But how far was he to accept it? Down to the evolution of man from the primal cell? In answering this question he thus briefly formulated the rule by which every true scientist must be guided if he would remain within the limits of reason: "Just 
so far as its application is supported by actual proof." " These are the only restrictions that the Church would place upon science; the bounds of truth and fact.

Evolution, as every true scientist knows, does not offer certainty, but a measure of probability only, greater or smaller as the case may be, within rather indefinite limits. Science expresses this truth in a single word when it speaks of the "theory" or "theories" of evolution. The more closely plants or animals can be scientifically classed together, the greater the evolutionary probability. The more remote they are from each other, the less is that probability, until it finally vanishes altogether. More than this cannot be claimed with scientific accuracy by any evolutionist. Father Wasmann thus clearly states the entire matter from his own transformist viewpoint, the viewpoint of an unquestioned authority in evolutionary lore:

In the case of the species of the same genus, the genera of the same family, and often for the families of the same ordereven for orders of the same class-the probability is in support of evolution, and we meet with actual points of contact proving the relationship between the various forms. But the higher we ascend in the systematic categories, and the more closely we approach the great chief types of the animal world, the scantier becomes the evidence. In fact it fails so completely that we are finally forced to acknowledge, that the assumption of a monophyletic evolution (i.e., from one single parent form) of the whole kingdom of organic life is a delightful dream without

${ }^{1}$ Erich Wasmann, S. J., "The Problem of Evolution," p. I3. 
any scientific support. The same may be said of the assumed monophyletic evolution of the whole animal kingdom on the one hand, and of the whole vegetable kingdom on the other, from one primary form respectively.

The suggestion is quite prudently made by him that some 2000 years from now we may possibly know something more definite. But this at present is the extent of our knowledge, based upon entirely fragmentary evidence which in the minds of not a few deep and careful thinkers fails to support even the probability of any true evolution of species. In saying this it is important to remember, however, that the word "species" itself has been given almost as many meanings as there are men using it. No man of even moderate information will question the facts of transformism as verified in the mutations of mere varieties.

To be told now that Darwin himself expressly stated that there was no cogency of evidence to compel the intellect to admit the evolutionary change of even one single species into another, may still convey a gentle shock to some minds. The word "species" must not, of course, be understood here as a "variety," but should be taken in a strict sense. In a letter written to Bentham, Darwin definitely states: "When we descend to details, we can prove that no one species has changed." These words his son Francis softens down to mean that: "We cannot prove that a single species has

${ }^{2}$ Ibid., p. I5. 
changed." ' Referring, therefore, to those who wholly deny every form of real evolution and cling to the immutability of species-a position which Darwin thus claims cannot be shaken by any final demonstration-he adds these significant words: "I for one can conscientiously declare that I never feel surprised at any one sticking to the belief in immutability. . . . I remember too well my endless oscillations of doubt and difficulty." “

"After long and careful investigation," wrote the zoologist Professor Fleischmann of Erlangen, in his well-known book, "Die Descendenztheorie," "I have come to the conclusion that the doctrine of descent has not been substantiated."

These passages are rather different from the brazenness, either of ignorance or wilful deception, that would claim with dictatorial assurance the certainty of the whole range of evolution, from moneron to man. Even that ardent apostle of materialistic evolution, Professor Vernon L. Kellogg, who makes of the purely mechanical conception even of life itself, a scientific creed, and rejects as inadmissible all conclusions that conflict with its infallible contentions, plainly states that there is no evidence in nature for the evolutionary theory of descent, but that the only "evidence" we can possess exists solely in the mind of the scientist. This is the meaning of his words when he s "The Life and Letters of Charles Darwin," edited by his son, Francis Darwin, I, p. 2 ro.

Ibid., p. 211. 
describes it as "purely logical" and "subjective." So again, with a slight limitation, he says: "What may for the moment detain us, however, is a reference to the curiously nearly completely subjective character of the evidence for both the theory of descent and natural selection."

Why then this intolerance of others who from the very same scientific facts drew vastly different conclusions? How silly, above all, the attack upon Christianity and the blowing of Jericho trumpets, as if the strongholds of Faith must collapse at the din, when in reality no least truth of Christianity has been touched or embarrassed by any of the scientific facts hitherto discovered. Nor is there a shadow of fear or apprehension that any really established fact of science will ever in the slightest compromise the equally undeniable fact of the Divine Revelation. The Church, as in the outset has been stated, welcomes knowledge, science and investigation. She merely insists upon a careful distinction between fact and theory. Facts are unalterable, undeniable, more immovable than the rock-ribbed mountains; theories change like the clouds that cast their shadows in the valleys. They are often more finely spun than the fleeces of the summer sky. The theories of evolution, especially, have been as manifold and changeable as the colors of an autumn sunset, shot through with a thousand shifting hues that blaze s"Darwinism Today," p. 18. 
in their brief glory only to die down again to ashen gloom.

It is true that evolutionists have at times been exceedingly materialistic. Yet the facts themselves, of science, where there is a question not of preconceived prejudices or idle imaginings confused with realities, have not the slightest logical relation with the conclusions of materialism. This can perhaps best be made plain at the very outset by a very practical illustration.

Of all the branches of science biology can claim to be most intimately connected with the evidence on which materialistic evolution should be based. Yet in the case of the world's greatest biologists down to the twentieth century, we find that science has not in the least interfered with their religious convictions or impressed them with the need of accepting any form of materialism, whether ancient or modern. In gathering the names of the world's most eminent biologists, deemed worthy of mention in the eleventh edition of the "Encyclopedia Britannica," Professor Menge happily indicated the various beliefs of these men. ${ }^{\circ}$ Fifteen were Catholics, nineteen belonged to other Christian denominations, eight might be classed simply as "believers," six were vitalists, accepting an imminent vital principle which Christians would call a soul, and twentyseven only remained out of seventy-five, whose

"Edward J. Menge, "The Beginnings of Sciences," pp. 200, ff. 
religious convictions, if any, were nowhere indicated. Yet even of these latter no small number may well have been believers. Few probably would have hesitated to repeat in their own regard the statement made by Darwin, only three years before his death: "In my most extreme fluctuations I have never been an atheist in the sense of denying the existence of God." ?

Since materialistic evolution is the natural offspring of nineteenth century infidelity, and was indeed explicity mobilized and promoted for the rationalistic campaign against the Church by men like Haeckel, it is particularly interesting to note these results taken from the igro edition of the Encyclopedia, the very time when materialism still fatuously vaunted that it had displaced Christianity.

What is even more significant is the fact that of the eleven founders of the various biological divisions, all, with the single exception of Darwin, were positive believers. ${ }^{8}$ Among them Lamarck, the founder of modern evolution, to whose theories the twentieth century schools of evolution largely returned after the rejection of Darwinism, was a Catholic. So also were Malpighi, the founder of pathology; Schwann, the founder of the cell theory; Pasteur, the founder of bacteriology; and Johannes Müller, the eminent founder

7 "The Life and Letters of Charles Darwin," I, p. 274.

${ }^{8}$ Menge, op. cit., p. 207. 
of modern physiology. The latter was described by Huxley as "the greatest anatomist and physiologist among my contemporaries." 9 Perhaps the best known of all these, in a popular sense, was Louis Pasteur whose faith was splendidly vindicated in the remarkable letter written by $\mathrm{Mgr}$. Joseph Guillot. ${ }^{10}$ The fact, of course, that La"Hume," English Men of Letters, p. r35. Windle "Science
and Morals," p. 76 .
"The communication is of sufficient interest to be quoted here
in its entirety. It is taken from the St. Paul Catholic Bulletin:
"Some three years ago a letter was published from Detroit,
and made the rounds of the press of the country, in which it
was stated that Catholics had no claims on Pasteur, one of the
greatest men of the last century, that his religion was mere
Deism, and that he never was a practical member of Holy Church. At the time I sought authentic information in the matter. It is only of late, owing no doubt to the many cares of my correspondents, during the last dreadful few years, that I have received complete answers to my inquiries, and they may be summed up in these very striking facts written in a letter I have from the chancellor of the diocese of St. Claude. The territory of that diocese comprises the department of Jura, in which is situated the pretty little city of Arboy, where Louis Pasteur was born and raised, and where his remains are buried between those of his good Catholic father and mother. The chancellor writes: (1) Pasteur was always known here as a good Catholic. (2) Even in his busiest days, he never failed to take at Paris a night train that would bring him to Arboy on the morning of Corpus Christi, so that he could join the procession of the Blessed Sacrament. And he came again every year at the end of September, to be present at what is called here the vintage feast, when the first ripe grapes gathered are brought by the most notable Catholics to the parish Church, where they are blessed by the pastor. (3) A few years before his death, presiding at the commencement exercises of the College of Dole, in the same department, he pronounced before his young audience these beautiful words, which were then quoted and commented upon by the papers: "When one has studied much, he comes back to the faith of a Breton peasant: as to me, had I studied more, I would have the faith of a Breton peasant woman." (4) In April, I895, the year in which he died, he insisted on going, with his worthy wife, to receive his Easter 
marck and others are cited as Catholics does not imply a defense of all their statements from a Catholic point of view.

It is certainly remarkable, and it may possibly be considered astonishing by some, that almost one half of the illustrious number of the great modern pathfinders in the most modern of sciences. should be Catholics. Yet Catholicism, in particular, has by many been superficially believed to stand in conflict with science. It is interesting to note, in this same relation, that the Jesuits themselves have given to science a vigorous school of evolution at whose head stands the supreme authority on ant-life, the Rev. Erich Wasmann, S. J. The Catholic Church has often been described as "narrow." This is true in the same sense in which science and mathematics must always remain narrow. There can indeed be no disputing the verities of the multiplication table. A fact or truth, once clearly established, simply admits of no alternative; a theory may be freely questioned. Such is the only narrowness that Catholics themselves have ever experienced, in common

Communion in the parish church. (5) On Friday, September 25, the day of his death, he very piously received the last Sacraments from Father Richard, one of the assistant priests, and was able afterwards to have a lengthy conversation with Father Boulanger, a Dominican, who was the great man's confessor. I believe this will satisfy anyone, as a proof that Pasteur was a faithful child of the Church, and his example is another confirmation of the words of Pascal that 'a little knowledge estranges one from God, whilst great knowledge brings one nearer to God.'" 


\section{EVOLUTION AND SOCIAL PROGRESS}

with all sane scientists and mathematicians. Above all, Catholic scientists and investigators are carefully warned against putting forth as facts any statements of whose certainty sufficient proofs are wanting. Hence no better foundation for a scientific training can be conceived than that supplied by the Church.

Perhaps the greatest of all the names in the science of biology according to many of the leading scientists of the twentieth century was the Augustinian monk Johann Gregor Mendel. Not a few look upon his contributions to modern thought as the most important biological discoveries of the entire previous century. Castle rightly describes them as "the most original and instructive series of studies in heredity ever executed." 11 The edition of the "Enclopedia Brittannica" to which reference has been made, recognized this fact by assigning to him more space than was given to any other of the seventyfive most famous biologists of all time. Yet his tireless and amazing investigations into the mysteries of reproduction and heredity, where these could best be studied, in the life of plants, doubtless but strengthened and intensified his Catholic faith. He died as abbot.

Confining ourselves to a single branch of science, the one most intimately associated in the

${ }^{11}$ Menge, op. cit., p. 52. See in particular: Padberg and Muck. ermann, "Mendel und Mendelismus." 
minds of men with the theory of evolution, we have made plain how absurd was the statement of Huxley regarding evolution, that: "One of its greatest merits is that it occupies a position of complete and irreconcilable antagonism to that vigorous and consistent enemy of the highest intellectual, moral and social life of mankind-the Catholic Church." "He had devoted a few brief moments of a certain idle afternoon, as I recall it, to glancing at the voluminous tomes of the great Jesuit theologian Suarez, had dipped his little cockle-shell into that vasty sea of profound metaphysical lore with which he might well have buffeted for years, and forthwith believed he understood all the Catholic Church had to say on the subject of science. The fact was that he had merely confirmed his own complete ignorance of the matter. Others who have spoken with equal assurance can be found to have not even extended their own original researches so far as he.

Curiously enough, in this connection, it was Huxley himself who after a somewhat more thorough study of the Galileo case wrote to St. George Mivart: "I gave some attention to the case of Galileo when I was in Italy, and I arrived at the conclusion that the Pope and the College of Cardinals had rather the best of it." ${ }^{13}$

12 Thomas H. Huxley, "Darwiniana," p. 147.

13 "Life and Letters," II. p. Ir3. 
Catholics, on the other hand, freely acknowledge that here a palpable mistake was made by the ecclesiastical authorities in matters of science. But the one thing remarkable about the case, as Cardinal Newman long ago pointed out, is that it affords the professional enemies of the Church the one instance that can be cited by them out of centuries of incessant ecclesiastical relations with the various sciences. It needs but a glance at such works as those of Dr. Walsh to appreciate the incalculable assistance the Church has afforded to science. $^{14}$

Yet Huxley was not wrong in his conclusion. For although the fact was rightly stated by Galileo, his proofs were utterly inadequate. Many years indeed elapsed after his death before the first scientific evidence was offered for his views. The prison horrors, very imaginatively interwoven with this story to give it the proper human appeal, were, as we well know, the purest inventions. "The Papal power," wrote Professor Augustus de Morgan, a writer never suspected of Catholic proclivities, "must upon the whole have been moderately used in matters of philosophy, if we may judge by the great stress laid on this one case of Galileo. It is the standing proof that an authority which has lasted a thousand years was

\footnotetext{
${ }^{16}$ See in particular: Dr. James J. Walsh, "The Popes and Science."
} 
all the time occupied in checking the progress of thought (!) There are certainly one or two other instances, but those who make most of the outcry do not know them." 15

${ }^{15}$ Ibid., p. 16. 


\section{HAECKEL AND THE MONISTIC CREED}

T THEN Julian the Apostate, bent upon the destruction of the Church, forbade her to teach the sciences, St. Gregory of Nazianzen exclaimed: "Who could have put it in your mind to forbid us the sciences? There is nothing I hold dearer after the interests of heaven and the hopes of eternity. .. . It is right I should defend them with all my power of words and the fire of my heart." 1 Such today, such always, is the attitude of the Church towards science.

There is but one thing the Church fears, and that is ignorance. "More light," was Goethe's last word. It is the word ever upon the lips of the Church as she looks with compassion upon the darkness that encompasses the earth. She welcomes every discovery. She encourages every legitimate research. She rejoices in every fact and every truth, whether gathered from the longsealed pages of the earth's great volume, from the profundities of the mind of man, or from the Sphinx-like silences of nature. "Religion has no " "Disc. IV contra Jul." 
fear of science," Pope Pius X so emphatically said; "Christianity does not tremble before discussion, but before ignorance."

Faith itself rests upon a basis of the most exacting scientific knowledge and research. There is no difference between the test that the Catholic Church presupposes before her tenets can be accepted by the seeker for truth who comes to her from without the Fold, and that which the most rigid scientist can demand where there is question of ascertaining the facts and laws of nature. The Church indeed sets her light for the feet of science that by following her example it may never stumble in the dark. She does not rest satisfied with a conviction based upon even the strongest probability, but requires absolute certainty on the part of the prospective convert. Only when every slightest and most halting doubt regarding her own Divine foundation and her teaching authority has been finally removed from the mind can faith be said to begin, a faith, therefore, whose motives of credulity are as truly scientific as the belief of a Faraday or a Marconi in the most perfectly ascertained laws of nature, or in the truth that two and two are four. These facts the scientist questions no longer, as the Catholic no longer questions the Divine authority of the Church.

On this point we may once more be permitted to quote from another volume by Cardinal Mercier, 
than whom there has been no more truly independent mind in Europe. He well says :

Whatever superficial unbelievers who understand nothing of the certitude of our religious beliefs may say of it, it is undoubtedly true that, in proportion as the Christian's faith is sincere, in like measure is he or she free from the uncertainties that disturb the mind and paralyse the will.

The Catholic scientist is sure of the truth of his faith. Those who do not share his faith will perhaps say he is wrong. The fact remains that the Church is certain his faith does not deceive him, and that it cannot deceive him, and this certainty is fortified in proportion as his faith grows stronger. He is also certain, unquestionably certain, that the discovery of a new fact will never contradict his belief. Therefore the Christian scientist who is disturbed as to the eventual future of science is lacking either in faith or in scientific knowledge, or in both.

The unbeliever, on the contrary, who has founded his philosophical and religious theories on the shifting sands of personal speculation or human authority, has no guarantee that they will not be destroyed by the next discovery. If his theories are sincere, so will be his desire to confirm them, his zeal to protect them, and hence all the stronger will be for him the a priori element that troubles the serenity of the scientific mind. ${ }^{2}$

Here precisely has been the difficulty of the materialist in modern science, who has sought by every means in his power to confirm his preconceived idea that nature must be explained without God, and who too often has ruled out of court whatever evidence might conflict with these ideas, merely because it would render them untenable. The Catholic believer labors under no such difficulty. His mind is perfectly open to every evidence. He does not seek to controvert it or to

a "Modernism," pp. 
lessen by one iota its full significance and all that this may imply. He understands, like every true scientist, that new discoveries when ultimately confirmed by incontrovertible proof may refute the scientific theories to which he now adheres; but he knows, beyond the shadow of a doubt, that they will never conflict with one single truth of the Divine faith that is happily his within the Church. No man therefore can enter upon the work of scientific study and research with a more open mind than the Catholic scientist, who can have but one purpose in all his work: that the truth be most fully recorded, and that the often insignificant residue of fact be carefully discriminated from the endless welter of theory and hypothesis.

Nothing of course could be wider of the mark, as we have already shown, than the implication so common in materialistic literature that unbelievers have no philosophy to defend. Every one who thinks has his own system, as the great Cardinal just quoted rightly says, and we would not do them the injustice of holding that they never allow themselves the luxury of thought.

I have recently glanced through the sometimes melancholy and sometimes humorous reflections of the English thinker Harrison, who is intimately connected with the Positivist and Agnostic movement, latterly represented in England by Spencer, John Stuart Mill, Huxley and Lewes. All these men, he observes, had their own religion. Have they not even defined the Unknowable? ${ }^{8}$

${ }^{8}$ Ibid., p. 16. 
No creed therefore has ever been more dogmatic than that of materialism, precisely because it depended upon dogmatism alone for its acceptance. If ever a dogmatist existed it was the hierophant of modern materialism, Ernst Haeckel. Quite consistently he acclaimed himself the founder of a new "scientific" religion, which was established mainly as a denial of a personal God, and for a time even boasted of an ephemeral mone astery of Monistic monks-heaven save the mark! Such was Monism, the materialistic creed enthusiastically adopted by countless rationalists and Socialists throughout the world. To allay all fear of a religious bias in our estimate of the sage of Jena, it will suffice to quote here from the Manchester Guardian, whose religious and social views will not be held under suspicion of such prejudice even by the most ultra-radical. Appraising the life-work of Haeckel, it says:

Unlike Darwin, Haeckel entered into the field of theological controversy. Darwinism has had a profound and far-reaching influence upon ethics and religion, but so far as the master-mind was concerned it has worked by stealth and without any compact body of doctrine corresponding to the orthodoxy of the schools. Haeckel, on the other hand, drew out with uncompromising distinctness what he conceived to be the necessary results of his evolutionary teaching as a solvent of traditional theology. In his later years he was known chiefly as the ardent apostle of materialistic Monism as opposed to every form of spiritual religion or idealistic philosophy. He published "Das WeltRäthsel" in 1889 , and in spite of its severely technical qualities it passed rapidly through several editions. Under the direction 
of the Rationalist Press Association it was translated into English with the title "The Riddle of the Universe," and became at once the storm-centre of controversy. It was read eagerly by intelligent working men, and added fuel to their hostility to the churches. It was hailed as a new evangel by the earnest group led by Robert Blatchford and the Clarion newspaper." Sir Oliver Lodge wrote an able refutation from the scientific point of view in "Life and Matter," and many books and pamphlets in defence of religion testified to the strength of the impression which had been created.

The position of "The Riddle of the Universe" is frankly materialistic. Everything rests ultimately upon a purely physical basis. Psychology is only physiology under another name. Consciousness is a matter of physics and chemistry. Rigid determinism rules everywhere: "The freedom of the will is not an object for critical scientific inquiry at all, for it is a pure dogma, based on an illusion, and has no real existence." This sentence is a good illustration of Haeckel's attitude to every form of religious thought. His vehement dogmatism at first arrested attention and then began to excite misgiving. Incidentally "The Riddle of the Universe" contains an attack upon Christianity, but in the sphere of historical investigation Haeckel had no expert knowledge. The chapter on science and Christianity is an unfortunate illustra ion of the overruling by prejudice of a mind of great original power. It is the partisan performance of a pamphleteer for whom evidence has ceased to exist."

No one will wish to question his achievements as a scientist, but no one can deny his charlatanry as a philosopher or the brazenness with which he perpetrated his criminal frauds. ${ }^{7}$ His offenses against humanity, which far out-balanced his ser-

"Representing the extreme atheistic Socialism.

"The Catholic answer was given in "The Old Riddle and the Newest Answer," by Father John Gerard, S. J. (Longmans).

"Quoted in the Bombay Examiner, Sept. 27, 1919.

"See "Haeckel's Frauds and Forgeries," Assmuth and Hull. 


\section{4}

EVOLUTION AND SOCIAL PROGRESS

vices, were naturally condoned by those who saw in him the leader of modern atheism in its vain attempt to destroy Christianity. Though utterly ignorant of economics and sociology, he became the idol of anarchism and Socialism. In the Reichstag, September I6, I876, Bebel, the accredited spokesman of Socialism, said of him:

I believe that because of his ignorance of sociology Professor Haeckel, the out-spoken advocate of the Darwinian theory, had really no conception of the fact that Darwinism necessarily promotes Socialism, and that Socialism in turn must be in harmony with Darwinism if its aims are to be correct.

By "Darwinism" Bebel, in his obviously corresponding ignorance of science, understood materialistic evolution. What Bebel really meant to establish-and in this he was perfectly correctwas the intimate relation between irreligion and Socialism. From this point of view Haeckel became, together with Marx, the prophet of Socialism. Rationalism, on the other hand, delicately glossed over his failings. His substitutions of false plates to deceive his readers, and similar devices were thus, for example, euphemized, in the London Times: "He was not infrequently misled by the tendency to schematize and to generalize which he had crystallized in artistic rather than in scientific interpretation." 8 What a bewildering way of expressing the simple fact that he told a lie when it served his purpose, and was never

${ }^{8}$ August II, rgrg. 
ashamed of it.' After abolishing all human accountability by his supposed abolition of a personal God, there could be for Haeckel no immorality in such an act. It caused him neither any visible qualms of conscience, nor the slightest embarrassment to admit the falsehood when detected.

"Evolution from moneron to man," became the cry of the new "enlightenment." It was reëchoed from press and platform. It was made the creed of the schools. Acceptance of it was the hall-mark of intelligence. The literature of sociology is almost entirely based upon it. What was the attitude of the Catholic Church?

Evolution was for her an old familiar theme. She had weighed it unafraid centuries before, and was not to be perturbed by it now. She merely asked for facts and proofs. It has always been her way. Yet nothing could have been more tantalizing than this to the modern theorist, who had leaped to rash conclusions and now imperatively demanded that they must be accepted forthwith, and on his very word. He was the more insistent in that proofs were wholly wanting. But the Church was not concerned about the question as a scientific controversy, though she was then as always glad to accept any evidence. Her sole duty was to preserve the world from religious error and the menace that this implied to morality, to liberty and to every form of human welfare. 


\section{6}

The discussion of evolution, within the realm of scientific fact or of probable theory, was a wholesome activity of the human mind. But the dogmatic assertion of statements that admitted of no proof, that not seldom stood in direct contradiction to right reason itself, and that originally were proposed with the avowed purpose of destroying all belief in the existence of a Creator, could not be passed over by her in silence. Such were both the dogma of materialistic evolution and the equally impossible creed of Monism which Haeckel set out to preach, finding numberless ready apostles in the Socialistic and rationalistic schools who had merely waited for a leader. Haeckel was the man equipped for this positionthe Mahommed of Jena. No religious fanaticism of Parsee, Brahmin or turbaned Moor ever devoted itself with a more blind zeal to the promotion of a false creed. Monon was god and Haeckel its prophet. Yet few really knew what it all meant. Here, in brief, is Haeckel's own definition of the new philosophy and religion:

The Monistic or mechanical philosophy affirms that all the phenomena of human life and of the rest of nature are ruled by fixed and unalterable laws; that there is everywhere a necessary causal connection of phenomena; and that, therefore, the whole knowable universe is a harmonious unity, a "monon."

It says, further, that all phenomena are due solely to mechanical or efficient causes, not to final causes. It does not admit free will in the ordinary sense of the word. In the light of the Monistic philosophy the phenomena that we are wont to regard as the freest and most independent, the ex- 
pressions of the human will, are subject just as much to rigid laws as any other natural phenomena. As a matter of fact, impartial and thorough examination of our "free" volitions shows that they are never really free, but always determined by antecedent factors that can be traced to either heredity or adaptation. We cannot, therefore, admit the conventional distinction between nature and spirit. There is spirit everywhere in nature, and we know of no spirit outside of nature. Hence, also, the common antithesis of natural science and mental or moral science in untenable. Every science, as such, is both natural and mental. That is a firm principle of Monism, which on its religious side we may also denominate Pantheism. Man is not above, but in, nature... The evolution of man is directed by the same "eternal, iron laws" as the development of any other body. These laws always lead us back to the same simple principles, the elementary principles of physics and chemistry. The various phenomena of nature differ in the degree of complexity only in which the different forces work together. ${ }^{\circ}$

That, incredible as it seems, became the doctrine of our schools, academies and universities. Yet Haeckel did not pause here. As a substitute for the opening words of the Bible: "In the beginning God created heaven and earth," he offered with dogmatic certitude, though incapable of even the shadow of proof, and philosophically impossible, the following three opening clauses of his creed, to which the learned nineteenth-century dons subscribed with a species of blind faith never asked of Christian man or woman, and for which they expected an equal amount of credulity on the part of their docile pupils:

" "The Evolution of Man." 
(I) The universe, or the cosmos, is eternal, infinite, and illimitable. (2) Its substance, with its two attributes-matter and energy-fills infinite space, and is in eternal motion. (3) This motion runs on through infinite time as an unbroken development, with a periodic change from life to death, from evolution to devolution. ${ }^{10}$

These statements, as every reasonable man must admit, can never possibly be proved. They are bold assertions in defiance of reason. The faith with which they were to be accepted differed essentially from the faith of the Christian believer. This, as St. Thomas says, has a fourfold relation to reason: (I) it presupposes the operations of reason on the motives of credibility for which we believe; (2) it is rendered intrinsically credible by reason; (3) it is illustrated by reason; (4) it is finally defended by reason against the sophisms of false philosophy. ${ }^{11}$

On Haeckel's word, rationalists and Socialists without number accepted the infinity of matter and of ether, the extension of both through infinite space, and the no less absurd dogma that made of them both living and eternal beings. "Surely not science," as Wallace, the English Darwinian exponent, exclaimed in reference to these Haeckelian dogmas, "but very poor philosophy!"

Even Haeckel's scientific deceptions, to which we have alluded, such as the plain fact that he had used the same photographic plate for dif-

10 "The Riddle of the Universe," p. I3.

"Summarized from the Month, Dec., 1917. 
ferent objects to prove their close similarity to one another, could not shake this superstition. A scratch on the plate had revealed the imposition practised by him in the name of science. Yet this was not the worst of his deceptions and of his presentations of pure assumptions for "undoubted" facts. ${ }^{12}$ But nothing could disturb the faith of his enthusiastic apostles. Had he not created the Monistic god, and did not this suffice? Monism was the religion of Socialism, as the followers of Marx repeatedly assured us. Monism was the favorite dogma of rationalistic scientists. Monism was the humanitarian creed! of countless philanthropists, uplifters and materialistic sociologists. It affirmed the identity of God and the material world, beyond which nothing was to be admitted. It denied the personal existence of a Creator and ascribed His attributes to matter. Man was nothing more than the developed ape. What a glorious emancipation for brute passion, brute greed and brute force! Anarchist and Bolshevik seized upon this doctrine no less than the modern profiteer and sensualist. Haeckel himself described his materialistic evolutionary theories as "Monistic heavy artillery" directed against Christianity. His guns have been battered to pieces, but the Cross of the Church of Christ stands forth more resplendent than ever

"Erich Wasmann, S. J., "Modern Biology and the Theory of Evolution," pp. 213, ff. 
against the blue of God's unclouded heaven. Yet the evil he has done lives after him.

Self-existent matter and a self-propelling force to set it in motion, such as Haeckel was obliged to postulate in his new religion, are a contradiction and an absurdity from the view-point of philosophy. Only a simple, infinitely perfect being can of its very nature be self-existent. So too "matter" and "eternity" are contradictory terms. Only a being not subject to change and having in itself the reason for its existence can be eternal. It is a question we cannot enter upon here, but enough has been said to show how completely it lies beyond the range of physical and chemical science. To sum up in the words of Wasmann:

"An explanation of the first appearance of matter and of the first appearance of the laws governing it, is not possible, if we understand thereby an explanation given by natural science; for this starts with the assumption that matter and its laws exist. But in the philosophical sense an explanation of creation is possible. Philosophy shows us plainly that matter is finite; the conception of matter and its properties involves its being essentially limited and finite. It is therefore inherent in its nature that it cannot of itself have existed from all eternity, for that is possible only in the case of a being of infinite perfection, an ens $a s e$, as ancient philosophy and theology worded it. 
"This being we call the personal Creator, the being existing of Himself for all eternity, and having the reason of His existence in Himself. Precisely because $\mathrm{He}$ has the reason of His existence in Himself, He was able out of the abundance of His own infinite perfection to evoke the finite out of nothingness, and this is what we call 'creation.' Creation was not necessary; it was a free act of God." 13

That the truth of Creation does not conflict with any sane theory of evolution needs hardly be pointed out here. Evolution as a scientific hypothesis, the "Catholic Encyclopedia" clearly and definitely states: "is in perfect agreement with the Christian conception of the universe; for the Scripture does not tell us in what form the present species of plants and of animals were originally created by God." ${ }^{14}$ Certain limits, however, must be placed to this theory, as reason itself and true science demand.

On these subjects more shall be said hereafter, as also on certain evolutionary and biogenetic statements, distilled in the alembic of Haeckel's imagination and in no sense the result of scientific investigation. Together with Monism they are still retained by many of Haeckel's belated devotees, as part of that glorified superstition which long held in bondage a great part of the

\footnotetext{
13 "The Problem of Evolution," p. 213.

${ }^{14}$ Article on "Evolution."
} 
scientific world. It is in fact no exaggeration to say that science was made the breeding ground of the worst and most debasing, as well as the most disastrous of modern superstitions: materialistic evolution.

Absurd as is the theory of blind chance, Monism, identifying God with the material universe, has rightly been defined as merely "a poor medley of irreconcilable and inexplicable contradictions." Conceived as the most perfect being, its god must develop with the world and depends for his existence, as Wasmann well remarked, on the existence of every midge and fly in which he continues his course of evolution. "To have created such a god is the achievement of modern lack of thought and not of modern science. On the contrary the recognition of a personal God, who in virtue of the fulness of His own being created the world out of nothing, is still demanded by sound human understanding, and is therefore a true postulate of science." How this doctrine can be retained with all sane theories of Evolution shall be made plain in the following chapters. 


\section{THE ORIGIN OF LIFE}

A TIME existed when there was no life upon this earth. All scientists fully agree upon this fact. The intense heat of the glowing planet in its first stages would have rendered life impossible. How then did the earliest organisms come into being? Mere inorganic matter cannot have been the cause, for spontaneous generation is now scientifically rejected. Science can enlighten us no further.

Philosophy now enters on the scene and tells us that since no cause of life existed upon this earth we must look for one from without. The explanation that the first cell of life was wafted to us from some meteoric body, hurling along its path through space, is no solution, since it merely transfers the difficulty from the planetary earth to the roving meteor. That body, too, had passed through the same primordial stages. Yet a cause there must have been, and this can therefore be looked for only from without this world, in the sense that it was not identical with it, as pantheism or Monism postulate.

This cause, again, must of necessity have been 
a being gifted with intelligence. In ordinary life no man would question that postulate, even if reference were made to the origin of such relatively simple matters as a reliable time-piece or a perfectly ground 'lens. For any one to attribute the formation of these objects to blind chance would be considered reason sufficient, on the part of anxious friends, to call at once for the assistance of the nearest alienist. There is no escape from the dilemma that life as well as matter can owe its origin to an intelligent cause only - simple, necessary and self-existent of its very nature, such as God is and matter cannot be-or else to blind chance. Whatever circumlocutions may be used, it is not possible to escape this inevitable conclusion. But to ascribe to blind chance the wonderful life of the universe, is, as Darwin rightly says, an assertion "which our minds refuse to accept." 1 To seek to shift the difficulty by taking recourse to evolution for the cause of these inexplicable developments, is but to make still greater demands upon the surpassing intelligence and power of the being that conceived such laws and was able to impose them upon nature. To quote the famous passage of Wasmann :

If we assume that God is the Creator of all things, and that the world created by Him was evolved independently and automatically, we have actually a greater idea of God than

1 "The Descent of Man," p. 613. (Appleton, 1896.). 
if we regarded $\mathrm{Him}$ as constantly interfering with the working of the laws of nature. Let us imagine two billiard players, each having a hundred balls to direct. The one needs a hundred strokes in order to accomplish this end, the other with one stroke sets all the balls in motion, as he wills. The latter is undoubtedly the more skilful player. St. Thomas Aquinas stated long ago that the force of any cause was the greater, the further its action extended. God does not interfere directly in the natural order where $\mathrm{He}$ can work through natural causes. This is by no means a new principle, but a very old one, and it shows us that the theory of evolution, as a scientific hypothesis and theory, so far as it can be really proved, is perfectly compatible with the Christian theory of the origin of things.

According to this view, the evolution of the organic world is but a little line in the millions of pages contained in the Book of Evolution of the whole universe, on the title page of which still stands written in indelible letters: "In the beginning God created heaven and earth." 2

There are, however, certain stages at which Wasmann himself shows that a special act of creation is demanded by philosophy. Such is first the original creation of matter, secondly the creation of life, and thirdly the creation of the mind of man, of his intelligent soul. His statement, however, must not be taken to imply that these three were in fact the only direct creative acts of God in the production of the universe with all that it contains. Neither science nor theology is empowered to tell us how many such actions may have taken place. The data are contained neither in the book of nature nor in the Holy Scripture. There is, however, one remarkable 2"The Problem of Evolution," pp. 19, 20. 
scriptural fact to which we should not fail to call attention and that is that the use of the word bara, which "always means the production of something totally new, and in an original manner, or what we call 'creation out of nothing," " occurs in three places only in the Genesis account:

Verse I. "In the beginning God created heaven and earth." The creation of the heavens and the earth as a whole.

Verse 2r. "And God created great whales and every living and moving creature" (i. e., the starting point of animal life, which could not evolve of itself out of lifeless matter).

Verse 27. "And God created man to his own image and likeness" ( $i$. $e$., the origin of the spiritual soul of man, which could not evolve out of mere animal life). ${ }^{3}$

In other places the words used are: asah, to make; yasar, to form, and banah, to build. Thus the body of man was not directly created but formed out of the dust of the earth-whether immediately or through evolution from some lower forms we shall consider later. But the existence of the intelligent soul can be due only to the distinctive action described by the word bara, for: "Interpreters understand this image and likeness (of God) to consist in the mental qualities of intellect and free will, which are the properties of a rational and responsible being." 4 Again, however, we must not leap to the rash conclusion that therefore it follows that these three

"The Bombay Examiner," Feb. 28, r920. Zahm, "Bible Science and Faith," p. 54 .

"Ibid., March 20, 9220. 
were necessarily the only direct creative acts, and that all other created beings are the result of evolution, directed by laws which the Creator, of course, would have placed in nature.

Orthodox commentators, as Father Hull quite rightly states, are prepared to accept evolution as soon as it can be verified and to whatever extent it can be verified, but the following principles, he adds, will still remain axiomatic and untouched by science, to whose sphere they in no sense belong:

(x) That even if the whole formation of the physical world was achieved by a process of evolution according to natural laws, still the elements of the universe were originally created by God in their totality, and had a beginning at some point of time measurable backwards from the present.

(2) That all the laws of nature by which evolution took place were imprinted on these elements by God, whose mind first conceived the whole scheme of evolution, and then arranged the laws in such a way that they would issue in the foreseen realization of His plan.

(3) That life-even plant life-belongs to an order higher than that of matter and could not be produced by any mere combination of material particles arranged by mechanical forces; and therefore the first beginnings of plant life must have been directly introduced into lifeless matter, at least in a germinal form, superior in nature to anything merely electric, atomic or molecular.

(4) That as the animals, again, belong to an order essentially superior to mere plant life, the same necessity arises for a direct creative action depositing in the water, or in the land, the first germs of animal life.

(5) As the rational soul of man is also of an essentially higher order than animal life, this again postulates a direct act of creation on the part of God to bring the first man into 
existence; and by a philosophical corollary, the same direct act of creation must be performed to produce the soul of each subsequent human being, while the body is being produced by natural generation.

It can be seen that where Father Hull demands a twofold specific act of creation, respectively, in regard to plant and animal life, Wasmann, without denying this principle, is content with postulating, for the simplification of his argument, at least one single creative act for life in general. Aside from this slight distinction there is substantial agreement on all these points, which philosophy lays down as incontrovertible according to the principles of sound thought and logic, without making any reference here to the teaching of religion and the Scriptures.

As in regard to the origin of matter, so in regard to the origin of life, science has nothing to teach us. It is in no sense any part of the scientific theory of evolution to explain the origin of life. No scientific data exist or can ever be obtained which will give us the slightest aid towards the solution of the question: "How did the first organisms come into being?" It is a question purely philosophical, if for the present we prescind from its religious aspects. Science merely informs us, according to the common consent of practically all authorities, that of the two possible ways, spontaneous generation or else a

'Ibid., March 13, 1920. 
creative act, by one or other of which we must account for the origin of life, spontaneous generation must be entirely rejected. Nothing therefore remains but the creative act. Dogmatic statements about the materialistic evolution of life, found in certain writers, are consequently purely gratuitous assertions. The explanations given are empty platitudes wrapped up in high-sounding but meaningless scientific phraseology.

In 1892 Schaaffhausen announced that a combination of water, air and various minerals had produced a Protococcus, under the influence of light and heat, and that this had turned into the Protococcus viridis. But Schaaffhausen never produced a living cell to prove his theory. The ill-starred Bathybius Haeckelii and the same author's Autoplasson have never yet emerged from a test tube, and never will. Maggi discovered that the primary life-substance was Glia. ${ }^{6}$ But all these imaginary original life-forms belong to exactly the same class as Goethe's homunculus, the ungrateful little imp who leaped from the scientists' test-tube only to scoff at his enraptured maker. They are inventions that belong to the order of Grimm's "Fairy Tales," but must not be taken seriously as scientific discoveries. Schwann gave us his cytoblastema and Robin conceived his blastem, and we are just as wise as before, though we smile a gentle smile when Herbert 'Wasmann, "Modern Biology," pp. 193-206. 
Spencer tells us: "At a remote period in the past, when the temperature of the earth's surface was much higher than at present, and other physical conditions were unlike those we know, inorganic matter, through successive complications, gave origin to organic matter." 7

Since the theory of spontaneous generation is entirely rejected by modern scientists, it follows that the materialistic explanation of the beginning of life, like the same explanation for the existence of matter and motion, can be accepted only on the supposition of a blind act of faith. But, again, it is faith which must not for a moment be confounded with the faith of the Christian. The non-Catholic adult, as we have already sufficiently shown, cannot accept the Catholic Church as the Divine Teacher, appointed by Our Lord to certify mankind as to the truths of the Divine Revelation, until he has absolute proof that the Catholic Church has indeed the needed credentials of such a Divine teacher. ${ }^{8}$ No such proofs can ever be offered as motives of credibility for those who are bidden to make an act of faith in the assertions of materialistic science. This is particularly true in the important question of the origin of life. In the presence of scientific men Huxley himself was bound implicitly to admit the untenable position of dogmatic ma-

"Nineteenth Century, May, 1886.

${ }^{8}$ The Month, Dec., 1917. 
terialism. "Looking back," he said, "through the prodigious vista of the past, I find no record of the commencement of life, and therefore I am devoid of any means of forming a definite conclusion as to the conditions of its appearance." 9

Science, on the admission he is forced to make in common with every scientist, has no data, no evidence whatsoever to explain the origin of life. Why then the bold assertion, made in the name of science, of the truth of materialistic evolution and the equally bold denial of a Creator? Huxley asked of the world neither more nor less than, in his own express words, an act of "philosophic faith." On this alone, as he admitted, his own opinion was grounded, and not on any scientific facts, no matter how tenuous. Plainly he wrote:

If it were given me to look beyond the abyss of geologically recorded time to the still more remote period when the earth was passing through physical and chemical conditions, which it can no more see again than a man can recall his infancy, I should expect to be a witness of the evolution of living protoplasm from not-living matter. I should expect to see it appear under forms of great simplicity, endowed, like existing fungi, with the power of determining the formation of new protoplasm from such matters as ammonium carbonates, oxalates and tartrates, alkaline and earthy phosphates, and water, without the aid of light. That is the expectation to which analogical reasoning leads me; but I beg you once more to recollect that $I$ have no right to call my opinion anything but an act of philosophical faith. ${ }^{10}$

" "Biogenesis and Abiogenesis." Presidential Address delivered before the Brit. Assoc. Adv. Science, 1870.

${ }^{10}$ Ibid. 
He dares not even call it "belief," he cautiously adds, because this implies "strong foundations," such as he admits are absolutely wanting for his conclusions. In brief, neither Darwin, nor Huxley, nor Haeckel, nor any other scientist has offered, or ever will be able to offer any explanation regarding the origin of life. Should this last statement seem too sweeping in its generality, it will be well to note that it embodies what may almost be called the unanimous consent of the great modern scientists upon this matter. After presenting an exposition of the most "scientific" theories upon the origin of life, including the tentative opinions of men like Troland, Allen, Moore and Osborn, Professor Woodruff offers the following summary:

All will undoubtedly admit that we are at the present time utterly unable to give an adequate explanation of the fundamental life processes in terms of physics and chemistry. Whether we shall ever be able to do so is unprofitable to speculate about, though certainly the twentieth century finds relatively few representative scientists who really expect a scientific explanation of life ever to be attained or who expect that protoplasm will ever be artificially synthesized. ${ }^{11}$

The very existence and nature of life, in other words, remain a mystery to science. Much less can it ever solve the problem of the origin of life, unless it admits the only solution that it is rationally possible to offer at this point, and that ${ }^{11}$ "The Evolution of the Earth and Its Inhabitants," edited by
R. S. Lull, p. 95. 
is a creative act. No one surely can speak with more authority upon this point, and with less theological bias, than the great biologist Reinke. His final word, that has often been quoted, may here well be called to mind again:

If we assume at all that living creatures were once formed out of inorganic matter, then, so far as I can see, the theory of creation is the only one which satisfies the demands of logic and causality, and so satisfies the demands of reasonable scientific research. ${ }^{13}$

It is good to read straightforward, honest words like these. Such too was the import of Lord Kelvin's famous avowal, thus reported on the occasion in the London Times: "He could not say that with regard to the origin of life science neither affirmed nor denied creative power. Science positively affirmed creative power." 13

The entire question, we repeat, really lies outside and beyond the realm of science. "All that we can say of it," as Professor Lull of Yale correctly states concerning the origin of life, so far as science can testify at all, "is that in the fullness of time, when the earth had, in the course of its physical evolution, become adapted as the abode of life, living substance came into being." 14 How it came into being, by a creative act or not, unaided science can never say. Metaphysics and religion here come to its assistance and proclaim

\footnotetext{
12 "Einleitung in die theoretische Biologie," p. 559.

${ }^{13}$ Times, May 2, 1903.

${ }^{14} \mathrm{Op}$. cit., p. 112 .
} 
the need of a Creator God. From Sir Isaac Newton to the present hour a long list of the most famous scientists, French, English, Italian, German, American, or of whatever nationality we please to mention, might here be enumerated who with Sir William Steward clearly recognize the supreme truth that: "All knowledge must lead up to one great result: that of an intelligent recognition of the Creator in His works."

Modern biologists, Lord Kelvin said in the speech already quoted, are coming once more to a "firm acceptance of a vital principle." They are returning, by many and devious ways, to the old truth taught all these years within the Christian schools. But they are still balking at a word and prefer to call a "vital principle" what we know by its Christian name, a "soul."

They only know God in His works, but they are absolutely forced by science to admit and to believe, with utter confidence, in a directive power, in an influence other than physical, dynamic and electrical forces. Cicero denied that these [the living beings about us] could have come into existence by a fortuitous concourse of atoms. There is nothing between absolute scientific belief in creative power and the acceptance of the theory of a fortuitous concourse of atoms. Is there anything so absurd as to believe that a number of atoms by falling together of their own accord can make a sprig of moss, a microbe, a living animal? People think that, given a million of years, these might come to pass. But they cannot think that a million of millions of millions of years could give them unaided a beautiful world like ours. ${ }^{15}$

${ }^{15}$ Times, 1. c. For clearness' sake the liberty has been taken here of transposing the reporter's indirect discourse into the 
Darwin himself, in his very last volume, in spite of his untenable conclusions regarding the origin of man, felt bound to confess no less. There is no solution for the problem of the origin of life except to acknowledge an ordained purpose, which necessarily postulates a directive and intelligent cause. This much even the most degraded savage, grovelling in fear before his totem of wood or idol of stone, has been able to perceive. However superstitious his form of worship, his act implies a recognition of the great laws of cause and effect, though erroneously applied. With a glimmer at least of intelligence and a memory of better things, he blunderingly seeks to express the same truth that Darwin protested he had never denied, that nature postulates an intelligent maker, that its wonderful laws, doubly wonderful on the hypothesis of evolution, presuppose of necessity a giver of those laws. This even Plate, the Monist, could not but confess in his Berlin discussion: "Personally I always maintain that, if there are laws of nature, it is only logical to admit a law-giver." 16

To conceive of this giver of nature's laws, this great originator of life, as a mere pantheistic force, is nugatory and unworthy of a thinking

direct language of the speech. We have deleted an adjective that Lord Kelvin, in a letter to the Times, May 4, 1903, desired should be dropped, thus showing his careful revision of the text.

${ }^{10}$ Wasmann, "The Problem of Evolution," pp. 108, ff. 
being. The Solonic legislation is inconceivable without admitting the mind of a true, personal legislator, such as we know the Athenian statesman to have been who formulated it. The clock upon the wall, that is ticking away the minutes and hours, is equally inconceivable as the work of an impersonal craftsman. Much more then must the origin of all living beings render imperative our candid admission of the existence of a personal Creator. Looking upon the blade of grass, the lowliest of living things, that God has multiplied a million-fold to spread for a carpet beneath the feet of man, the poet Francis Thompson broke out in the ardent exclamation:

Impenetrable fool

Is he thou canst not school

To the humility

By which the angels see.

Wonders enough can be found in that blade of living green to confute all the follies of atheism. How could stumbling chance, or an evolution not directed by the intelligence of a wise Creator, have ever produced the marvels of life contained in even a single one of all the invisible, multitudinous cells in that tiny blade of living matter, whose "fine mouths" all shout scorn on "dull-eyed doubt"?

If this is the undoubted conclusion we must draw from the humblest of vegetative forms, the same follows even more clearly from the sentient 
creatures about us. Take but the exampse of so commonplace a creature as the wasp. In his book, "The Hunting Wasp," published in an English translation, the great Catholic scientist, J. Henri Fabre, shows how the social wasp, in providing food for her young, skilfully paralyzes the grey worm by selecting about nine out of an indefinite number of points into which her stiletto must be thrust to secure her prey. He then makes plain the absurdity of postulating that such mastery could be acquired by chance and handed down by heredity. The credulity required for the acceptance of such a statement has nevertheless been made a fundamental postulate of our modern popular science. The wasp, sanely observes Fabre, excels in her art because she is born to follow it, is endowed with the tools and with the knack of using them.

And this gift is original, perfect from the outset: the past has added nothing to it. As it was, so it is and will be. If you see in it naught but an acquired habit, which heredity hands down and improves, at least explain to us why man, who represents the highest stage in the evolution of your primitive plasma, is deprived of the like privilege. What an immense advantage it would be to humanity if we were less liable to see the worker succeeded by the idler, the man of talent by the idiot! Ah, why has not protoplasm, evolving by its own energy from one being into another, reserved until it came to us a little of that wonderful power which it has bestowed so lavishly upon the insect! The answer is that apparently, in this world, cellular evolution is not everything.

For these among many other reasons, I reject the modern theory of instinct. I see in it no more than an ingenious game 
in which the armchair naturalist, the man who shapes the world according to his whim, is able to take delight, but in which the observer, the man grappling with reality, fails to find a serious explanation of anything whatsoever that he sees. In my own surroundings, I notice that those who are most positive in the matter of these difficult questions are those who have seen the least. If they have seen nothing at all they go to the length of rashness.

It is now suggested by representative scientists that many of the generalizations which for a long time have been part of the popular scientific creed, indiscriminately accepted by the unwary, would never have been formulated had the works of Fabre been better known.

Shall we weep or smile at the wiseacre wisdom of the Spencerian materialist who but yesterday announced, in words full of sound and fury, but signifying nothing, that: "Life is merely a name for the sum-total of the physico-chemical properties of protoplasm." 17 Pray, and what archangel told him that?

Even among those who hesitate to acknowledge a Creator the theory of vitalism, i.e., of an imminent life-principle, a soul, as we have always been accustomed to call it, is rapidly replacing the obsolete theory that there is nothing but physics and chemistry in the world, and that life, in plant, brute and man, is merely the result of mechanical action, propelled by a force God knows from where. This is the causo-mechanical theory, still

${ }^{17}$ Hugh Elliott, "Modern Science and Materialism," p. 94. 
common enough in our schools of a supposed higher learning.

Since scientists can no longer, without committing themselves to the most patent absurdities, deny the existence of a soul, they seek to gloss over the dreadful fact by calling it strange names in Greek: "biotic energy," "entelechy," "bathmic force," "genetic energy," and what not. By this they mean, in man for instance, that lifeprinciple which Christians call a human soul.

Causo-mechanism, the purely materialistic concept of life, which sees in every living cell merely a machine driven by some unknown force, carefully separated from the idea of any Divine and intelligent agent who might have brought it into being and is now directing it, reminds us of the clown who, as the story was told to me, appeared on the stage with a little trained automobile, that followed him about, and leaped upon his knee, and was delighted to be fondled by its master's hand, to the huge amusement of the children, young and old.

It was all, of course, merely a clever mechanical device, as everybody knew. But when our scientists can give to us an automobile that of itself, without any mechanical help, can perform all these tricks; whose motor has the power to convert the gasoline, with which it is daily fed, into glass for the lamp, oil for the wick, rubber for the tires, iron for the wheels, and metal of whatever kind for the rest of the complicated mechan- 
ism of the machine, which within every seven years or so completely renews itself; and which, to perpetuate its kind, crowds the floor-space of its master's garage with a strong and vigorous progeny of young automobiles that can in time replace it, when it at last must share the fate of all things earthly - why then, and not till then, will there be reason for giving some consideration to the materialistic explanation of life, to the causo-mechanical theory of learned university dons. Then at last we might believe that causomechanism is an explanation of the even far more wonderful vital operations that take place in the human organism.

But even all this would not be sufficient. That the argument of the materialists may be made convincing, it is necessary that they show us such a machine which was due to purest chance, which had no designer to plan it and no mechanician to make it, which just happened, no one knows how. When all this has come to pass, then and not till then it is time to consider whether this far more marvelous human machine, that converts the selfsame mother's milk into the eye that sees, the ear that hears, the little rosy fingers that can close so tightly on everything within their grasp, and all that makes up, in its thousandfold variety, the human body; whether this same wonderful machine that repairs itself, and renews itself, and 
reproduces itself, can have come into being without a Designer, without a Maker, without a Creator. While finite things, as we clearly know, must be dependent upon external causes, $\mathrm{He}$ alone of His very essence must be self-existent, as $\mathrm{He}$ is immaterial, infinite, eternal. Such is the God who has spoken through the prophets, who has manifested Himself in miraculous ways that any one can historically investigate, and who has lovingly taught us through His Christ and through His Church.

How, in fine, the world of science is gradually approaching the Catholic standpoint may be judged from the concluding words of the article on "Evolution" in "The Encyclopedia Americana," written by Kellogg himself. He there describes the position of Davenport, in regard to the causes and fundamental, control of evolution, as "essentially like Nägeli's vitalistic theory of evolution from within, by virtue of a perfecting or progressive tendency." This, he adds, "is an idea that goes back to Aristotle and includes Huxley and Bergson in its roll of adherents. In other words the most modern theory in explanation of evolution is essentially both anti-Lamarckian and anti-Darwinian, and allies itself with that type of explanation which may be called orthogenetic and vitalistic." 18

18 "Encyclopedia Americana," ed. rgrg. 


\section{DARWIN AND DARWINISM}

U

PON comparing the scientific proofs for the probability of the theory of evolution, we find that they grow the more numerous and weighty, the smaller the circle of forms under consideration; but become weaker and weaker if we include a greater number of forms, such as are comprised in a class or in a sub-kingdom. There is in fact no evidence whatever for the common descent of all plants and animals from a single primitive organism. Hence the greater number of botanists and zoologists regard a polygenetic evolution [i.e., from various primitive organisms] as much more acceptable than a monogenetic [from a single form]." Such is the accurate and scientific summary of our evolutionary knowledge as presented in the article on "Evolution," in the "Catholic Encyclopedia." It agrees with what has already been stated. How little reason, consequently, there can possibly be for dogmatism on this subject is now apparent. But the briefest outline of the history of evo- 
luetonary doctrine will make this even more evident.

Evolution is an ancient theory. Its modern renaissance, with which alone we are here concerned, was due in the first place to Lamarck, just half a century before the first edition of Darwin's "Origin of Species" was published. Jean Lamarck appeared before the world in 1809 with his "Philosophie Zoologique," in which he ascribed the evolution of species to the use or disuse of the various organs. His doctrine essentially implied the possibility of the transmission of acquired properties by the individual to his descendants. Darwin, fifty years later, was not to disregard this theory, but merely assigned greater importance to his own specific doctrine of natural selection. Hardly another fifty years elapsed and Darwin's fading star was to be again outshone by the reappearance of the Lamarckian somet, under a new form and under the new name of Neo-Lamarckianism. Sir Bertram Windle offers a very apposite illustration of the difference between Lamarck's and Darwin's theories in the case of the giraffe as explained according to their respective views:

The giraffe is provided with an extraordinary long neck and very tall forelegs. These he acquired, according to Lamarck's view, by constantly stretching after the foliage of trees, on which he feeds, and by ever reaching after higher and yet higher boughs. According to the Darwinian view certain giraffes were by reason of causes inherent in the embryo pro- 
vided with somewhat longer necks than their fellows. In time of stress these giraffes could get food where others could not. Hence they survived, and their progeny, also long-necked, gave rise to animals with still further development in the same direction. ${ }^{1}$

Neo-Lamarckians hold that new habits will produce new organs. Thus, rejecting Darwin's doctrine of selection as applied to this same interesting specimen at sight of which the clown protested there was no such creature, Cunningham asks how the horns of the giraffe could have been produced by this method, and then suggests his own neo-Lamarckian explanation: "What then caused such excrescences to appear in the ancestors of the horned ruminants? Butting with the forehead would produce them, and no other cause can be suggested that would." 2 But enough said, though we may mention here with that Darwinian champion, August Weismann, that there is no evidence that acquired characteristics are ever transmitted. So we leave these contending evolutionists to their own struggle, like two stags with inter-locked antlers.

The theory of Lamarck was championed in the lists by the two St. Hilaires, Etienne and Isidore Geoffroy. A series of sharp conflicts between these early evolutionists and the great scientist Cuvier now took place, the latter stanchly defend-

1 "A Century of Scientific Thought," pp. 68, 69 .

"Cunningham's Transl. of Eimer's "Organic Evolution," Preface; Windle, Ibid. 
ing the permanence of species. The struggle, in which the members of the French Academy participated, ended in the complete discomfiture of the upholders of evolution and the triumph of Cuvier's opinions. Lamarck himself died in poverty and neglect. Such was the first act of this modern drama.

With the appearance of the "Origin of Species" the curtain rose again, but this time upon a new conflict. Its central figure was Charles Darwin. Not now about evolution only did the battle royal develop, but largely about the theory of "natural selection," which alone constitutes Darwinism, in the proper sense of that much-misused word. It is Darwin's main original contribution to science. But before the close of the nineteenth century that doctrine, too, had already met with serious reverses.

There was no question indeed of abandoning the theory of evolution, whose existence is entirely independent of the acceptance or rejection of Darwinism, but merely of gradually relegating to a very subordinate position the doctrine of natural selection, particularly in its extreme acceptation. The followers of Darwin, in their turn, rapidly fell away from his standard, though his name was wildly used as a battle-cry for evolutionary doctrines with which he never had the slightest sympathy. We have heard Bebel, like countless Socialists and atheists of every class, 


\section{EVOLUTION AND SOCIAL PROGRESS}

using "Darwinism" as synonymous with materialistic evolution. Typical of the changed attitude towards real Darwinism, at this time, was the change that took place in the mind of Huxley himself: "The farther he went," wrote T. B. Crozier, "the farther he departed from his early belief in natural selection as the principal factor in the evolution of species." 3

Darwin held that in the so-called struggle for existence some species could more readily maintain themselves than others. Their favorable characteristics were then accentuated through constant transmission in successive generations. The less capable varieties succumbed.

Under a momentary spell of enthusiasm this theory was extended to almost every department of science and became a commonplace of literature. Materialistically interpreted, it postulated no plan governing this natural selection. And yet the necessity of such plan, even in his own hypothesis, constantly reasserted itself in Darwin's mind. The theory of sexual selection was added merely as a particular phase of his general doctrine.

All that need here to be said of the principle enunciated by Darwin is that it was wholly inadequate for the purpose of explaining either the "origin of species" or the "descent of man." At the best it might account for the elimination of

${ }^{3}$ Fortnightly Review, Jan., 19r4. 
the unfit. But it could cast no ray of light upon the only vital problem in question: the origin of specifically new qualities not possessed before. Thus no process of elimination can account for the formation of a new organ, much less, according to the theory of ultra-Darwinists, for the appearance of so wonderful an apparatus as the human eye or ear, or the marvelous and inexplicable power of reproduction, where it is presumed that these faculties had not existed before. Darwin himself denied that natural selection could be the cause of variations. It can therefore be at most a very secondary factor, accounting to a certain degree for the further accidental perfection of organs, already existing within a given species, but cannot possibly explain the origin of the species itself.

To Darwin's credit it must here be said that he refused to go the length of his militantly materialistic followers, and even freely confessed in his "Descent of Man" the need of accepting a preordination according to a previous design. Logically this could mean nothing less than the acceptance of a Creator, as Lyell pointed out to him on March II, I863: "I think the old 'Creation' is almost as much required as ever." Although in a familiar passage we find Darwin, by a strange confusion of mind, rejecting the "argument from design," 4 yet in the book

- Vol. I, page 309. 
just referred to he clearly recognizes his error, when he thus seeks to defend himself against the charge that his doctrine is irreligious:

I am aware that the conclusions arrived at in this work will be denounced by some as highly irreligious; but he who denounces them is bound to show why it is more irreligious to explain the origin of man as a distinct species by the descent from some lower form, through the laws of variation and natural selection, than to explain the birth of the individual through the laws of ordinary reproduction. The birth both of the species and of the individual are equally parts of that grand sequence of events, which our minds refuse to accept as the result of blind chance. The understanding revolts at such a conclusion, whether or not we are able to believe that every slight variation of structure, the union of each pair in marriage, the dissemination of each seed, and other such events have all been ordained for some special purpose.

What we are to think of the origin of man, both from a Scriptural and scientific point of view - the two being in perfect accord-we shall fully make clear. For the rest, Darwin, with his complete lack of knowledge in religious matters, which he quite frankly confesses, found a childish difficulty in accepting the idea of a Divine Providence carried into all the details of a supposed evolutionary process, though he does not here reject that possibility. A grasp of what is implied in the almightiness and omnipresence of God could readily have solved his difficulty, but he admits that he gave no thought to these

"Charles Darwin, "The Descent of Man," p. 6r3, Appleton, $\mathbf{8 9 6 .}$ 
questions so that his ignorance of such matters was often naïve, to say the least, as when he asked if his own nose was designed! To which Dr. Thomas Dwight replies :

A foolish speech by the way, and quite unworthy of him. As well ask whether the rings spreading over the water from a falling stone are designed. They are formed in accordance with certain physical laws. They vary with the size of the stone, and the height from which it descends. They vary also with the depth of the water, with its condition, whether it be at rest or flowing, and whether it be on a calm or windy day. In the same way the shape of a person's features depends first on the laws of generation, modified by those of heredity and probably by others of which we know next to nothing, such as the influence of surroundings. Moreover, many circumstances during childhood, such as health, climate, mode of life, must be counted. Design, it seems to me, is implied by the very fact of the establishment of those laws."

Yet Darwin obviously admits, in the passage quoted above, the need of what Lyell calls "the old 'Creation,'" though explained in a new way, and is forced also to accept, as the only alternative to an impossible blind chance, the truth of Lord Kelvin's words that: "science positively affirms creative and directive power," in as far as the denial of this would lead to what Darwin realized to be a preposterous assumption against which "the understanding revolts."

We do not, of course, accept his conclusions regarding the origin of man, but that is another chapter. Nor is there any desire here to explain

- "Thoughts of a Catholic Anatomist," pp. 98, 99. 
away the agnosticism of Darwin, which grew at the same time that he also lost his appreciation for art and beauty. So much we gather from his self-confessions. Yet to him, as to so many others who have never possessed the light of faith, the universe simply remained an insoluble mystery, if we are to trust his own words. He does not deny, but merely confesses his utter inability to decide upon a question to which he had never given the necessary consideration. Writing to Fordyce, in 1879 , he says of this subject:

What my own views may be is a question of no consequence to anyone but myself. But, as you ask, I may state that my judgment often fluctuates. In my own extreme fluctuations I have never been an atheist in the sense of denying the existence of God.?

Nothing, therefore, could be more untrue and more unhistorical than to confuse Darwinism with materialistic evolution whose first tenet is the utterly false statement that evolution has disproved the existence of a Creator. No such foolish arrogance ever asserted itself in the mind of Darwin. Quite correctly he says, when this question of religion is absurdly forced upon him for judgment, as if his position as a scientist could possibly render him an authority in such matters: "I feel in some degree unwilling to express myself publicly on religious subjects as I do not

"Charles Darwin, "Life and Letters," I, p. 274, same ed. 
feel that I have thought deeply enough to justify such publicity." 8

His attention, like that of many another scientist, had been restricted to purely material facts. However accurate these studies may have been, his deductions from them, even in the purely natural order, were not necessarily reliable, and at times were decidedly unwarranted upon the evidence he had gathered. But his labors could not furnish him with the slightest reason for dogmatizing upon religious matters. Would that all scientists, under similar conditions, had confined themselves to the confession made by him when he wrote: "I cannot pretend to throw the least light on such abstruse problems." 9 But again, it did not follow that because he himself failed to attain to an unshaken certainty regarding the existence of God, owing, we may presume, to his own want of effort and proper disposition, that therefore "the mystery of the beginning of all things is insoluble to us." It is insoluble merely to unaided science. Yet the intellect of Darwin, no more than that of any other normal human being, could be permanently blinded to the great truth of a Creator. Never in fact, even to its latest edition, did he eliminate from his bestknown work, "The Origin of Species," those concluding words:

${ }^{8}$ Ibid., p. 275.
'Ibid., p. 282. 
There is grandeur in this view of life, with its several powers having been originally breathed by the Creator into a few forms or into one; and that, while this planet has gone cycling on according to fixed law of gravity, from so simple a beginning endless forms most beautiful and most wonderful have been and are being evolved. ${ }^{10}$

Men like Wallace, Huxley, Asa Gray and Spencer greatly helped to popularize the Darwinian theory in the English-speaking world. Haeckel, as we have seen, carried it to such extremes that already in $\mathrm{I} 868$ Darwin wrote to him: "Your boldness makes me sometimes tremble." And good reason Darwin had for his apprehensions. The atheistic theory of the universe, according to which the entire order, beauty and glory of the existing world has arisen out of primal chaos through the accidental survival of the fittest, should be called Haeckelianism and not Darwinism. It was never Darwin's purpose to use his speculations as an attack upon religion, though they might readily lend themselves to this purpose.

So too the theory with which the name of Darwin is now most commonly associated in the popular mind, which makes of man in body and soul merely a more highly developed brute, was not originated by Darwin. As Wasmann points out, it was first mentioned in Huxley's "Evidence as to Man's Place in Nature." The same doctrine ${ }^{10}$ Charles Darwin, "The Origin of Species," II, pp. 305, 306, same ed. 
was still further developed by Haeckel in his "Natürliche Schöpfungsgeschichte," and then only taken up by Darwin in his "The Descent of Man." The latter book, indeed, is rightly referred to as the weakest of Darwin's scientific works. Alfred Russel, the prime exponent of the Darwinian principle, did not accept Darwin's own assumption that man's intellectual and moral faculties were derived from the brute, but vaguely ascribes them to the "unseen universe of spirit."

The impossibility of an evolution of the soul of man, a spiritual and simple being, from the purely material brute, with no higher faculty than brute instinct, is evident. But Darwinism itself, rightly understood, renders impossible also the concept of evolution applied to the body of man, since this could never have survived that very process of natural selection postulated by Darwin. It must, in fact, have been eliminated from the very first. As early as I 869 the Duke of Argyll had already clearly demonstrated this. The very direction in which the frame of man diverges from that of the brute would have singled it out for extermination, had it not been informed from the beginning with a rational soul.

It diverges in the direction of greater physical helplessness and weakness. That is to say, it is a divergence which of all others it is most impossible to ascribe to mere "natural selection." The unclothed and unprotected condition of the human body, its comparative slowness of foot, the absence of teeth adapted to prehension or for defense, the same want 
for similar purposes in the hands and fingers, the bluntness of the sense of smell, such as to render it useless for the detection of prey which is concealed-all these are features which stand in strict and harmonious relation to the mental powers of man. But apart from these, they would place him at an immense disadvantage in the struggle for existence. This, therefore, is not the direction in which the blind forces of natural selection could ever work. ${ }^{\text {II }}$

The imaginary brute developing in the direction of man would by the very hypothesis have been immeasurably below the lowest of the human race and must therefore inevitably have succumbed in the struggle with the powerful and terrible beasts of prey among which its lot would have been cast.

Darwinism, as the solution of the origin of species, has passed. Natural selection, as De Vries cleverly says, "acts as a sieve." 12 It cannot pro. duce new species. It does not even single out the best variations. It simply permits the larger number of the unfit to drop out of existence. In this way it may help to keep a species at a certain standard and may even, under special circumstances, tend to improve it accidentally. "Though it may account for the survival of the fittest it cannot account for their arrival." The theory of evolution still continues under a thousand different forms, but in these natural selection occupies a very subordinate place.

"1 Duke of Argyll, "Primeval Man," p. 66.

${ }^{12}$ DeVries, "Darwinism and Modern Science," p. 70. 


\section{TWENTIETH CENTURY EVOLU. TIONISM}

WHE curtain had hardly descended on what we have described as the second act of

1 our drama when the stage was already being set for new actors. Darwinism was henceforth to play a very minor rôle. Yet the name was still retained as a word to conjure with. Either carelessly or through ignorance it came to be applied to evolution in general, and often, in particular, to materialistic evolution alone. In both instances there was not the slightest reason for such an application, yet the wide ignorance of any true science made possible this usage in our popular literature, in sociology and popular history, and even in the class room where a most unintelligent dogmatism ruled supreme.

The two famous scientists, Albert Wiegand, botanist, and Louis Agassiz, zoologist and paleontologist, had from the first opposed Darwinism, and with it almost every phase of evolution. But Mivart, a vigorous evolutionist, was evidently regarded by Darwin as his chief opponent. Dar- 
winism may be said to have finally passed away almost with Darwin himself. The new school of scientists who flourished at the opening of the twentieth century united in their rejection of it, in the sense that natural selection was quite rightly regarded by them as of very secondary importance. Their own theories of evolution were countless in variety, including opinions innumerable, both old and new. Lamarck once more exerted a greater influence than Darwin, and the abbot Mendel towered high above them both in the sway his theories exercised over the minds of scientific men. In 1907 , not quite fifty years after the first appearance of the "Origin of Species," Professor Vernon Kellogg, himself a materialistic evolutionist, recorded in his work the opening obsequies of Darwinism. In his summary of modern evolution he wrote:

There has been from the day of the close of the first great battle to the present moment a steady and culminating stream of scientific criticism of the Darwinian selection theories. In the last few years it has reached such proportions, such strength and extent, as to begin to make itself apparent outside of strictly biological and naturo-philosophical circles. Such old biologists and natural philosophers as von Baer, von Kölliker, Virchow, Nägeli, Wiegand and Hartmann, and such other writers in the nineties and in the present century as von Sachs, Eimer, Delage, Haacke, Kassowitz, Cope, Haberlandt, Henslow, Goette, Wolff, Driesch, Packard, Morgan, Jaeckel, Steinmann, Korschinsky and de Vries are examples which show the distinctly ponderable character of the anti-Darwinian ranks. Perhaps these names mean little to the general reader; let me translate them into the professors of zoology, of botany, of 
paleontology and of pathology in the universities of Berlin, Paris, Vienna, Strasburg, Tubingen, Amsterdam, Columbia University, etc. ${ }^{1}$

Even the once indisputable theory of a gradual evolution was now disregarded by many of the. foremost scientists, and the "saltatory theory" or "theory of mutations," was widely accepted in its stead. It was popularized in particular by the efforts of De Vries. ${ }^{2}$ Such changes as may have taken place were now explained, not any longer by a slow process of evolution, which before it had been heresy to deny, but by a variation said to have appeared suddenly. The new form was thus thought to have at once been fully differentiated from all previous forms, as a socalled "sport" or "monstrosity" may be unexpectedly born at any time. But the new form was then supposed to have remained permanent. Whatever truth this hypothesis may contain, it obviously is no more capable of any final proof than the theory of slow mutations which it replaces. Nature refuses to yield up her secret. We see the new species appearing with a startling suddenness, and how they came to be we do not know. The rest is guess-work, more or less shrewd, with a measure of probability in a very restricted sphere.

The hypothesis that new species suddenly

${ }^{1}$ Darwinism To-day," p. 26.

"Die Mutationstheorie" (1901-1903). 
leaped into being, the "saltation theory," goes back in its origin as far as the epoch-making discoveries of Abbot Gregor Mendel, and was proposed at an early period by $\mathrm{R}$. von Kölliker and St. George Mivart, ${ }^{3}$ its protagonists. Later it was taken up and generally popularized by such eminent scientists as Hugo de Vries, Bateson, Korschinsky, Galton, Scott, Eimer, Emery and a host of others.

But the question may naturally be asked: If we must admit the sudden appearance of species, may we not as well assume instead their immediate production by direct creation, if so we desire, as by "discontinuous variation?" The new theory, it may be said, lessens the difficulties that might once have been urged against the direct creation theory of species. The fact is that neither theology nor science forces us to accept either one or the other conclusion. Theologically we are at perfect liberty, for as Father Knabenbauer, S.J., says: "There is no objection, so far as faith is concerned, to assuming the descent of all plant and animal species from a few types." 4 Scientifically we are equally free, for no theory hitherto proposed can even remotely be considered compelling in its evidence. "Evidence," indeed, is a large word to be used in connection with evolutionary theorizing. What

" "On the Genesis of Species." (187r.)

" "Catholic Enclycopedia," article, "Evolution." 
is needed above all things is less positiveness and more humility, such as the great Newton possessed. We have but scratched the surface of nature's secrets, and our sum of knowledge is little more than ignorance in the presence of the mysferies that surround us.

Not merely humility, but a sense of humor is wanting in materialism. Aside from the absurdity of that travesty before high heaven, which dictatorially pronounces upon the non-existence of a Creator as if evidence to this effect could be gathered from nature, we need but refer to the countless fantastic theories that have constantly sprung up into being. Under an incubus of learning that astounds the world are hatched out scientific follies which, if expressed in plain language and scrutinized in the cold light of reason, would make merriment for the nations. Though elaborately discussed in profound works of modern science until replaced by still newer theories and in turn profoundly forgotten, they deserve to be taken less seriously than the famous Miltonic description of Creation, which may at all events be considered a dignified conception of Almighty Power calling forth life from the dust of the earth, both interesting and poetical:

The grassy clods now calved, now half appeared The tawny lion, pawing to get free His hinder parts, then springs as broke from bonds, And rampant shakes his brindled mane; the ounce, 
The libbard, and the tiger, as the mole Rising, the crumbled earth above them threw In hillocks: the swift stag from underground Bore up his branching head: scarce from his mould Behemoth, biggest born of earth, upheaved His vastness. ${ }^{5}$

What little reason, in fine, there is for the loud assertions of professorial omniscience may be judged by the words of Vernon Kellogg when, alluding to the conflicting theories of those opposing giants of evolutionary science, Darwin and Korschinsky, he says:

After all, the Darwinian interpretation is proved only in so far as it possesses a high degree of plausibility and makes a convincing appeal to our reason. Of exact proof in the nature of observed fact or result of experiment, or of mathematical demonstration, there is little in the case either of the Darwinian or the Korschinskian interpretation.

Of exact proof, in brief, there is little to be boasted in the entire range of evolutionary theory, as this leading evolutionist admits after painstakingly studying its entire history. Yet Kellogg will not be held under suspicion of religious prejudices, for he loses poise just as soon as he forgets his scientific principles. $\mathrm{He}$ is a materialist of materialists, a causo-mechanist, who rules out of court all evidence that conflicts with his own favorite preconception. He has therefore the mind which the modern atheistic world considers imperative for the passing of an "un" "Paradise Lost."

Op. cit. 
biassed" judgment. His testimony is gladly quoted here as "above suspicion."

We began with blaming the materialistic evolutionist for an abyssmal lack of humor, particularly when from his theory of materialistic evolution he would draw, with unquestionable assurance, the far-fetched conclusion of the non-existence of a Creator God. The nature of the certainty possessed in the entire field of evolutionary lore was perhaps never better set forth than by a writer in the London Times, who thus pictured the situation towards the opening of the twentieth century:

No one possessed of a sense of humor can contemplate without amusement the battle of evolution, encrimsoned (dialectically speaking) with the gore of innumerable combatants, encumbered with corpses of the (dialectically) slain and resounding with the cries of the living, as they hustle together in the fray. Here are zoologists, embryologists, botanists, morphologists, biometricians, anthropologists, sociologists, persons with banners and persons without; Darwinians and neo-Darwinians, (what a name!), Lamarckians and neo-Lamarckians, Galtonians, Haeckelians, Weismannians, de Vriesians, Mendelians, Hertwigians, and many more whom it would be tedious to enumerate. Never was seen such a mêlée! The humor of it is that they all claim to represent "Science," the serene, the majestic, the absolutely sure, the undivided and immutable, the one and only vice-gerent of Truth, her other self. Not their's the weakness of the theologians or the metaphysicians, "who stumble about in uncertainty, obscurity, and ignorance, with their baseless assumptions, flimsy hypotheses, logical fallacies, interminable dissensions, and all the other marks of inferiority on which the voteries of science pour ceaseless scorn. Yet it would puzzle them to point to a theological battlefield exhibiting more uncertainty, obscurity, dissension, assumption 
and fallacy than their own. For the plain truth is that, though some agree in this and that, there is not a single point in which all agree; battling for evolution, they have torn it to pieces; nothing is left, nothing at all on their showing, save a few fragments strewn about the arena."

To the objection that this must surely be an exaggeration, Sir Bertram Windle answers that it is nothing more than a literary expression of what in a formal scientific way must be gathered from Kellogg's own summaries of our evolution theories. And Kellogg cannot be accused, as he adds, of anti-Darwinian bias, nor does he conceal his contempt "for the poor deluded Catholic." Such, therefore, is the haze and mist of uncertainty that like a dense cloud cover almost the entire subject of evolution.

Why then this dishonesty in classroom and textbook? Why this presentation of materialistic evolution as an established and unquestioned fact, when it was never even a credible theory, in the sense that it was never based upon sufficient evidence to make of it a scientific possibility? Why the open regret expressed by certain noted scientists, that after all evolution has not disproved the existence of God-as most certainly it has not succeeded in doing? Is materialistic evolution merely a symptom of the disease, common enough in scientific circles, which has quite cor-

"Times, June 9, 1905. Quoted by Sir Bertram Windle in "Facts and Theories," pp. 94-95. 
rectly been diagnosed as theophobia: a fear of God that is neither a gift of the Holy Ghost nor yet the beginning of wisdom? It would certainly seem so.

Evolution, in brief, is acknowledged to have been a failure because it has not accomplished the one thing it was intended to accomplish, not indeed by Darwin, but by his lesser followers, and by men who, like Haeckel, sought to convert "Darwinism" into an engine for the destruction of Christian religion. Bateson, in a reference to Mendelism, finds that: "It is not so certain as we might like to think that the order of these events is not predetermined"-a clear case of theophobia, while Weismann desperately clings to Darwin's now hopeless theory of natural selection, just because: "It is inconceivable that there should be another capable of explaining the adaptation of organisms without assuming the help of a principle of design"-purely theophobia again. ${ }^{8}$ They will cling to any drifting straw, provided only that they may forsooth escape the acknowledgment of a Creator.

It was therefore impossible for the men ultimately responsible for the deception of the masses through their widely preached dogma of materialistic evolution, and so ultimately responsible also for the tremendous social cataclysms and the

8 "Darwin and Modern Science." See Windle, "Facts and Theories," pp. 24-27. 


\section{4}

EVOLUTION AND SOCIAL PROGRESS

wreck and ruin of civilization, not to have been aware that they were proposing as a certainty what has never been established and never can be proved; that in no important step of their entire process could they ever claim more than a probability at the most, and that even this was often entirely wanting; that finally in many instances they were drawing conclusions in defiance of all right reasoning. Hence the dreadful consequences that were inevitably to follow and are yet to come.

While on the one hand we find Huxley absurdly proclaiming to the world that one of the greatest merits of evolution was that it "occupies a position of complete and irreconcilable antagonism" to the "Catholic Church, ${ }^{9}$ on the other we have the striking irony of fact that this Church, supposed to be irreconcilably opposed to evolution, has given to science five out of the eleven founders of the various branches of biology, the one science which stood in closest relation to the doctrine which was fabled to be anathema to her. It will be interesting, therefore, to explain still somewhat more definitely where Catholic evolutionists stand on this question.

'"Darwiniana," p. ${ }_{477}$ 


\section{CATHOLICS AND EVOLUTION}

T $\mathrm{TE}$ declare that every wise thought and every useful discovery, wherever it may come from, should be gladly and gratefully welcomed." 1 These words of Pope Leo XIII will sufficiently define the attitude of Catholics towards evolution. The Church is eager as any scientist can ever possibly be for the truth, but, as was already stated, she desires the whole truth and nothing but the truth.

There is no fact that science can demonstrate, "wherever it may come from," in the words of the Pontiff, or whatever it may be, that will not be "gladly and gratefully welcomed" by her and accounted as gain. Let it be clearly understood that there is no limit and no exception to this statement. No true child of hers is the Catholic scientist who harbors in his heart even the faintest suspicion that any discovery of science could ever contradict the Word of God. Least of all, however, is the Church ever to be startled by the word, "Evolution." Hear what the blind Jesuit

${ }^{1}$ Encyclical "Aeterni Patris," Aug. 4, 1879. 


\section{orator, Father Robert Kane, has eloquently to say upon this subject:}

Evolution? It is an old story told by old men, long ago.

Fourteen centuries ago, all the principles of evolution that are not irrational were taught by the great St. Augustine. He held that all things at first existed only as Semina rerum (the seeds of what was to be), that there was at first in things only the potency of what, under the action and reaction of strong or slow forces, they should become; that during days which were epochs of unmeasured duration and of cumulative result, the Moulder of the world worked merely through natural elements and uniform laws, until the universe crystallized into order. He held indeed, as all who are not materialists must hold, that man's spiritual soul was not made of mere mud nor begotten of a monkey, but was created by the immediate power of God. Since Augustine, this theory has been commonly accepted as a probable hypothesis by Christian theologians.

There is as much wonder in an acorn as in an oak. In that bewildering world of interlocked atoms or rebounding vortices, of subtle gas or seething vapor, of dizzy whirl or aeonic change, of molten mass or adamantine ice, of eddying unison or of titanic clash, there was the potency, the germ of all that is or shall be.

Now we look upon the branching forth of that strange power which then was in the seed. But to go no further than an acorn for ultimate explanation of an oak, is to stop short upon the threshold of thought. To account for the oak, the acorn, and the universe, by the virtue of some primitive cell which held within it the potency of all worth and the energy of all power, which, yet, had no cause, no reason other than itself, is to change science into superstition, and to learn history from the "Arabian Nights."

Is that facing the issue squarely? And of the great patristic writer of the Church above re2 "God or Chaos," pp. 170, 17 I. 
ferred to, Father Wasmann says: "Even to St. Augustine it seemed a more exalted conception, and one more in keeping with the omnipotence and wisdom of an infinite Creator, to believe that God created matter by one act of creation, and then allowed the whole universe to develop automatically by means of the laws which He imposed upon the nature of matter.

"God does not interfere directly with the natural order when He can work by natural causes: this is a fundamental principle in the Christian account of nature, and was enunciated by the great theologian, Suarez, ${ }^{3}$ whilst St. Thomas Aquinas plainly suggested it long before, when he regarded it as a testimony of the greatness of God's power, that His providence accomplishes its aims in nature not directly but by means of created causes." 4

To show that this idea was by no means strange to St. Augustine, St. Thomas, St. Bonaventure and others, reference is made by the author to Father Knabenbauer's specific treatment of the relation of Faith to evolution. ${ }^{5}$

It is therefore an old theory within the Church that the act of Creation took place at once, and that what followed was but an evolution accord-

"De Opere Sex Dierum," r. 2, c. ıо, n. 12.

" "Modern Biology," p. 274.

"Glaube und Deszendenztheorie." Contributed to the Stimmen aus Maria-Laach, XIII, r877, pp. 75 ff. Cf. T. Pesch, "Philosophia naturalis," II, pp. 24I ff, and "Die grossen Welträzel, II, pp. 349 . 
ing to the laws that God had given. Since a separate Creation, we have said, is philosophically required for the origin of life, it is supposed in this theory that the seed or seeds of life were virtually present in semine "in germ" and all living things were later evolved, under God's Providence, from the seeds thus created originally. The days of Creation are then explained as merely "marks of progression or indefinite periods." Father Hull thus interprets St. Augustine's hypothesis:

He says that while the original act of Creation was direct and simultaneous, the subsequent formation was gradual and progressive. He tells us distinctly that animals and plants were produced, not as they appear now, but virtually and in germ, and that the Creator gave to the earth the power of evolving from itself, by the operation of natural laws, the various forms of animal or vegetable life. His treatment of the subject, in fact, reads like the anticipation of a modern scientific treatise. His view did not "necessitate perpetual search for manifestations of miraculous powers and perpetual catastrophies" but a search "for the institution of laws of nature rather than interference with them."

St. Thomas Aquinas, in the thirteenth century, commenting on St. Augustine, declares that "in the institution of nature we do not look for miracles but for the laws of nature." $\mathrm{He}$ gives preference to the view of St. Augustine as against that of St. Basil, saying that "while the latter is more conformable to the text, the former is more reasonable, and better adapted to defend the Sacred Scriptures against attacks of unbelievers." • As regards the apparent division of the creation-process into several parts, and the picture of God issuing successive edicts to bring successive events about, St. Augustine has some very wise words on the folly of trying to take all the statements of

"From Zahm, "Bible Science and Faith," p. 84 
Genesis literally," and says: "Although the creation is presented to us as though it took place in regular (i.e., separate) sequence, yet it really took place at once." ${ }^{8}$ On this St. Thomas remarks: "And so Moses, since he was instructing an uneducated people about the work of Creation, divided up into parts what really took place at once." 9

Father Bernard J. Otten, in his learned work on the history of dogmas, writes of what these authors describe as the Augustine theory of evolution that: "Although the rationes seminales were implanted in matter at the beginning of time, nevertheless the actual production of finally complete beings is according to him [St. Augustine] the work of God, and not of matter alone." 10 It is thus at all events distinct from all forms of materialistic evolution. In illustration the following quotation is offered from the writings of the Saint:

The earth is then said to produce the herb and the tree causally-i.e., it received the power to produce them. For in it were now made, as in the roots of time, those things which were afterwards to be produced in the course of time. God afterwards planted Paradise, and brought forth of this earth all manner of trees fair to behold and pleasant to eat of. But we must not suppose that $\mathrm{He}$ added any new species (creatura) which $\mathrm{He}$ had not previously made, and which was needed to complete the perfection of which it is said that they were good. No, for all the species of plants and trees had been produced in the first creation (conditione), from which God rested, thenceforth moving and administering, as time went on, those same things.

${ }^{7}$ De Gen. Contra Manich., xx, 2.

${ }^{8}$ De Gen. ad Lit., VI, II, 12.

'Examiner, March 6, 1920, p. 93.

${ }^{10}$ "A Manual of the History of Dogmas," I, pp. 29 r, 292. 
which $\mathrm{He}$ had formed. Not only did He then plant Paradise, but even now all things that are produced. For who else creates them now, but $\mathrm{He}$ who worketh until now? For $\mathrm{He}$ creates them now from things that already exist; then, when they had no existence whatever, and when that day (the first) was made. ${ }^{11}$

It is very interesting to note in this connection how the Batesonian theory, described as Mendelism to the $n$th power, recalls the Augustinian view, surprised as its author may be to hear this mentioned. Every new evolution, according to him, was contained in the original organism. Variations are merely the result of removing something that prevented certain hidden characteristics from freely manifesting themselves. A reviewer of Professor Adami's "The Lecture on Life," a medical contribution to the study of evolution, thus writes of Bateson's thesis in the Dublin Review:

The theory logically necessitates the incredible view that the original microscopic sphere of protoplasm, which evolutionists postulate as the beginning of life, must have contained all the properties of all living things and therefore, must have been the most remarkably endowed organism ever existing. He says that "the potentiality was there, not the determinants." The last word being used, of course, in the Weismannian sense. We agree with him but would like to remind him that the sentence is almost a literal translation of St. Augustine's "nihilominus potentialiter, quorum numeros tempus postea visibiliter explicaret." A short reflection may prevent the author from further jibes at medieval schoolmen.

${ }^{11}$ De Gen. ad Lit., V, 4 Italics by the present writer. 
It will suffice finally to quote upon our subject the statement of a foremost Catholic lay exponent in the scientific field whose labors have been of notable service to both science and Faith, and who in his own person shows the perfect harmony that exists between them. "To me, at least, it seems," Sir Bertram Windle says, "as if the language of Peter Lombard and of St. Thomas Aquinas in commenting on St. Augustine, makes it clear that the teaching of the greatest and most influential Doctor in the history of the Church is quite consonant with any reasonable theory of evolution-nay, it is broad and comprehensive enough to provide not only for whatever limited degree of evolution is yet fairly established, but even for anything that has even a remote probability of being proven in the future. Nor am I deterred from coming to that conclusion by the very obvious criticism that the Saint did not state the doctrine with the clearness with which it is now laid down, a thing which no reasonable being would expect him to have done." 12

More need not be said. Catholic evolutionists, in brief, hold as probable the theory that the organic world has assumed its present form, "not in consequence of God's constant interference with the natural order, but as a result of the action of those laws which He Himself has im-

1s "A Century of Scientific Thought," p. 8. 
planted upon nature." In the question of the origin of species, there would thus be as many or as few natural species as there were primitive forms created, and the creation of these first organisms, so far as we may assume it, would not necessarily be out of nothing, but out of pre-existent matter, until we would finally come back to original creation in the strict sense of the word, such as reason postulates. Matter cannot be self-existent, philosophy teaches, nor can life be educed from dead matter. Here therefore at least two strictly understood creative acts are required by reason itself, as also in the creation of the rational soul of man.

The natural (i.e., distinctly created) species would then be differentiated, by the process of evolution, into more or less systematic species, whose extent it is left to natural science to determine. "Eventually many hundreds of thousands of systematic species may unite to form one single line, one natural species." All this is understood to be pure, but perfectly legitimate, hypothesis, and by species are not understood species metaphysica, of logic; but species physica, of natural philosophy. Whatever therefore may be each one's private opinion-since it would be rash to speak of certainty on either side-every believing Jew or Christian can heartily subscribe to Wasmann's conclusion that whatever the fate 
of evolution may be, the Christian cosmogony remains as firmly established as ever. ${ }^{13}$

Surely there is no need of trembling for the Rock on which Christ built His Church. True science will ever prove the strongest natural defense of religion. It is the breakwater on which every wave of false theory must eventually be dashed to foam and idle spray.

Before beginning, with the following chapter, our special consideration of the book of Genesis, it may be well to quote here in conclusion the words of that eminent Scripture scholar, Father Knabenbauer, S.J., as given in the "Catholic Encyclopedia." "In what particular manner the plant and animal kingdom received their existence," he writes, "whether all species were created simultaneously, or a few only, which were destined to give life to others; whether only one fruitful seed was placed in mother earth, which under the influence of natural causes developed into the first plants, and another infused into the waters gave birth to the first animals-all this the book of Genesis leaves to our own investigation and to the revelations of science, if indeed science is able to give a final and unquestionable decision. In other words, the article of Faith contained in Genesis remains firm and intact, even if one explains the manner in which the different ${ }^{23}$ See Wasmann, "Modern Biology," pp. 296-302. 
species originated according to the theory of evolution." 14

It has been the purpose of this chapter to cite a variety of Catholic authorities that no doubt may be left as to the true nature of the liberty granted upon this subject within the Church. No better summary can therefore be given of the entire question than that offered by Father F. P. Siegfried in the article just referred to.

"The two general biological problems connected with the Biblical cosmogony," he says, "are the origin of life and the succession of organisms. Concerning both these problems all that the Catholic Faith teaches is that the beginnings of plant and animal life are due in some way to the productive power of God. Whether with St. Augustine and St. Thomas, one hold that only the primordial elements, endowed with dispositions and powers (rationes seminales) for development, were created in the strict sense of the term, and the rest of nature-plant and animal life-was gradually evolved according to a fixed order of natural operation under the supreme guidance of the Divine Administration $;^{15}$ or whether, with other Fathers and Doctors of the School, one hold that life and the classes of living beings-orders, families, genera, species-were each and all, or only some few, strictly and imme-

${ }^{14}$ Article, "Creation"; section "Creation and Evolution."
${ }^{25}$ Harper "Metaphysics of the School," II, p. 746. 
diately created by God: whichever of these extreme views he may deem more rational and better motived, the Catholic thinker is left perfectly free by his faith to select." 16

${ }^{10}$ Loco. Cit. 


\section{EVOLUTION AND GENESIS}

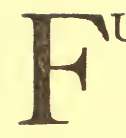

VULLY to satisfy the inquiring mind on the subject of evolution a word must be said on the "Six Days" of Creation as narrated in the Scriptures. This is important because of the materialistic literature that would here in particular leave the impression that science and the Bible are irreconcilable, and that therefore man need look for his origin to nothing further than eternal, uncreated matter. On this assumption rationalism and Socialism, anarchism and profiteering are alike founded in their philosophy. A correct understanding of the "Six Days" of Creation comes therefore to have a most practical relation to our every-day life and to the welfare and prosperity of mankind. Such, too, we can without hesitation say, was the purpose of the inspired account, on which the greatest of all labor legislations is based, that has done more to humanize industrial life than any economic ordinance: the Sunday law.

The astounding parallel which can be established between the Mosaic narrative and the most 
advanced discoveries of our various natural sciences is in fact such that it evoked from Ampère the emphatic remark, that will not seem startling to any one acquainted with this interesting theme, that: "Either Moses knew as much about science as we, or else he was inspired."

And yet there is no need whatsoever of leaning upon science for an intelligent and wholly satisfactory explanation of the Sacred Text. Thus, among various interpretations that can quite reasonably be given, it will suffice to call attention to the interesting "vision theory," which prescinds entirely from all scientific explanation. It regards the successive days as merely successive visions, in which the work of creation was unrolled before the sacred seer, without any necessary regard to a strictly chronological order. Not unlike the cinema, each vision might thus have faded away into darkness and the new revelation have again dawned in light. Such visions could have been shown in dream. The sequence of events might then have been chosen just to serve the end intended. Any logical order would have sufficed, as in a historical work, military, political, social and cultural events can be grouped separately, no matter what their chronological order may have been.

It need not be supposed that these revelations were made at the time that the book of Genesis was composed. They may have been given to the 
first progenitor of the human race, and handed down by tradition through successive generations. This would account for the distorted narratives of the Creation, mingled with debasing superstitions of every kind, that were transmitted along different lines. Thus contrasting the Biblical and Babylonian versions, Professor Sayce writes:

The resemblances and differences between the Biblical and the Babylonian accounts are alike striking. The polytheism which underlies the one [Babylonian account] with the thinly veiled materialism which overlies it, is not more profoundly contrasted with the devout monotheism of the other [the Biblical account], than is the absolute want of the mythological details in Genesis with the cosmological myths embodied in the cuneiform poem. We pass, as it were, from the "Iliad" to solid history. Where the Assyrian or Babylonian poet saw the action of deified forces of nature, the Hebrew writer sees only the will of the One Supreme God. ${ }^{1}$

While, therefore, the various versions of the Chaldean tablets and the Egyptian writings preserved for us are apparently perverted traditions of a primal Revelation, changed by a gross and carnal imagination into the idolatrous myths of Assyrians, Babylonians and Egyptians, the true account could readily enough have been providentially preserved by a portion of the race, that retained the true faith, and so would at length have been handed down to Moses, and through him to the later generations. Thus the explanation of Hugh Pope on this subject seems to be 1 "The Higher Criticism and the Monuments." 
entirely satisfactory and reasonable, as well as perfectly consonant with God's Providence when he says:

It is a striking fact that the Bible presents to us Thare and Abraham as believers in the one true God; and it would seem as though from the days of Noe, God had preserved for Himself a portion of the human race untainted by the prevailing idolatry. He had revealed Himself to Adam and again to Noe; yet it is implied all through this early period of the history, that, in spite of the defection of the vast majority of mankind, there was always a chosen seed which did not stand in need of a new revelation of what had once been declared, though it did at times call for drastic purification from the errors which had inevitably crept in through contact with the unbelievers in whose midst they lived. It would seem, then, more in accodance with the facts to suppose that all along the course of the history the true account of God's dealings with man and of His formation of the world and of the human race had been preserved undiluted and was handed down from century to century. Indeed, when we come to reflect upon it, a purification of the Chaldean account of the Creation or of the Flood would have involved an almost radical change of the accounts. ${ }^{2}$

While we are not, therefore, obliged to establish a chronological parallel between the Scripture account and that of science, yet, when actually made, such a parallel discloses the most wonderful harmony of all the facts and even of the most highly probable theories of geology, astronomy, optics, biology, paleotology, etc., with the simple narrative of Holy Writ.

It is sufficiently understood by all, at the pres2 "The Catholic Student's 'Aids' to the Bible," pp. 197, 198. 
ent date, that the Mosaic word for "day" can be taken to signify any period of time, no matter how many millions of years we may wish to postulate. Such is clearly the Scripture use of the word in question. The eons, therefore, of the various nebular hypotheses do not in the least perplex the Scripture scholar. But we may state at once that there is no reason for postulating millions of years for the age of man. This however is a subject which shall be treated in its proper place. ${ }^{3}$

That the idea of evolution, applied to the work of the Six Days, can offer no difficulty to the Catholic student has been made evident in the preceding chapter. We can therefore proceed directly with our explanation of the most approved scientific theories, and compare them carefully with the Scripture record, assuming for the time a strictly chronological order. Yet, this, we repeat, the Scripture scholar is not obliged to do in order to safeguard the accuracy of the sacred writings.

In the beginning, science pictures immense drifts of atoms or ions wandering in the vast of ethereal space, uniting ultimately into luminous systems, hazy, nebulous, cloud-like masses, out of which in course of time evolved the stellar worlds. The original nebula, as the very latest theories hold, may have been loose swarms of cold me-

${ }^{3}$ See Chapter XVII. 
teorites that developed heat merely by the process of self-condensation. But whence these original atoms came, how these meteor swarms arose that first traced their unknown path through those measureless solitudes of space, science is not commissioned to teach. Yet reason confirms what Faith tells us in the opening of that great account of the origin of all things that were made:

In the beginning God created heaven and earth.

The origin of both matter and life, as has been shown, necessarily postulates a Creator, who of His very nature must be self-existent. Evolution postulates Him no less, in the wonderful laws that could have proceeded only from a Supreme Intelligence and could have been applied only by a being of transcendent power. Such is the First Cause, God, simple and infinitely perfect, without whom the world is inconceivable. Right reason cannot but confirm this first lesson of Holy Scripture: that the heavens and the earth are not the work of blind chance, against which our intellect revolts, but owe their existence to God. Yet nothing is here stated for or against evolution.

The nebular hypotheses are naturally the first to which we turn, to see how closely their evolutionary deductions conform with the Sacred Books. Yet nebular hypotheses, too, have followed each other in rapid succession. Joseph 


\section{2 EVOLUTION AND SOCIAL PROGRESS}

Barrell, professor of structural geology in Yale College, thus traces their history:

During the first half of the nineteenth century the nebular hypothesis was accepted by astronomers almost without question, but during the second half many serious dynamical objections were developed and a process of modifications began [a series of new hypotheses] until not much remains of the original conception of Laplace. . . . A hypothesis to gain scientific credence must emerge successfully from the test of observed facts and mathematical theory. The nebular hypothesis has not done so. It is on the defensive and has lost standing during the past generation."

These reflections bring home with new force the wise warning given to Catholics by the eminent Cardinal Newman:

It has seemed to me very undignified for a Catholic to commit himself to the work of chasing what might turn out to be phantoms, and, in behalf of some special objections, to be ingenious in devising a theory, which, before it was completed might have to give place to some theory newer still, from the fact that those former objections had already come to naught under the uprising of others. ${ }^{8}$

To the above admirable passage Sir Bertram Windle adjoins the reply of Clerk Maxwell, the originator of the electro-magnetic theory of light. When consulted by Bishop Ellicott, in I 876, regarding the mention of light in Genesis previous to the first mention of the sun, Maxwell prudently counseled the Bishop against pinning any text of Scripture to a conjectural hypothesis, even " "The Evolution of the Earth." Chapter I, "The Origin of the Earth," by Joseph Barrell, pp. II, I2.

"Apologia." 
though this chanced to be his own. His warning is the very same that Cardinal Newman had given. It is no exaggeration when he says: "The rate of change of scientific hypotheses is naturally much more rapid than that of Biblical interpretations, so that if an interpretation is founded on such an hypothesis, it may help to keep the hypothesis above ground long after it ought to be buried and forgotten." 6

So much for scientific hypotheses, that in the schools themselves are too often confounded with scientific facts. Yet with these precautions in mind, it is nonetheless well to show how "the Mosaic account tallies with the chronological development of the earth, as we now conceive of it." 7 This we shall here attempt to do with reference to the most scientific thought upon the subject.

Yet to correct current preconceptions, based upon entirely false assumptions, a few suggestive remarks may still profitably be made before we approach this interesting task. We read much in sociological and in general literature of the Scripture "myth" of Creation. It is presumed that the accounts given in the first chapter of Genesis cannot be taken seriously by scientific men. The fact that they have been so taken by many

" "Life of Clerk Maxwell," p. 394.

"See Sir Bertram Windle, "The Church and Science," pp. r71I92. 


\section{4 EVOLUTION AND SOCIAL PROGRESS}

of the most eminent scientists, as has been shown in the preceding chapters, might suffice to answer this statement. Yet the difficulties can best be met by an intelligent explanation making plain that it is not necessary or even possible always to assume a literal interpretation for the various Scripture texts.

Thus in connection with the early chapters of the Book of Genesis it is well to bear in mind, in the first place, the principle laid down by one of the foremost of Scripture scholars, St. Jerome, that occasionally certain things in the sacred writings may be said "according to the ideas of the time, or according to the appearance of things rather than according to the actual truth." We thus express ourselves today when we speak of the rising and the setting sun. It was quite consonant with God's ways to permit the sacred writer to clothe the truth in the language of his own time. In this there can be no question of error.

In the second place Patristic commentators have always given ample attention to allegorical or symbolical interpretations of the inspired text, where there was sufficient reason for such conclusions. Certain facts must of course be taken in a strictly literal sense, but others admit of a symbolical sense or demand it. Various illustrations might be given. The most obvious is that often referred to in our social literature as 
"anthropomorphism," where God is represented as speaking, acting, resting, like a human being. Nothing was clearer to the inspired writer than the fact that God is a pure spirit, yet the oriental imagination naturally pictured the Deity, Jahweh, the eternal, self-existent God, under human form. So, too, He was represented as appearing to our first parents and freely conversing with them. On this point Father Hull says:

Some would take the narrative as literally as possible, and suppose that God took an apparitional form as a sort of sublimated man; and in that form $\mathrm{He}$ walked and talked and argued. The more modern tendency would be to dispense with such apparitional forms, and reduce the occurences to the mental order; for instance, that God's commands mean merely His efficacious will issuing in effect; that His speaking to Adam was merely a mental impress in man's inner consciousness, etc. The apparitional view is possible, but the mental view is perfectly orthodox, so long as it is maintained that something did historically occur corresponding to the symbol. It must be upheld that God did impress some command on Adam's conscience; that Adam really experienced the feeling of a bad conscience; that he realized he had done wrong and had brought punishment on himself, etc. In this way the historical and religious validity of the story is preserved; and this is at once necessary and sufficient for orthodoxy.

Yet there is never any need of straining the meaning of the Scripture account. Admitting an Almighty Creator, as we must do, it is childish to question His power, nor need we doubt His condescension with the creatures $\mathrm{He}$ has called into being. With these statements premised we

${ }^{8}$ Examiner, March 27, 1920, p. 126. 


\section{II6 EVOLUTION AND SOCIAL PROGRESS}

shall consider in the two following chapters the most accredited scientific hypotheses, without, at the same time, pledging ourselves for their accuracy. 


\section{HOW THE EARTH WAS MADE}

$\mathrm{F}$

AR back in the measureless abyss of time, our imagination first beholds the glowing nebular mass whence science would trace the origin of our solar system. Earth and its future moon were begotten in this fiery birth. Torn away at length from the spiral nebula of their parent sun, by the attraction of some great star that swung by in its orbit, or in whatever other way scientific hypotheses may still picture this event, they slowly radiated their heat into the surrounding space. Only when this had been done could the earth-mass densify and contract into a solid globe. Henceforth it ceased to be self-luminous. But it was void and empty, wrapped in mist and clouds.

In the intense heat through which the earth had passed in its formative period no germ of life could possibly have subsisted, as all scientists agree, unless indeed we are to speak of a seminal virtue placed there from the first by the Creator, in the sense assumed by St. Augustine. On its surface, science tells us, clouds rested miles 


\section{8 EVOLUTION AND SOCIAL PROGRESS}

in depth. Of any light that could penetrate this dense mass of gaseous and watery vapor there could be no slightest question. Most literally there was verified in every detail the sublime description of the inspired writer:

' And the earth was void and empty, and darkness was upon the face of the deep; and the spirit of God moved over the waters.

All the earth surface was then, in the strictest sense of the word, one waste of waters that covered the solid land, and over their mighty waves moved, with his vivifying and energizing power, the Spirit of God. Slowly the seething volumes of vapor were now condensing and falling in perpetual rains upon the earth, an unending Noachian deluge. The conditions are most graphically described by the Yale professor of structural geology already quoted, whose words read like a commentary on the Scripture passage just cited. Yet nothing doubtless was ever farther from his mind. Here, then, as he sees it, is the picture of the earth at this stage of its development:

Then rain, ever descending from the shield of perpetual cloud, but never heretofore reaching the bottom of the atmosphere, at last began to splash on the hot surface of the earth. The raindrops at first were dissipated by contact and sent flying as scattered molecules of gas. But, owing to the low conductivity of rocks, the transition stage was very brief, and perhaps even in a few thousand years from the time when the crustal congelation of the earth had taken place a permanent ocean of acid water began to rest upon the surface. For a 
while the balance swung, as one section or another of the crust was broken through and lavas would pour out abundantly. Rapidly, however, from the geological standpoint, as the surface cooled, the atmosphere of water-vapor condensed in a never ceasing deluge until an ocean, probably universal in its extent, had gathered to a mean depth of several thousand feet. ${ }^{1}$

Now, and now only could there be question of light on the face of the earth. The condensation of the great zone of vapor that had encompassed this watery world made possible at last the first admission of light. At this same point the Scripture too makes its first mention of it:

And God said: Be light made. And light was made.

Yet the Scripture account would seem even more minutely to bear out the teaching of science. Relative to the earth, this light could most certainly not be spoken of as "the sun." When light first appeared it was but the luminosity of a nebular mass, a vapor, a gas, a cloud; but in no sense a sun. Yet even when the sun had probably been formed, and its light was first introduced through the blanket of mists that covered the earth it could not have been described other than as a diffusion of faint radiance. It was "light," but not a sun that would have been visible here on the watery surface of the terrestrial globe. It has even been held that the sun itself was at this time still but a cloudy volume of nebulous or gaseous matter, diffusing a compara-

${ }^{1}$ Op. cit., pp. $37,38$. 
tively weak light through its own dense atmosphere. Naturally the earth, reckoned as originally $\mathrm{I}, 300,000$ times smaller, condensed much sooner than the vast nebula from which it had been detached. In any event we must appreciate the perfect scientific accuracy, from a purely scientific viewpoint, of the mention of "light" alone by the inspired writer, reserving the first reference to the "sun" for the period, when from the earth's surface it might at length have been visible, as the poet saw it: "Flattering the mountain tops with sovereign eye." But no less striking is the scientific accuracy of the Scripture passages that now follows:

And God saw the light that it was good; and he divided the light from the darkness. And he called the light Day, and the darkness Night; and there was evening and morning one day.

Thousands of years before our discovery of the rotundity of the earth, the Scripture writer had penned these lines. Today we find them in full conformity with all our present science. Although the light from the sun or solar nebula was still but faintly diffused through the mist, with its source certainly undefined as it might have been viewed from the newly formed earth, yet it had sufficed to establish Day upon the side of our planet turned towards this source of radiance, while Night had by contrast resulted upon the opposite hemisphere. Thus, for the first time 
was light separated from the darkness, precisely as the Scripture writer says: one hemisphere basking in the effulgence of the constantly brightening rays, while the other lay veiled in dense and stygean gloom.

And God said: Let there be a firmament made amidst the waters: and let it divide the waters from the waters.

Nothing, again, is more clear to modern scientists than this division of the waters that now took place when the vaporous zone about the earth was separated into two parts: the waters that settled upon the surface of the earth's crust and those that floated as clouds on high. The solid globe of our planet was spanned at length with what the sacred writer calls "the firmament," although the heavenly luminaries did not as yet shine forth in it. It was evidently meant to describe the atmosphere "amidst the waters." The air, we must remember, had not been from the beginning as we now know it. More recent geoglogists, like Chamberlain, hold that there was a time when the earth had no atmosphere at all. Only gradually, at all events, did it assume its present chemical conditions, and was cleared of its noxious constituents. Between the canopy of the clouds, through which the light was diffused with increasing brightness, and the ocean that hitherto had covered the earth, there henceforth existed what the translator has rendered by the English 


\section{22 EVOLUTION AND SOCIAL PROGRESS}

word, "the firmament." It was the atmospheric space between the two worlds of water. And now took place what geologists describe as the next development upon the earth crust:

God also said: Let the waters that are under the heavens, be gathered together into one place: and let dry land appear.

Here, therefore, is in a few words the perfect scientific account of the formation of the ocean basins, which occurred in the most marked degree, as we may believe, at this particular period. We have already quoted at some length the geological description of the universal ocean that had covered the earth at a previous period. The sinking of broad areas of the earth-crust, which now took place, caused the surface waters to pour in mighty water-falls into these great hollows, allowing the dry land to appear for the first time. Such sinkings of the earth's crust have of course taken place also at later times, though never to such an extent as then.

"This regional subsidence was especially characteristic of primordial times," says the writer just referred to, "but the process did not wholly cease then; since certain lines of evidence suggest that some ocean basins have been extended in later geological ages, breaking into once wider continental platforms." 2 Thus in every line and letter do our most scientific conclusions conform ${ }^{2}$ Op. cit. p. 39 . 
here with those of the Sacred writer as he limns, with the sureness of touch and the boldness of stroke of an unequalled master artist, the first making of our planet, with its hemispheres of light and darkness, its gathering oceans and its rising continents. 


\section{HOW LIFE APPEARED ON EARTH}

JNTINUING our application of science to the Scripture account we now meet with an apparent difficulty. Before the sun is mentioned in the Sacred Text the creation of plant-life is fully described for us. In explanation we shall return once more to the series of Yale lectures delivered with no purpose of reconciling Scripture with science, a reconciliation, be it here said, never objectively called for. The supposed "warfare" between Scripture and science can be based only upon a defective interpretation of the Sacred Books or else upon the too-common error constantly pointed out here, of mistaking mere scientific theories for established facts.

Lorande Loss Woodruff, professor of biology, alluding to Osborn's theories, definitely refers to the existence of life elements upon the earth "before the atmospheric vapors admitted a regular supply of sunlight." 1 There is consequently no reason for denying that lower forms of life may well have existed before the sun was clearly

1 "The Evolution of the Earth," p. 105. 
rounded and defined in the sky or could have been visible from this earth as now we see it. "The plants and trees composing the carboniferous strata," believes John Smyth, "may have flourished luxuriously on the margin of shallow seas long before the sun deserved the name of a great light." 2 However this may be, since science can but stammer and surmise, it is plainly admitted and obvious in itself that life could have existed, in the early twilight of our globe, before the fullorbed glory of the sun shone bright upon it, and while the young earth was still swathed in its swaddling bands of vaporous mist.

It is equally certain that the first simple forms of life were of necessity vegetative. This is at once clear from the fact that vegetation, in its simplest forms at least, was required for whatever other life might still follow. Hence the startling scientific correctness of the position occupied by the origin of vegetation in the sacred narrative.

Yet here again a word of caution must be spoken. It was certainly not the Divine purpose to compose a scientific treatise. The Sacred Scriptures were to have an equal appeal to the primitive peoples for whom they were first composed and the most highly cultivated nations history should yet know. If it was then the Divine plan to follow a strictly chronological order

2 "Genesis and Science," p. 40. 


\section{I26 EVOLUTION AND SOCIAL PROGRESS}

-a supposition we are in no sense obliged to maintain-the first appearance of simple vegetative forms at this period would be sufficient reason to offer at once the full account of the creation of the entire vegetative kingdom. The fact that almost equally simple forms of animal life apparently followed immediately upon the appearance of the earliest vegetative forms would not conflict with such a plan.

This should appeal all the more strongly to the evolutionist. If all plants have evolved from one single vegetative cell, then with the appearance of this one cell the entire vegetable world was there in its potentiality. Whether that cell was created or not is a question beyond the realm of science to decide, although reason proves that creation, as we have shown, is the only logical explanation.

The theory itself that all plants are derived from one single cell, can never of course be established scientifically. It is a mere surmise, without any evidence, an extreme venture that scientists were fast discarding in the nineteenth century itself. Should we, however, not only assume this much, but even proceed further and admit the still more fanciful and baseless assumption that all life forms are derived from a single cell, then that cell too must have been vegetative, and not as yet sentient, according to evolutionist principles. No, matter, therefore, what theory we assume, or 
how much anyone may wish to expunge the Creator from His works, the fact stands incontestable that vegetable life is found in the precise location in the Scripture account which modern science must assign to it, even to its appearance before the full sunlight would penetrate the mists. This, and no more, we desire here to maintain, without seeking to affix any scientific hypothesis to a Scripture text.

So then, with the creation of the first humble forms of vegetative existence, the entire scene is at once unveiled before our eyes by the inspired writer, as, on the evolutionary assumption, it was to unfold itself in the course of the unnumbered years. It matters not whether these are reckoned by the thousands or the millions. Thus only could the great fact be consistently told by the sacred scribe to a primitive people and yet retain all its truth for the most advanced worker in modern research. Here follows the Scripture account:

And the earth brought forth the green herb, and such as yieldeth seed according to its kind, and the tree that beareth fruit, having seed each one according to its kind.

We may add here that science has exceedingly little to tell concerning this earliest period of living organisms. Owing to the great changes that still continued to take place upon the earth's surface, their traces have been almost entirelv obe 


\section{28 EVOLUTION AND SOCIAL PROGRESS}

literated. All pre-Cambrian fossils that may once have existed were completely destroyed, and even the Cambrian remnants have almost entirely disappeared. "Should it be concluded from these facts," asks Depéret-Wagner, "that we must forever desist from hoping to solve a problem so passionately discussed as that of the commencement of life upon earth? Or at least to be able to follow it further back?" And he mournfully answers: "Unhappily it must be granted that this is the most probable prospect." 3 We behold therefore the absurdity of the bold and sweeping assertions made in the name of science where certainty is a thing utterly and forever unattainable.

But perhaps the most impressive fact of the entire Scripture narrative of the creation of heaven and earth, from a scientific point of view, is the description that now appears for the first time, of the sun, moon and stars, shining in the firmament of heaven, long after the creation of light itself. Here, as apparently throughout the entire narrative, the viewpoint is the earth surface from which all these events are pictured. To quote but the sixteenth verse:

And God made two great lights; a greater light to rule the day; and a lesser light to rule the night; and the stars.

How indeed could Moses have known, without

"Die Umbildung der Tiervelt," p. 312. See Karl Frank, S. J., "The Theory of Evolution," pp. 22-26. 
Divine Revelation, the fact which every scientist now admits, that light existed in the universe before the sun, moon and stars shone in the firmament of heaven? The full meaning of this revelation, we may well suppose, remained even then a mystery for him. He, like others, received it as the simple revelation of a fact accepted on unquestionable authority. Yet the sages of his day might well have scoffed at it, judging it by their shallow knowledge, while the incredulous might have pointed to it as an impossibility until science herself came to explain the truth. On this subject Col. Turton says :

The writer of Genesis places the formation of the sun after that of light. This must have appeared when it was written, and for thousands of years afterwards, an obvious absurdity, since everyone could see that the sun was the source of light. We now know that it is correct. But is it likely that the writer of Genesis had any human means of knowing this; or is it likely that without such means, he should have made such a wonderfully lucky guess? Either alternative seems most improbable, and yet there is no other, unless we admit that the knowledge was divinely revealed."

We now know, by science as well as by Scripture, that light preceded the sun, although the details of this knowledge are still most doubtful. After the creation of matter, after the first impulse given to the atoms in their vast ethereal spaces, the most primitive of all phenomena is by all held to have been the production of light.

4 "The Truth of Christianity," p. 154. 


\section{I3O EVOLUTION AND SOCIAL PROGRESS}

The light may have been of electric origin, as in an X-ray tube, since the depths of space form a very complete vacuum. Eons of years passed, we may well believe, between the shining forth of the immense solar nebula and the flinging off of the potential earth nebula, luminous with its own electric and compressional forces, and gradually growing cooler after condensation. The moon, too, whether detached from the earth's mass or from the solar nebula directly, gradually condensed, and in fact much sooner than the earth, since its size was much smaller.

But the moon could shed no light, as it now floated, cold and dead, in its orbit, until it had first been caught up in the brilliant radiance of the sun. Only then could the Scripture speak of the first appearance of this lesser luminary, at the same time that it mentions the sun and the stars. Here too we can therefore establish the perfect conformity of the Scripture account with the scientific chronology.

From the surface of the earth, also, the vaporous, deadening blanket had now been removed, an atmosphere had been formed and clarified until at length it became the transparent medium we know it to be at present. It was possible, therefore, for the light of sun and moon and stars to fall upon it. The first vegetative forms, as we have seen, could already have sprung up under the diffused light of an earlier period. The time 
had come when God would call into being the sentient creatures.

The scientific accuracy of what now follows is too apparent to call for long discussion. He who runs may read its verification in God's great volume, whose pages are the earth's strata, bound in their illumined cover of brown clod and green grass and varicolored flowers, like a missal made by some gentle monk's fine art, inscribed, illumined and bound, as a lasting work, for the glory of the great Creator. No scientist can question the accordance between the sequence of the remaining epochs of creation and that of the fossil evidence written in the rocks. The Book of Revelation reads like a perfect transcript from the Book of Nature. Yet the pages of this vast volume were not laid open in the Mosaic days, to be read as now we can read them. With seven seals was it sealed from every eye except that of God alone. How then could its writer have made his transcript, page by page, as it would now seem when we are able to compare the two?

God also said: Let the waters bring forth the creeping creature having life, and the fowl that may fly over the earth under the firmament of heaven.

And God created the great whales, and every living and moving creature, which the waters brought forth, according to their kinds, and every winged fowl according to its kind. 
Applying to these verses the chronological test of science, a science now not based on theory but on the undeniable evidence of nature, Sir Bertram Windle appositely says:

Here we arrive at the second milestone in the path of progress, for not only do we find ourselves confronted by life but for the first time with the sentient life, and, as already said, it is described at the place where science tells us that it might be looked for. Now here we have another agreement between the Scriptural and scientific accounts, for the evolutionists will certainly not deny that zoological life seems first of all to have originated in the sea; that it was preceded by the appearance of vegetable life; that fishes did come before birds and that the gigantic saurians-which it is suggested may have been intended by the Hebrew word commonly but probably incorrectly translated "whales"-were a very remarkable feature of the period of geological time at which we have now arrived, since some of them attained a length of at least fifty feet. It has also been pointed out that it is somewhat remarkable that the writer, of course unfamiliar with science, should have grouped birds with fishes and not with mammals, which would have seemed much more natural. Yet in doing so he is acting quite correctly.

We understand well enough that only the lowest types are found in the earliest strata, and that there is no sharply marked cleavage. Invertebrate animals appear long before the highly advanced vertebrate fishes. The inspired writer deals only with the perfect organisms and the highly developed forms of life. He was not to write a textbook of science, a discussion of vertebrates and invertebrates. His picture was necess"The Church and Science," pp. I8I, 182. 
sarily to be given in strong, bold lines, and in a language intelligible to all his hearers through the course of ages. Such was God's plan. Yet the broad succession of life-forms in the Scripture account is accurately the same as that which science teaches us it must have been: first vegetative organisms; then the primitive sea-worms, fishes and saurians; next the birds, and finally the fully developed forms of the land animals preparatory to the coming of man:

And God said: Let the earth bring forth the living creature in its kind, cattle and creeping things, and beasts of the earth, according to theit kinds.

It should again be understood, on the chronological hypothesis, which, as we have seen, is but one method of interpreting the narrative of the Creation, that as Genesis is not intended for a detailed scientific account, so science in its turn has only the most fragmentary records to offer. Thus it is stated that the fossils of reptiles are found before those of birds; it does not follow that reptiles actually preceded the birds in the order of direct creation or of evolution. The earliest birds, more delicate in structure, might more readily have been destroyed so that fossil tiaces could not be found of them. Here our knowledge is so utterly inadequate. Hence there could be no question, on such a supposition, of affirming any contradiction. We have but begun 
our discoveries, and we shall never be able scientifically to establish all the data for the beginnings of life. The earliest records, in fact, are almost completely destroyed, like the writings that have been effaced from a school-boy's slate, with but a curve or a dot remaining, here or there. It is the height of absurdity to speak of these questions with apodictic certainty, where even guessing is hazardous.

One other fact must still be stated here, and that is that the rocks of the earth themselves bear no direct evidence of any evolution. The various types, even among the early invertebrates in the Cambrian formation, appear "clearly separated into all the families and most of the classes which exist at present." 6 The same is true of the vertebrates. The fishes in the lower Silurian formation appear just as clearly separated from the invertebrates. "There are numerous quite different types existing, but separate from the beginning." 7 The first birds, though with certain reptilian characteristics, cannot be shown to have really descended from any particular reptile. The earliest mammalia are clearly differentiated, and we find them at the eocene period "almost as fully typified and as sharply defined as today, particularly such as were of unusual size or of pe-

"Karl Frank, S. J., "The Theory of Evolution," p. 30.

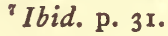


culiar traveling powers or habits of life." 8 That higher classes are descended from these is therefore "in no single case other than probable," or as Darwin says in the words previously quoted, we cannot prove the evolution of even one single species into another. ${ }^{9}$ The word species must, as further stated, be taken in the strict sense in which Darwin there understands it, and not as a mere variety. The same concession, we also saw, was made by M. Yves Delage of the Sarbonne, and other leading evolutionists.

The distinct species, in other words, everywhere appear suddenly. The transitions traced in science primers, are often merely apparent and it is found, as in the stock example of the horse, that the beautiful gradational forms usually pictured for the instant conviction of the unsophisticated student could not possibly have succeeded one another. The following authoritative passage from A. Sedgwick, dealing with this classic example, which was long regarded as the triumph of evolution, in so much as this was based upon the supposed evidence of intermediate links, deserves to be repeated here:

So far as the characters mentioned are concerned, we have a very remarkable series of forms which at first sight appear to constitute a linear series with no cross connections. Whether, however, they really do this is a difficult point to

'Steinmann, "Die geologischen Grundlagen der Abstammungslehre," p. 233. (Frank p. 33.)

"Life and Letters of Charles Darwin," I, p. 2 ro. 


\section{I36 EVOLUTION AND SOCIAL PROGRESS}

decide. There are flaws in the chain of evidence, which require careful and detailed consideration. For instance, the genus Equus (horse) appears in the upper Siwalik beds, which have been ascribed to the Miocene age. It has, however, been maintained that these beds are really Lower Pliocene or even Upper Pliocene. It is clear that the decision of this question is of the utmost importance. If Equus really existed in the Upper Miocene, it was antecedent to some of its supposed ancestors.

Again, in the series of equine forms, Mesohippus, Miohippus, Desmathippus, Protohippus, which are generally regarded as coming into the direct line of equine descent, Scott points out that each genus is, in some respect or other, less modernized than its predecessor.

In other words, it would appear that in the succession of North American forms the earlier genera show, in some points, closer resemblance to the modern Equus than to their immediate successors. It is possible that these difficulties and others of the same kind will be overcome with the growth of knowledge, but it is necessary to take note of them, for in the search after truth nothing is gained by ignoring such apparent discrepancies between theory and fact. ${ }^{10}$

It is not as an attack upon the theory of evolution that these statements are quoted, for the purpose here is neither to attack nor defend, but to make plain the truth which has too often been studiously overclouded. The fact is that nothing can be known with certainty in this matter, even where we are dealing with what is apparently the most obvious evidence, as in the present instance.

All that we can say is that the various clearly distinct species appear abruptly in their geologi-

20 "Student's Text Book of Zoology," II, p. 600. 
eal layers, as definitely characterized types. Sir William Dawson quite correctly writes:

The compound eyes and filmy wings of insects; the teeth, bones and scales of batrachians and fishes; all are as perfectly finished, and many quite as complete and elegant as in the animals of the present day.... At one time it is broadleaved forest trees that enter upon the scene, altogether different from those that went before; at other times, lizard-like reptiles, birds and mammals, each stamped at its first coming with the essential characteristics of its class as we know it today; so that it is impossible, except by violent suppositions, to connect them genetically with any predecessors. ${ }^{11}$

Hence it was possible for a really eminent biologist, such as Professor Fleischmann certainly must be reckoned, entirely to reject the evolutionary theories in the day of their full glory. Hence, also, it was possible for other independent thinkers to come to the conclusion that the facts of nature do not give any evidence of gradual evolution, but rather must be explained away in favor of it. On this important point Father Hull writes:

Attempts have been made to arrange in order the gradual evolution of the different species from the lower to the higher, and from the simpler to the more complex. The genealogical tree thus produced, both for the plant and the animal orders, almost overwhelms the mind with a conviction of its truth, until we begin to realize how much speculation and guesswork have beeen mixed up with fact in the formation of the pedigrees; and moreover, how difficult it is to imagine the process by which the larger divisions of vegetable and animal types can have passed over the dividing line between one and another.

A student who recently took his doctorate of biology in Berlin "11 "Modern Ideas of Evolution." 


\section{I38 EVOLUTION AND SOCIAL PROGRESS}

told me that on account of these difficulties and gaps the most profound of his professors, while adhering faithfully to the evolution theory as a theory, acknowledged that as soon as one begins to examine the process in detail, the difficulties are simply unsurpassable, and the transitions become in some points even unthinkable. Hence we are far from having reached the point where the evolution-theory is even promising to pass from the region of the hypothesis into the region of ascertained fact.

To the Scripture scholar, we need not repeat, it is a matter of indifference whether the successive species hitherto described in the Sacred Text were created directly, or through the even more wonderful medium of evolution, according to laws divinely foreordained and imprinted on the originally created elements. Certain restrictions, as we have seen, are to be made, which science and reason postulate, nor do we wish here to anticipate what is still to be said of the specific creation of the first human beings. The old theory of a gradual transformation of species, we have also shown, was widely discarded by scientists at the beginning of the twentieth century in favor of the "saltatory theory," popularized by De Vries, which calls for the sudden and not for the gradual appearance of the new species. It was thus a complete reversal of the position of the older evolutionists, once considered unassail able. For the present it suffices to have pointed out what agreement there exists between the fact: of science and the actual sequence of creative acte in the order in which we find them recorded in the 
Scriptures. The comparison draws from Col. Turton the following striking remarks :

The points of agreement between Genesis and science are far too many and far too unlikely to be due to accident. They are far too many: for the chances against even eight events being put down in their correct order by guesswork is 40,319 to one. And they are far too unlikely: for what could have induced an ignorant man (i.e., ignorant of modern science) to say that light came before the sun, or that the earth once existed without any dry land. ${ }^{12}$

Finally, we now arrive at the detailed description of the creation of man. It follows in the last place; precisely again where science demands that it should be placed:

And God created man to his own image: to the image of God he created him: male and female he created them.

This image of God is to be found in the rational soul of man whereby he is essentially distinguished from all the other animal creation. The body of man was made from preexisting matter, whether by evolution or not we shall consider in the following chapters. The soul called for a new creative act. Between the thoughts of man and purely physical or chemical reaction, between the intelligence of man and the mere instinct of the brute animal, there is a chasm which no evolution can bridge. As the existence of matter and the laws that govern it were impossible without a first cause outside of nature, a supreme intelligence, ${ }^{12} \mathrm{Op}$. cit., p. 184 . 
self-existent of its very essence; as the origin of life without this first cause is not merely incomprehensible, but the very thought of the development of living organisms from dead matter is repugnant to our reason; so now there is no other manner of accounting for the intelligent soul of man except by a special creative act. The same cause that called matter into being and gave the force that impelled it into motion, directing its development by laws which none but the maker of them should ever be able to set aside; the same cause that was able to bring into a world of dead matter, "void and empty," the first spark of life and fill it with the wonders of its animate creation; that cause alone could now, by a new creative act, call into being the intelligence of man which might utilize, rule and direct the entire creation, and lift up its song of praise and thanksgiving to the supreme Creator. This great creative act the sacred writer clothes in language beautiful and poetical in its rich symbolism, picturing in delight fully human ways the invisible and pure spirit that is God:

And the Lord God formed man of the slime of the earth: and breathed into his face the breath of life, and man became a living soul.

So we close our account. We have thus studied the opening chapters of Genesis as recounting a series of geological and biological events on the earth's surface, viewing them from a purely scien- 
tific aspect and following a strictly chronological order. While Scripture interpretation did not constrain us to adopt this method, but left open many avenues of perfectly legitimate explanation which would not have necessitated a strict sequence of time, yet the fact remains that such sequence can be traced, in full conformity not only with certified scientific facts, but even with reliable scientific theories. Our most advanced knowledge, in brief, has afforded us startling explanations of the Mosaic narrative whose truth is beyond all peradventure of doubt, though its history is often clothed in a majestic symbolism. So out of the mouths of babes and sucklings can be given the most perfect praise of God, and primitive peoples can understand in its full scope the lessons of that Scripture narrative, which has filled with wonder the profoundest minds. ${ }^{13}$

Perhaps we can now more fully understand what the great Ampère meant when he spoke those words we quoted at the first: "Either Moses knew as much about science as we, or else he was inspired."

${ }^{13}$ See Muckermann, S. J., "Variabilität und Artbuildung in Natur und Offenbarung." 


\section{H A P T E R X I I}

\section{'MAN'S REPORTED ANCESTRY}

T $\mathrm{T}$ was August I4, I90I. The Fifth International Congress of Zoologists had just closed 1 at Berlin, and the members were on their way to visit the Zoological Garden. An attendant was there awaiting them, with two young chimpanzees resting on his arm. They were to welcome the learned guests and greet them as their near bloodrelatives and comrades. "The two little apes grinned at us with cheerful confidence," writes Father Wasmann who had attended the convention, "as if they were fully convinced that we believed in the theory of evolution, and would like to invite us to shake hands in recognition of the bond existing between us. But I thought to myself: 'No, my dear little creatures, thank God, we have not yet come to that!" "1

Yet it is precisely to this that the world did come in its philosophy of Socialism, its popular literature of science and sociology and its rationalistic higher education. Without a single demonstrable proof that can stand the test of scien1 "Modern Biology," pp. 479, 480. 
tific investigation, the descent of man from the ape was set down as an unquestioned fact in a thousand manuals that were made the text for atheistic propaganda to the ruin of modern civilization. Created to the image and likeness of God, man was taught to consider himself, body and mind, as one in origin and nature with the brute. No longer of God, godly, he was now of the earth, earthy; of the beast, beastly, unless his better nature, with the help of Divine grace, lifted him above the lessons taught in school and in the press. There could no longer be any valid rule of conduct, we have shown, except instinct, inclination and expediency. All higher forms of morality, no matter in what roseate language of humanitarianism they might be clothed, would of necessity remain without sanction or foundation. Men could be true and noble only in spite of their instructors, or just so long as the old influences and traditions should still remain effective.

It will be well here to begin by taking a glance at a few of the dogmatic utterances so common among sociologists and scientists in the past, no less than among literateurs and journalists. Not the slightest indication is given by many of these writers to the unwary pupil or to the curious reader, of the perilously unstable equilibrium of their unprovable theories. It is true that in the second edition of his "Natürliche Schöpfungsgeschichte," Haeckel wrote in allusion to his fabu- 


\section{I44 EVOLUTION AND SOCIAL PROGRESS}

lous pedigrees of man: "On this occasion, as well as with reference to my other hypotheses regarding evolution, I protest against having any dogmatic significance ascribed to them. They are merely first attempts." 2 This might be considered a modest statement of the plain fact that there is no proof for the evolution of man, but it can be wrung from men like Haeckel only when placed with their back to the wall. In his "Welträtsel"- "The Riddle of the Universe"Haeckel again deliberately resumes his habitual attitude of dogmatism, and worst of all he was taken seriously, by those at least who wished to believe in his conclusions:

In the last twenty years a considerable number of wellpreserved fossil skeletons of anthropoid and other apes have been discovered, and amongst them are the important intermediary forms, which constitute a series of ancestors connecting the oldest anthropoid ape with man. ${ }^{3}$

Could a more positive dogmatism be conceived on a matter on which science has absolutely nothing to offer that can amount even to an approach towards evidence. The reason for such statements, as Kellogg admits, is mainly subjective. Man must be descended from the ape, body and mind, because materialistic evolution requires this, and materialistic evolution must be true, because else it would be necessary to admit a Creator. This is the main line of subconscious, and often of

"See Wasmann "The Problem of Evolution," p. 190.

3 "Welträtsel," p. 99; Wasmann, op. cit., p. r9r. 
explicit argument on which the final positive dogma of "a series of ancestors connecting the oldest anthropoid ape with man," is ultimately based. The few isolated facts of science can establish no such definite and absolute conclusion. The great biologist Reinke, whose authority no one can challenge, thus disposes of the question:

We merely have dust thrown in our eyes when we read in a widely circulated book by Ernst Haeckel ("The Riddle of the Universe") the following words: "That man is immediately descended from the apes, and more remotely from a long line of lower vertebrates, remains established as an undoubted historic fact, fraught with important consequences." It is absurd to speak of anything as a fact when experience lends no support to it. ${ }^{4}$

Nowhere can the happy verses of Mr. Arthur Guiterman find a better application than in describing the methods by which the propaganda of materialistic evolution, especially in regard to the supposed descent of man from the ape, has been sedulously carried on. There would have been no need whatsoever of writing the following rules for Haeckel and his class of propagandists, so perfectly were they carried out by them to the very letter:

When the situation clamors for a pardonable lie,

Please begin your observations with, "As No One Will Deny."

With a modest little, bashful little effort to deceive,

Kindly use the introduction, "We Have Reason to Believe."

4 "Haeckel's 'Monism and Its Supporters," p. 6; Wasmann, op. cit., pp. 8o, 8r. Note. 
I46 EVOLUTION AND SOCIAL PROGRESS

When the information's doubtful, be no whit dismayed thereat,

Finding refuge in the sentence, "'Tis an Open Secret That_-"

You may search the very marrow of your controversial foes

With that phrase of cold disparagement, "As Every Schoolboy Knows."

And a fraud will seem as pious as a missionary tract With the prefatory label, "It Is an Undoubted Fact." ${ }^{5}$

Delightful illustrations of all this can be found in countless books of sociology and science, not to mention the Sunday supplements, where discussions on evolution are likely to belong to the same category as the loudly colored pictures of the "funny page," though their results may be far from ludicrous.

The philosophy of Socialism is of course built entirely upon this same unsubstantial foundation. Karl Kautsky, considered in the official organ of American Socialism as the foremost exponent of Socialist morality, bases his volume on this latter subject ${ }^{6}$ almost exclusively upon the "social" conditions existing in the animal world, upon the life of the "man apes" and the herding beasts. The use of tools on the part of the ape, which he illustrates by the wielding of the branches of trees in self-defense and the cracking of nuts with stones, are said to denote the first approach towards human development. "With the pro-

5 "Rules for Editorial Writers," in "The Mirthful Lyre."

"Ethics and the Materialistic Conception of History." 
duction of the means of production the animal man becomes the human man." 7 All Socialist philosophy is based upon Morgan's materialistic and purely imaginary evolution of man. Both Engels and Bebel transcribe his doctrines literally. Dwelling upon the infancy of the human race in his "Origin of the Family" the former says: "Human beings still dwelt in their original habitation, in tropical or subtropical forests. They lived at least part of the time in trees, for only in this way they could escape the attacks of large beasts of prey and survive. Fruit, nuts and roots served as food. The formation of articulate speech is the principal result of this period." 8 $\mathrm{He}$ admits we have no direct evidence of the existence of this stage of human evolution. "But," he adds, "once the descent of man from the animal kingdom is acknowledged, the acceptance of this stage of transition becomes inevitable." 9 Such an acknowledgment he takes as a matter of course.

The same entertaining story has for years been offered the public in films and Sunday supplements. "How the monkey began to be a man is a story that has been worked out in a fascinating, scientific manner by Doctor William K. Gregory of the American Museum of Natural History, Manhattan," ran a report in the Brooklyn Eagle. He

IIbid., p. 120.

8 "The Origin of the Family," p. 27.

Ibid., p. 28. 
sees in the gorilla man's nearest relative, points out certain bodily similarities which are not new to us, alludes to the ape's clumsy attempts at walking erect, and then continues:

In the same way the ape that would be a man, and who in a thousand generations succeeded in that ambition, started to leave the sheltered woods by degrees and with hesitating steps. $\mathrm{He}$ and his wife, the real Adam and Eve, made their home in a tree-their house a sort of bird's nest arranged of branches in a suitable crotch, the thick foliage overhead serving as a roof. $^{10}$

So the tale continues as we have read it a thousand times before, and it should certainly be true if constant repetition could make it so. Oc. casionally an interesting originality is displayed by these writers, as when Professor G. F. Scott Elliott, M.A. (Cantab.), B.Sc., (Edin.), F.R.S.E., F.L.S., F.R.G.S., who is far less extreme than many another writer upon these subjects, and even refers us to "the oldest and most widely read of all books" for an answer to the difficulties that perplex the scientist, yet assures us that it is quite possible to give "a rude, blurred picture of the Pliocene precursor (of man) when he was just on the point of venturing on the great step upwards." This he at once proceeds to do:

His body would be covered with hair or fur, except on the palms or soles of his feet. On his head the hair grew long and thick, and was continued in all probability down his cheeks and chin to form a combined beard and whisker fringe. We do ${ }^{10}$ Reported in Brooklyn Eagle. 
not think he had much of a mustache, but probably his eyebrows "beetled." The hair was wavy or curly; it may have had a tendency to be lank, straight, and stiff on the head, but this is doubtful. It was not so woolly as that of the negro. His children probably had a rich Titian red or bronzy coat of fur, like that which one sees on young Galloway cattle. In the epidermis (vulgarly the outer skin) as well as in the hair were both black and orange pigment, but on the whole he was probably moderately dark-skinned. ${ }^{11}$

The most delicious part of the description, here quoted in part only, is the conscientious qualification, "But this is doubtful," applied to the stiffness of the hair upon the head. All else is apparently certain. The reason for selecting both "black and orange pigment" for the skin and hair of the furry Pliocene babies, who were to be the proud forefathers and granddames of our race, is thus given in the footnote: "Changes of this character occur in the pelage of some monkeys and lemurs-Pithecia leucocephala, Mycetes caraya, Lemur macaco."

So the subject is settled forever, the case is closed, and who would dare to raise a doubtexcept for that one exquisite particular: the stiffness of the mossy hair on the ancestral head: "dark thick hair," amid which "the little ape-like ears could hardly be seen." His nose, all that there was to it, was "of the most retroussé." Even the minutest habits of the early social and domestic life of this noble, though "slightly bandy-

t\# "Prehistoric Man and His Story," pp. 58, 59. 


\section{I5 EVOLUTION AND SOCIAL PROGRESS}

legged" precursor of our human race, have been carefully noted and set down:

At the night he would retire to a roughly woven nest in the branches of a tree. When sleeping, his head would be bent forward over his wrists; these would be crossed in front of his chest, with elbows down and outwards. His legs would be strongly bent or flexed, so that the knees were also near the wrists. His waist measure would be excessively small, or he could not assume this position, which is, as a matter of fact, hardly possible, and certainly painful for civilized man. On a similar nest, close by, would be his wife or wives, with Titian red or bronze babies sound asleep, and yet clinging round their mother's neck. ${ }^{12}$

This last touch of nature, that makes the whole world kin, must surely win over even the most obdurate opponent of what we no longer dare to call the "theory," but must plainly call the "history" of the descent of man from the brute, if we would accept the author's statement on his own valuation. A shudder may possibly pass through us as we think of the venerated head of our honored ancestor exposed to the raging gale and driving rain of a stormy night. But our filial fears are at once completely calmed when we are solemnly assured that: "The rain would be conducted away by his hair and his beard, by his elbows and hipjoints, so as to drip nearly clear of his face and body." So too in the sultry summer evenings "the tangled labyrinthine masses of chevelure" protect him from midges and mosquitoes. There is more reason therefore to compassionate our ${ }^{12}$ Ibid., pp. 59, 60. 
own poor selves, who in many ways appear to be the degenerate descendants of such a sire. And yet Professor Elliott elsewhere makes statements. that are more conservative than those of many another writer upon this subject.

So the first page of social history is written. On such a basis the philosophy of Socialism, of much of our modern sociology, and of "ethical" education in the rationalistic class-room is built. For the convenience of those who may wish to climb the ancestral family tree of the human race - the figure is well chosen-the great high priest of this phase of materialistic evolution, Ernest Haeckel himself, has pointed out the trunk they must ascend: the direct central line consisting of half-apes, true apes, and imaginary apes from which we are supposed to have evolved. For forty years he labored at this "Pedigree of the Primates" whose genealogy is given by him down to the last missing link. ${ }^{13}$ Its nature and value can be accurately gauged by the following scientific review :

As man's most remote ancestor Haeckel gives the Archiprimas, a purely imaginary form. From him are descended the Pachylemures, represented by the universally accepted $L e$ muravida. Next come the Necrolemures, of whom nothing very definite is said. From them, according to Haeckel, are descended the apes, one of whom in particular, the Archipithecus, is the ancestor of man-this is again a product of the imagination. The Prothylobates is a direct descendant of the Archipithecus, but he too never had any existence, and has

${ }^{13}$ Haeckel, "The Struggle Regarding Evolution," p. 99. 


\section{I52 EVOLUTION AND SOCIAL PROGRESS}

been invented. From him is descended the Pithecanthropus alalus, the speechless primitive man. He could not be called Pithecanthropus erectus, because scientists had already excluded this from the list of man's direct ancestors. So Haeckel called him the speechless primitive man; but he too is an imaginary being. Next to him we have the Homo stupidus, the stupid man who is a very real creature, and from him at last we arrive at the Homo sapiens. ${ }^{14}$

Such is the solemn and grandiose nonsense that in the name of science was so long perpetrated upon the world and was received with worshipful credulity in our halls of learning by the men who could not accept the authentic revelations of God and the most rational doctrines of His Church. But what then is the scientific evidence, certain and incontrovertible, for the descent of man from the ape? Expressed in one word, it is zero. What the sparse scientific facts are on which these theories are built we shall sufficiently indicate in the following pages. The results we may briefly anticipate in the words of Virchow spoken in his Inaugural Address at the Wiesbaden Congress of Naturalists, when he said of the study of prehistoric anthropology:

"Every positive advance which we have made in that study removed us further than before from any proof of evolution to be found there. Man has not descended from the ape, nor has any apeman existed."

${ }^{24}$ Wasmann, "The Problem of Evolution," pp. 79, 80. 


\section{THE MISSING LINK}

7 HAT the question of the descent of man from the brute belongs purely to the 1 realm of theory and not to that of established fact cannot be seriously disputed. It is evident from the simple circumstance that no uniformity of opinion has ever existed among the very scientists who have most enthusiastically promoted these views.

There are in the first place those who defend a direct relationship between man and the ape. These have found their supporters largely among zoologists, and their theories are in general blindly reproduced in the literature of Socialism and in popular works of sociology, in class manuals and books of general information. Others claim to find man's primitive ancestor in some lower order of mammals. Thus the hypothetical Molchmaus was invented to answer this purpose. The latter view won greater favor among anthropologists, but the former, because more speciously alluring, was more readily adaptable for general propaganda. 


\section{54 EVOLUTION AND SOCIAL PROGRESS}

The argument that naturally appealed most to the popular imagination was that founded on the theory of the missing link. Many forms of the "ape-man" were forthwith discovered, but after carefully studying them all, the great paleontologist Branco, the special authority in this very field, announced at the Berlin International Congress of Zoologists, in I9OI, as the result of his thorough investigation that: "Paleontology tells us nothing on the subject. It knows no ancestor of man." 1

The first specimen logically to be considered here, although not the first discovered, is the socalled Pithecanthropus erectus, or "walking apeman." From an elaborate bust of him, fancifully conceived and cleverly executed, the uninformed reader might well be led to believe that he had been found like the mastodon embedded in the ice, and so had come down to us, perfectly preserved for our admiring vision, even to the shaggy hair on breast and arm. With dignified mien and huge flowing side beard, he is a being patriarchal, almost venerable, in spite of slightly protruding tusks and simian jaw. Looking forward with uplifted head, placid eyes and serene countenance, he seems to be gazing into the future of his race.

Turning now from theory to fact, from imagination to reality, what is it that science itself has

${ }^{1}$ See Wasmann "Modern Biology," p. 478. 
to tell us? The entire foundation for this fanciful imposition upon the simplicity of pupils, the ignorance of the unlettered and the credulity of the schools consists in the upper portion of a skull, two molar teeth and a thigh bone found scattered forty-six feet apart in an old river bed in Java. It is not even known whether these scattered relics belonged to the same individual. It is quite certain in fact that they did not. In I89I one molar tooth was found, and later at a distance of about three feet, a fragment of a skull. The following year, after laborious researches in the same vicinity, the thigh bone was discovered at a distance of about fifty feet from the former location and nine feet from this bone the second molar tooth lay embedded.

When Dubois, who had made the discovery, read his paper before the Congress of Zoologists at Leyden, in 1895 , the famous scientist Virchow, who presided, commented upon the speaker's ingenuity, but concluded that it was impossible to say whether the fragments belonged to one individual or to more, and whether they were simian or human. The skull itself he pronounced to be simply that of an ape. No other bones were found in that locality in spite of a five years' search, and no one can tell whence these may have been washed into the river bed. Virchow later confirmed his opinion that the skull was that 


\section{I56 EVOLUTION AND SOCIAL PROGRESS}

of an ape. In regard to the whole question the scientists of note were most completely divided in their judgment upon every single one of the four bones.

It was not even certain to what geological epoch the layer of earth belonged in which these remnants were found. Scientists at first claimed they dated back to Pliocene times, until the opinion gradually gained ground that they were of Pleistocene origin. It is needless to enter into the battles that were fought by scientists in regard to every detail connected with this handful of bones. It was all a question of nationality, the witty French archæologist G. de Mortillet suggested. The English stood by Darwin in their interpretation. The Germans said it was an ape, and the French defended their own young countryman who had made the discovery. This is somewhat of an exaggeration, but correctly indicates how far all these discrepant views were merely a question of bias and not of science. Yet out of this dust of scuffling feet and confusion of swinging arms and clenched fists, leaving nothing for the basis of a single final judgment, the imagination of the artist evokes the picture we have described, Pithecanthropus erectus, the walking ape-man, and for years the pupils in our schools and the general public in its magazines and papers, its sociology and popular literature are deceived into believing 
that here indeed has been found the earliest specimen of the missing link. ${ }^{2}$

Regarding the skull alone of this specimen a scientific writer offers a list of twenty leading opinions. Of these "authorities" seven pronounced it to be human, seven believed it to be transitional, and six held with Virchow that it was simply the pate of an ape. ${ }^{3}$ It may be considered sufficiently certain that the skull belonged to an ape of great size, which will adequately account for the brain capacity. Hertwig says: "The opinion that is most probably correct is that the fragments belonged to an anthropomorphic ape of extraordinary size and an enormous cranial capacity." 4 It is needless to quote further details where we are plainly in a land of guesses and surmises. The evolutionary bias alone suggested the idea that here might have been found an intermediary form. Evidence there is none.

Neither, finally, is there any evidence whatsoever for placing these remnants in the Tertiary period, and Branco in 1908 assigned them to about the middle of the Pleistocene epoch. This makes them contemporaneous with man, and completely destroys the entire hypothesis.

But evolutionary hypotheses must be sustained

${ }^{2}$ On this subject see Windle, "A Century of Scientific Thought," pp. 155, I57 and pp. 185, 196; also Wasmann, "Modern Biology," pp. 465, 467.

${ }^{8}$ Dr. Munro, "Palæolithic Man," p. 190.

"Richard Hertwig, "Lehrbuch der Zoologie," sixth edition;

Wasmann, p. 466. 
at all hazards, and so eolithic man was invented, as the first in the chain of missing links. No remnants of him were ever found, but he was known to have existed. For proof we were shown rough flint chippings said to have been made by early Tertiary man and to correspond to the first periods of dawning reason. Real science has since shown in the person of Abbé Breuil 5 how these fragments, known as "eoliths," are broken off in the ordinary process of nature by the settling of the strata. De Lapparent calls them silex tailles par eux-mêmes. And so another fair dream of the evolutionist, Rutot's discredited eolithic theory, is dispelled and with it should go the still more purely fanciful Homosimius precursor. Since it is admitted on all hands that these stones can be and are produced by purely geological means, it is obviously unscientific to ascribe them to an imaginary earliest savage apeman. Yet the temptation is too strong, and so we still find him introduced to us by Scott Elliot with an innocent "suppose" which in popular literature at once becomes superfluous:

Suppose that Homosimius precursor, which is the correct name for Oligocene man [notice how the existence of an ape-man at this period is taken for granted] had ventured on the rocks at low tide and is busy with his eoliths, crouching on all fours. $\mathrm{He}$ catches sight of some dangerous beast about to attack him. Homosimius at once stands up as well as he could, which in itself would alarm the animal, and throws two or three stones

' "L'Anthropologie," Vol. XXI, p. 385. 
at it. This would at least for a moment or two check and puzzle his adversary.

There is no need of entering into discussion here about the Piltdown skull and the Heidelberg jaw. ${ }^{7}$ The former is clearly a human skull, beneath which our evolutionary reconstructionists painted the face of a chimpanzee, and so, according to Professor Keith, ${ }^{8}$ produced an impossible animal that could neither breathe nor eat. Klaatsch, Hertwig, Macnamara, Branco, Schwalbe and others equally rejected this reconstructed "Pilt-down man." Part of a jaw was likewise found at Piltdown which resembles the Heidelberg jaw, and both are believed to be human, while the teeth in them are said to be less ape-like than those of some of the savage races of our day. The massive development of the Heidelberg lower jaw was paralleled by Wasmann in a modern Eskimo skull. ${ }^{9}$ The similarity is noted also by Kramberger. So, too, the Piltdown skull is not inferior to the skulls of men living now. As for the evolutionary theory of a missing link, nothing is proved by these specimens. The same may be said of every other specimen. Sir Bertram Windle appositely quotes the words of Virchow, spoken at the twentieth congress of the German

- "Prehistoric Man," p. 29.

"See Windle, "A Century of Scientific Thought," pp. 188, I91.

"Ancient Types of Man."

" "Modern Biology," pp. 506, 507. 


\section{Anthropological Association, words that still remain final:}

No one doubted (at the first general meeting of the German Anthropological Association) that the proof would be forthcoming demonstrating that man was descended from a monkey, and that this descent from a monkey, or at least from some kind of animal, would soon be established. This was a challenge which was made and successfully defended in the first battle. Everybody knew all about it and was interested in it. Some spoke for it; some against it. It was considered the great question of anthropology. Let me remind you, however, at this point, that natural science, so long as it remains such, works only with real existing objects. A hypothesis may be discussed, but its significance can be established only by producing actual proofs in its favor, either by experiments or direct observation. This Darwinism has not succeeded in doing. In vain have its adherents sought for connecting links which should connect man with the monkey. Not a single one has been found. The so-called Pro-anthropos, which is supposed to represent this connecting link, has not yet appeared. No real scientist claims to have seen him. ${ }^{10}$

Virchow never changed, and never had reason to change his opinion. "The Pro-anthropos does not exist," he declared with emphasis at a later period, "the man-ape does not exist; the missing link remains a phantom." And every true scientist must agree with him. Such, too, was the testimony of the famous paleontologist Banco, already quoted. Here then is the evidence of two

${ }^{10} \mathrm{Pp}$. I54, I 55. The statement that Virchow's "vast knowledge and range of thought have been somewhat neutralized by his excessive conservatism," is merely another way of saying, as Windle rightly interprets it, that Virchow had not the good sense to agree with these gentlemen when they leaped to rash conclusions. 
of the greatest authorities in their respective fields.

But what of the Neanderthal man? $\mathrm{He}$ was constructed from an incomplete fragment of a skull found in a cave of the Neanderthal, near the Rhine, in 1857. Schwalbe in 1904 named him the Homo primigenius. In I90I the same author had submitted the skull to a close examination and quoted eleven different scientific opinions regarding it. It was held by various representative authorities to be the skull of an idiot, of a Kossack, a Celt or a German, a Dutchman or a Frisian, some claiming it belonged to a still existing race and others to an extinct race, and some regarded it simply as a freak of nature. It was finally looked upon as simply the skull of some ancient human race, not specifically different from ourselves. ${ }^{11}$ Even Huxley insisted that it represented no intermediate form. The difference of cranial capacity between the Neanderthal man and a present Australian negro was shown to be exceedingly slight. He was in brief a true man and many specimens of skulls and skeletons have been found that would seem to belong to the same race, i.e. the men of Le Moustier, of whom Bertram Windle says:

And what do we know about them? In the first place we know that they were men in every sense of the word, and big${ }^{11}$ See Wasmann, op. cit., pp. 467, 476; Windle, op. cit., pp. 148, 149 . 


\section{I62 EVOLUTION AND SOCIAL PROGRESS}

brained men too, since the cubic capacity of their skulls is greater than that of the average European of the present day. In the second place we know that they had the hands of men, since they fashioned, with the utmost skill, wonderful implements of flint, and in the third place, we know that they believed in a soul and a future life for that soul, for the very earliest interment known, that of the valley of the Chapelleaux-Saints, is one with those "accompanying gifts" which all the world over have but one significance: namely a belief in the after life and a desire to provide the spirit of the dead person with objects useful to it in that life. ${ }^{12}$

A further discussion of this subject will be found in the seventeenth and eighteenth chapters of this volume. But for the present it suffices to say that all that science has to tell us is that during the later Pliocene epoch a race of men existed in Central Europe who differed from the present Europeans in certain unessential characteristics, which, as Klaatsch has pointed out, may all be found today in the Australian negro. These peculiarities consisted mainly in heavy ridges over the eyes, explained by him as connected with the greater development of sight on the part of the paleolithic man, owing to his life as a hunter; in the massive receding jaws adapted to coarser food, and a lower forehead. There is nothing exceptional in the earliest specimens of men that we cannot parallel today in living human beings. ${ }^{13}$

In fine we may quite appositely conclude with the words of Professor Zittel, who in referring to

\footnotetext{
12 "Facts and Theories," p. I25.

${ }^{13}$ Wasmann, op. cit., p. 507.
} 
the more recent discoveries, concludes: "Such material as this throws no light upon the question of race and descent. All the human bones of determinable age that have come down to us from the European Deluvium, as well as all the skulls discovered in caves, are identified by their size, shape or capacity as belonging to Homo sapiens (true man). They do not by any means fill up the gap between man and the ape." 14

Is it not wonderful then and wholly inexplicable that in the face of all these facts, the textbooks of science as well as sociology should still have repeated by rote the same hopeless strain of dogmatism in affirming the undoubted existence of the fabulous missing link, who, so far as science is concerned, must be classed among the griffins and the wiverns and the Loreleis? Thus in his textbook of Zoology (I904), Adam Sedgwick continues this system of mythical classsification with the most positive assurance, as if no one had ever even questioned it:

Man is not known fossil till the Pleistocene. $\mathrm{He}$ is there represented by $H$. Sapiens, and by an extinct species, $H$. primigenius, Schwalbe, (neanderthalensis) from the Neanderthal (1856), from Spy (1885), and from Kapina in Croatia (about 1899), and possibly from other localities. This extinet species is not thoroughly known, but it clearly belongs to a lower grade of organization than $H$. Sapiens.

Peace to its memory! After the most careful study of the human skull, brought into such notice " "Outlines of Paleontology," p. 37. 


\section{I64 EVOLUTION AND SOCIAL PROGRESS}

by the Neanderthal specimen, Windle contributes the last word to this subject when he writes: "So far as craniological evidence goes, those who desire to prove the evolution of man's body from that of a lower form have completely failed to make out their case." 15 Even Macnamara, defending the descent of man from the brute, was obliged to admit upon the evidence furnished by certain Australian and Tasmanian skulls that: "The average cranial capacity of these selected thirty-six skulls is even less than that of the Neanderthal group, but in shape some of these two groups of crania are closely related." 16 The size of the brain is no accurate index of the intellectuality of its owner, and skulls with very large brain capacity are found in the earliest strata. Thus comparing a group of skulls of neolithic man with those of modern -Parisians Broca offers the following measurements :

No. Men No. Women Differences. Neolithic man .. $6 \quad 1606$ cc. II $6 \quad 1507$ cc. II 99 cc. Modern Parisian 77 1559 cc. I| 41 1337 cc. \|| 222 cc. $^{17}$

If therefore skull capacity were a decisive test of intellectuality, Parisians of the nineteenth century, when these measurements were taken, had been inferior to their predecessors of the stone age.

${ }^{15}$ See Windle's chapter "The Form of the Human Skull," in "A Century of Scientific Thought."

${ }_{10}$ Archiv für Anthropologie, XXVIII, r. 358.

${ }^{17}$ Windle, p. cit., p. 128. 


\section{DOES LIKENESS PROVE DESCENT?}

$7 \mathrm{HE}$ first argument given for the descent of man from the ape, or some other vertebrate, is naturally drawn from morphology. This calls attention to a certain obvious similarity in the structure of the skeleton, of various organs and of the nervous system. That many such resemblances exist between man and the higher animals no one would wish to deny, but the conclusions drawn from these facts are very deceptive and illogical. Man, in his bodily structure, was created as the most perfect of the mammals, but from this, of course, it does not follow that he must have descended from them by a process of evolution.

Accepting the fact of a Creator, nothing could be more comformable to His plan of a harmonious design for the great work of Creation, than that there should be a similarity such as even the architect of a Gothic cathedral would necessarily aim at to give unity to his design. The development, as we may say, of one sublime creative idea, harmonized perfectly in all its parts, beginning with 
the inorganic world and rising by wonderful gradations to its climax in man, constitutes for the Christian the great beauty of the universe that God has made. Similarity amid endless variety is the triumph of art. In itself, therefore, this similarity of design in nature gives us not the slightest clue to the manner in which this surpassing work was accomplished, whether by a process of slow evolution according to Divinely given laws, or by sudden saltations equally provided for in the Providence of the Infinite Maker, or by direct creation to a greater or more limited extent. Similarity in the design of the work of the Six Days proves an Omnipotent Designer, and renders only more hopeless the unproved assertions of evolutionary materialism.

Similarity in bodily structure between man and the purely animal world leaves untouched that essential difference, the rational human soul. There is a chasm here which no theory of evolution can bridge. Apart from all religion, the science of psychology teaches us to reflect upon our own spiritual activities and so to attain to an understanding of man's rational soul, simple and spiritual. The brute cannot pass beyond sense perceptions; it can form no abstract thought. It is without reason, and therefore without language, without science, without religion. Ten million years cannot evolve these out of brute instinct. Man alone is capable of all these, and is able to 
conclude from his spiritual operations the existence of his own rational soul, as an immaterial, simple, spiritual principle, differing essentially from the merely sensitive life principle of the animal. Man is gifted with reason and free will, neither of which the brute possesses. It can but follow its animal instinct.

The origin of matter postulated a Divine creative act, so too did the origin of life, and the same is true beyond cavil of the human soul. Materialistic evolutionists are wilfully deceiving their followers, when they claim as a fact the evolution of the soul of man, by whatever name they may call it, from the unreasoning brute. Not merely can they not prove such an evolution to have taken place, but it remains in itself impossible. The only explanation possible is that, which under a rich oriental symbolism the Scripture offers when it tells us that into the last made of all His creatures God breathed the breath of life: And the Lord God . . . breathed into his face the breath of life, and man became a living soul.

This, in poetic words, expresses the fact of the creation of the human soul, a creation repeated in each instance. Such is the value of the soul of man, in which is found the image and likeness of God, and which is created to be united to Him eternally-unless, indeed, it would use the freedom of its will to make this union impossible forever. 
Here therefore is the third great chasm, the essential difference between man and the brute, which no efforts of materialistic evolution can ever bridge over. It is therefore satisfied with meeting all these insuperable difficulties by mere declamatory denunciations of "myths" and "superstitions." Yet Christianity offers the only sound and reasonable answer where materialistic evolution fails most hopelessly. Its vain denunciations are but an idle baying at the moon, which moves on serenely in her course, as the Church has done through all these centuries, claiming the love and admiration of the world's greatest minds.

But if the human soul is certainly not descended from the ape, can the same be said of the human body?

The first of the "Princeton Lectures," sent out to all the alumni of the university to keep them in touch with its intellectual life, was an essay on human evolution by the professor of biology, Edwin Grant Conklin. The opening words of the lecture are the professor's own statement of Christian doctrine. "The doctrine of special creation," he says, "taught that man was perfect when he issued from the hands of the Creator, but that his disobedience brought upon him imperfection, degeneracy and death." This, in his superior wisdom, he forthwith sets himself to contradict systematically by the following mixture of 
truth and fiction which ađmirably illustrates the materialistic dogmatism of the schools:

There is no longer any doubt among scientists that man is descended from the animals, that he is a vertebrate, a mam. mal, a primate.

Even non-scientific persons generally recognize this animal relationship. ... There is no longer any doubt among leading anthropologists and biologists that not only the body but also the mind and society of man are the products of evolution, and there is no reason to doubt that the great principles of evolution which have operated in the past will continue to act in the future. ${ }^{1}$

Now no one means to question man's similarity to the animal world, that he is a mammal and a vertebrate, but nothing could better show the need of a course of logic than the deduction that therefore man must have descended from the ape. There is no longer any doubt, he implies, nor any reason to doubt that such an evolution has actually taken place. In the light of all that has hitherto been said it is plain that there is no reason whatsoever to assert it, since there is not one vestige of a proof. This is not bad enough but the professor must continue by setting a date for the appearance of the first hairy progenitors of man, and asserts with infallible certainty the ape-man nature of the Pithecanthropus erectus. This, of course, is not science. It is, we repeat it, unmitigated dogmatism. Sufficient attention has already been given by us to this specimen of a sup-

1 "Has Human Evolution Come to an End?" 


\section{I70 EVOLUTION AND SOCIAL PROGRESS}

posed missing link, as also to the question of the Neanderthal man. Might their bones at last be allowed to rest in peace! But we shall again be obliged to return to this subject in our chapter on "The Antiquity of Man," where we must further consider the very typical statements made by Professor Conklin.

The evolution of the human soul is out of all question, scientifically as well as religiously. In regard to man's body the evidence of evolution could clearly not afford more, at the best, than a legitimate guess, on the supposition that there were no conflicting reason to destroy the foundation of even such a concession. Scientifically, while there are many similarities between man and the higher mammals, there are also great divergencies which make any certain conclusion impossible. ${ }^{2}$ "The radical difference," says O. Walkhoff, "goes so far that it is possible to determine analytically from any X-ray photograph of a frontal section, and even from any complete piece of bone, whether it belonged to a man or an ape; in other words, whether its owner walked upright or not." 3 Ranke in his celebrated work, "Der Mensch," has indicated the striking differences between man and beast in their structure. Many other anthropologists of note have insisted that

${ }^{2}$ The bodily difference between man and the apes are stated fully and clearly in J. Ranke's "Der Mensch" ( 2 vols.) and Bumüller's "Mensch oder Affe."

${ }^{3}$ See Wasmann, "Modern Biology," p. 445. 
there can be no place for man in the systematic succession of apes. Quatrefages, the great French scientist, in his work "'L'Espèce Humaine," translated into English under the title "The Human Species," says:

Now man and apes present a very striking contrast in respect to type. The organs, as I have already remarked, correspond almost exactly, term for term; but these organs are arranged after a very different plan. In man they are so arranged that he is essentially a walker; while in apes, they necessitate his being a climber, just as strongly ... a walking animal cannot be descended from a climbing one.... The researches of Walker on the sphenoidal angle of Virchow lead to the same conclusion; for in man the angle diminishes from the time of birth, while in the ape it is always increasing; so much so that sometimes it is effaced. ${ }^{4}$

Applying the principle of Darwin himself, he shows in regard to the temporal sphenoidal convolutions that the development of man is in inverse order to that of the ape, and that hence "Man cannot be considered as the descendant of any simian type whatever."

Kollman, Virchow and others have similarly pointed out the impossibility of man fitting in anywhere in a succession from the apes in view of the differences in the extremities of the limbs, which would rather make the ape a descendant of man. ${ }^{5}$ But the main difference in structure between man and all other animals, whether we

" "L'Espèce Humaine," p. ro7.

Virchow, Kollman, etc., long ago held that on evolutionary principles man and the apes would seem to be the two extremes of entirely divergent lines of development. 


\section{I72 EVOLUTION AND SOCIAL PROGRESS}

would consider him as a descendant or merely a kinsman of the ape, is that pointed out by Quatrefages, the upright walk of man. All bodily differences hinge upon the essential difference between man and brute, and that is the difference of rationality and irrationality. It is first expressed in the development of the cranium, which in man is far greater than in the ape, and thence may be traced throughout the entire bodily structure. The immense jaws, the huge teeth, and the length of arms tell of the purely animal nature of the orang-outang.

When now we study the different theories based upon comparative morphology we find on consulting Kohlbrugge's list that they are about as numerous as the leading writers upon this subject. Hence an imaginary common ancestor to both man and the ape was invented in the fictitious "Molchmaus."

The ape theory has been rejected by many of the most noted evolutionists. The argument of similarity, if it proved anything, would rather favor the school which holds that the ape is descended from man. Thus the human hand is more similar to that of the lower apes than to that of the highest anthropoid apes who in this respect would, on the evolutionary hypothesis, be considered as representing a far more advanced stage of evolution than man. This reverse view of evolution has, indeed, long ago been seriously ad. 
vanced and is defended today. Thus we were informed in a cable to the New York Times from London, February 28, I9I8, that according to the professor of anatomy in the University of London, "The missing link of Huxley, if ever found, would not be a more ape-like man but a more human ape." This news item, which was not in the least new to those acquainted with the history of evolutionary theories, was thus introduced by the press:

That man is not descended from anthropoid apes, that these would be in fact more accurately described as having been descended from man, that man as man is far more ancient than the whole anthropoid branch, and that compared with him the chimpanzee and orang-outang are new-comers on this planet, were assertions made by Professor Wood Jones, professor of anatomy in the University of London, in a lecture yesterday on the origin of man. The professor claimed these assertions were proved not only by recent anatomical research, but were deducible from the whole trend of geological and anthropological discovery.

This was not a new theory but had been propounded by von Buttel-Riepen ${ }^{6}$ following upon Klaatsch. There is exactly as much evidence to prove that the ape is descended from man as to prove that man is descended from the ape, and this evidence, we have seen, is zero. As the conflict of opinions shows, science has stressed for us that there are certain similarities of structure between man and the higher vertebrates, a fact

"Man and His Forerunners" 


\section{I74 EVOLUTION AND SOCIAL PROGRESS}

which was always clear to everyone. Beyond this it has given us nothing but matter for conjecture. Says Moritz Alsberg:

That man is directly descended from apes is inconceivable, and it is possible to speak of relationship existing between man and ape only in as far as both are ultimately connected at the root of their common geneological tree, and this applies to all mammals. ${ }^{7}$

But this common ancestor from whom both man and the ape are supposed to be descended along different lines, according to such an hypothesis, is equally imaginary, since there is absolutely no evidence of such a common origin that science can establish. There is not one connecting link between man and this supposed ancestor in all the known fossil forms. All attempts hitherto made to establish such a pedigree are the work of pure imagination but not of science. The wise statement of Ranke is no less true today than when first expressed, and without doubt will remain as true to the end of our researches:

Whilst a charming picture of the past and possibly of the future is being shown us, and whilst a fanciful design is being carried out in all directions, we are as a rule in quest of facts, not of theories. The facts, however, upon which Herr Klaatsch [or any other who would trace a hypothetical pedigree for man] claims to base his ingenious theory, do not at present exist, and I must protest against his assuming that they have been really furnished by zoology and paleontology any more than by anatomy.... All else is still a matter of hypothesis, and if anyone attempts to use it in order to produce a finished picture, the result is a work merely of the imagination.

"Cfr. Wasmann, "Modern Biology," p. 463.

${ }^{8}$ Lindau Anthropological Congress, 1899 . 
Long before the extinction of the Neanderthal type, men such as we are had existed in the lands now known as England, France and Italy. Such is the verdict even of Keith. ${ }^{9}$ The missing link belongs to fiction. $\mathrm{He}$ is missing. That is all.

"The Antiquity of Man." 


\section{LEADING ARGUMENTS FOR DESCENT}

W

E shall here consider a few last arguments that are still to be taken into account in showing the futility of the attempts to trace man back to a purely animal source. We are now all familiar with what is well described as the Haeckelian "hoax" that was successfully perpetrated upon the scientific world for a length of years. The embryonic growth of man was fancifully compared with the development of the human race. Every individual was thus said to pass through various stages representing a supposed faithful reproduction of the evolution of all his race, from a single primitive cell, the imaginary Moneron, through worm, fish and ape, with all the intermediate forms, on to Homo sapiens, or modern man. All this was delightfully ingenious, its only fault being that it was not true.

Haeckel at first postulated twenty-two and later thirty stages of development, by which he purposed to prove the descent of man from the beast, and so, as he thought and expressly stated, to de- 
stroy Christianity forever from the face of the earth. To this end he shamelessly falsified science and filled the gaps in man's ancestry with beings his own imagination had created and which he named, "primitive gastræadæ, primitive amniotes, primitive promammals, primitive marsupials," etc. For a time this deception succeeded to such an extent as to become a popular creed, an application to man of what is known as the biogenetic law.

It is no longer necessary to disprove Haeckel's biogenetic law, though this for a time was the gospel of supposed science in our schools and uni, versities and still continued to remain part of the gospel of Socialism, and, unfortunately, of a large number of sociologists. On this subject Menge says:

Professor Haeckel's theory that man passes through the same stages as did the race, that is, first becomes a fish, then goes on through the other forms, until he shows in his embryonic development every form through which his ancestors have passed, is a theory which Professor Kellogg well says is now only a skeleton on which to hang exceptions. It has also been since said by another biologist that there is a great want of logic in saying that because a human being passes through a similar stage as does the fish, that therefore the human must have been a fish once upon a time, when all that should be said is that the human and the fish pass through the same stage. ${ }^{1}$

The reason for honoring the human race by placing the fish among its early progenitors was the gill-like and fin-like appearance of a certain 1 "The Beginnings of Science," p. 148. 
feature of the human embryo, known as branchial clefts and arches. From this superficial likeness the inference was drawn that our ancestors were once fishes disporting themselves in the briny deep. The first and largest of the branchial arches in question later forms the oral cavity and the parts belonging to it. Just why this so-called "shark-fin" should evolve thus is a mystery we leave to Haeckel's followers to solve. The one branchial cleft that remains in man forms the external auditory passage. Quite correctly therefore Wasmann writes:

The pharyngeal arches and clefts in the human embryo bear a superficial likeness to the gills of fishes, and so they have been called branchial arches and clefts, whereas they are really indifferent pharyngeal extroversions in the embryo, supplying the material for other subsequent formations. Can any one seriously regard them as evidence that our forefathers were once fish, and that the embryonic development "recapitulates" this former fish stage ? ${ }^{2}$

The thoughtful reader, as the writer adds, cannot fail to see what a vast difference there is between fanciful interpretations and really scientific attempts to account for the various phenomena of nature. Materialistic evolution is purely a myth and a nightmare. "I remember once hearing a rather well-known professor of biology suggest," Dr. James J. Walsh remarks in America, "that the reason why little boys like to sit down and wiggle their toes in the mud along the beach, is

" "Modern Biology," p. 454. 
because this action represents an atavistic reversion to the time when they were crawling creatures and played in the mud."

The fact is that if anything were proved by the discredited biogenetic law it would be that the ape is rather descended from man, since among the higher apes the young far more closely resemble man in their cranial formation and their facial similarities than the old. Whence it would obviously follow, in conformity with the Haeckelian law, that since the apes too must then be retracing their race history they were formerly human beings, that are now evolved into apes. This argument would be all the more conclusive in as far as the cranial development of the human embryo at no stage resembles that of the ape. ${ }^{3}$ Surely there is room here for Puck's exclamation: "What fools these mortals be!" And yet over 300,000 copies of Haeckel's best known volume were sold in Germany before the World War, and in 1906 German rationalists united into an Haeckelian "Monist League," at Jena, the main object of which was the dechristianization of the scientific and public life of Germany. English and American universities had nothing better to do than to repeat their absurd and intolerant materialistic inconsequences.

Sociologists, on their part, while generally most positive when indulging in assertions based upon

'Ibid., 502. 
the grossest materialistic evolution, which they mistake for gospel truth, are according to Kellogg's own statement not seldom innocent of any real acquaintance with science. Hence their blind adherence to the recapitulation theory, as the hypothesis of the Haeckelian biogenetic principle is usually called. It is well worth quoting Vernon Kellogg's words on this subject. Coming from such a pronounced materialist they may possibly be appreciated the better. He says:

To my eyes, much biological sociology rests on two very insecure bases; (I) a too slight acquaintance with biology on the part of the biological sociologists, and, (2) an acceptance of, and confidence in, certain biological theories which are certainly unwarranted, and are not all shared by biologists themselves. Biological science contains much that is proved and certain; but also much that is nothing more than a working hypothesis, provisional theory and anticipatory generalization.

As the proved part is largely of facts of observation, isolated and unrelated, and the unproved part is composed of the large and sweeping generalizations, the plausible, provisional explanations, such as the various theories of heredity, of the results of struggle, of the development of mutual aid, etc., i.e., is exactly the sort of material that the sociologist needs to weave into his biological foundations for the sociological study of man, it is exactly this unproved part of biology that the searching sociologist carries home with him from his excursions into the biological field.

The recapitulation theory looms up large and familiar in biological sociology; it is mostly discredited in biology. The inheritance of acquired characters serves as a basis for much sociology; most biologists believe it is impossible. The selection theories are gospel to some socielogists; they are the principal moot points in present-day biology. And so on.

Biology is not as yet come to that stage in its development 
where it can offer many solidly founded generalizations on which either sciences can build. ${ }^{4}$

This certainly should help to teach restraint and caution to both scientist and sociologist. "The recapitulation theory," in fine, says Professor Kellogg "is mostly wrong; and what is right in it is mostly covered up by the wrong part, so that few biologists longer have any confidence in dis. covering the right." 5

So exit the "biogenetic principle" that made Haeckel famous, and the "recapitulation theory" which is its expression; though Socialists and not a few sociologists will still continue fondly to accept it, without qualm, as a fact beyond dispute.

Another argument for the descent of man from the ape is that taken from the resemblance of human blood to that of the higher apes. It is a fact that animals belonging to groups that are closely related in structure give certain blood reactions that help to identify the group; thus lizards and snakes give similar reactions, whereas turtles react more like the crocodiles, so that from this point of view, the turtle is said to be only remotely related to the snake or lizard. All ruminants (sheep, deer, oxen) will thus be found to be related by blood-tests; and what is more to the point, the man-like apes give certain reactions similar to those of man. Now what of this?

" "Darwinism Today," pp. 22, 23. 
In the first place, nothing new is really presented from an argumentative standpoint; we know already that there are striking resemblances in skeleton and bodily structure between apes and man, and if we now learn that there is similarity also in the fluids that circulate in their bodies, we are not surprised at all. It seems reasonable to expect it, granting a Divine design. But these chemical tests are not as infallible as is sometimes believed; Brumpt for instance found from his experiments with blood infected through sleepingsickness that certain reactions were presented by apes; but these same reactions were presented also by certain kinds of pigs! Raehlmann, moreover, found certain peculiarities in human blood that are not found in any other vertebrate. The conclusion of Prof. W. B. Scott is the only safe statement we can make. After mentioning that blood-tests would show a closer relationship, apparently, between parrots and ostriches than between wolves and hyenas, he says: "It is unsafe to found a scheme of classification upon a single character, for the result is almost invariably misleading. The results of blood-tests must be critically examined and checked by a comparison with the results obtained by other methods of investigation." 6

" "Theory of Evolution," p. 80. 
In the specific instance of man, Rössle shows that the test of blood reaction between man and the higher apes affords no proof whatsoever of a close evolutionary relationship. ${ }^{7}$

One reason, no doubt, why these blood-tests aroused some interest at first, is that the word "blood-relationship" in ordinary language implies common descent; in science, however, it merely means chemical similarity, such as may exist in the flesh, the nerve-substance, the bone, of animals of a very similar structural type.

Finally we approach the subject of the so-called rudimentary organs. To make the meaning of this term clear, consider the case of the whale, which has two front paddles corresponding to the forelegs of quadrupeds, but no external appendages reminding one of the hind legs; its body is in fact cylindrical. On examining the skeleton, however, we find in the Greenland whale that the hip-bone, the thigh-bone and the shin-bone are visibly present, though in a reduced, atrophied and useless condition. Here we have rudimentary organs that are permanent; temporary rudiments are likewise found in the embryos of certain whales, the embryo having at first a dense covering of hair and numerous teeth, which appendages are presently atrophied and lost. The teeth are thought to be probably of use in the growth of

"Cf. Wasmann, "The Problem of Evolution," pp. 67, 68. 


\section{I84 EVOLUTION AND SOCIAL PROGRESS}

the jaw. Many similar cases could be cited, which seem to furnish a very strong argument for the relationship of certain groups of animals, and for their probable descent from certain ancestral types. Concerning man, what evidence can be drawn from this line of thought as to his descent from the ape?

The answer is simple; none whatsoever! In the first place, many of the organs once thought to be vestiginl or rudimentary are now known to exercise very definite and important functions of which scientists had been ignorant before. Specific instances mentioned by Wasmann are: the thymus gland, now known to eliminate poisonous matter from the system, and the pineal gland, once actually taken to be the remnant of a third eye possessed by some brute progenitor, until Cyon made known its function as a regulator of the flow of blood at the base of the brain. So too in the case of the thyroid gland. ${ }^{8}$

A second explanation applicable in some instances is, that organs are apt to fall into disuse owing to changed conditions of living. Thus the ear and face muscles of man, now useless, may have been more developed at some early period, and have degenerated later. As regards the vermiform appendix, particularly referred to by Darwin and his earlier followers, its peculiar pathological character might easily be due to

${ }^{8}$ Cf. Ibid., pp. 65, 66. 
changes of diet, to hypercivilization in other words; yet there are many pathologists who believe that this organ serves some useful intestinal purpose, since it seems to close up only under morbid conditions. Prominent pathologists, in fact, believe that the appendix, with its abundant lymphatic tissue, serves a purpose for the intestines similar to that served by the tonsils for the palate. ${ }^{9}$

No solid or structural rudimentary organ in man can with certainty be pointed out. The slight extension of the spinal column, which in rare cases may serve the sensational magazine-writer as an instance of a "tailed human baby," is of no scientific weight, since the far more complex phenomenon of six perfect fingers on each hand not only occurs, but is apparently hereditary in certain circumstances; and these new bone-structures are assuredly not vestigial or rudimentary. In view of our present ignorance concerning the causes of such phenomena, the vestigial argument for the evolution of man is devoid of all logical value.

From all that we have seen it is plain that there can be no reason for dogmatizing upon the subject of evolution as applied to man. Yet in the volume of the Yale professors quoted in our first chapters, as in countless other university productions, we have man's descent from the ape detailed with minute preciseness, for, we are told: "Man's

${ }^{\circ}$ Cf. Ibid. 
nearest blood relatives, whatever may be his prejudice in the matter, are the so-called anthropoid or man-like apes: the orang, chimpanzee, gorilla, and gibbon, all descendants from the same stock which gave rise to humanity." 10 And again: "There is reason to believe that the human precursor, before leaving the sheltered life of an arboreal primate, progressed and acted much as do the gibbons, with a consequent quickening of the intellect as time went on." 11

We might quote ad infinitum similar passages of professorial wisdom, all written with the same assurance as that of the learned professors who pronounced upon the Talgai skull as one of the missing links belonging to the Pleistocene period. They knew with certainty that it was the skull of a youth between fourteen and sixteen years of age, "an individual in whom all trace of the brute had not yet disappeared." All indeed would have been well, except for some one prosaic enough to prove that the person in question had, with some other aborigines, been shot on the open plain near Talgai, in 1848 , and tenderly laid away by the police in a billabong filled with red basaltic clay.

$$
\begin{aligned}
& { }^{10} \text { Lull, "The Evolution of the Earth," p. I39. } \\
& { }^{11} \text { Ibid., p. r4r. }
\end{aligned}
$$




\section{THE CHURCH AND MAN'S ORIGIN}

THE position of the Church upon the subject of man's origin and antiquity will be

1 found eminently scientific by any one who approaches this theme without bias. University professors have been as certain of a hundred other things that have since been proved to be false as many of them are still obsessed with the idea of an infallible materialistic evolution, impossible as it has been shown to be both philosophically and scientifically. The master minds of science have been Christian, and in the departments of biology itself, the stronghold of evolution, all the great founders, with one exception, as we have shown, were positive believers and almost half of them Catholics. ${ }^{1}$ If brilliant minds like Mendel, Pasteur, Malpighi, Schwann and Müller found no difficulty in perfectly harmonizing their biology and their religion, without one jarring note of discord, lesser minds might well consider that the fault may possibly lie with them if they fail to see the actual agreement that cer-

${ }^{3}$ See Chapter III. 
tainly exists between all true scientific facts and the teachings of the Church. If the latter cannot possibly be brought into harmony with theories that lack all proof and probability, and which in many cases are philosophical absurdities, why blame Christianity?

To set aside, however, with finality, the old falsehood of a conflict between religion and science, which many still insist upon by their recommendation of such unhistorical and absolutely unreliable authors as Draper, White, or Haeckelthe latter in particular where he touches upon the subject of Christianity-it may be well to begin by quoting the following list, far from exhaustive, of some of the greatest modern scientists, who were all not merely Christians, but sons of that ancient Church which has come down to us from apostolic days:

Ampère, electrician, physicist, mathematician; Bedford, founder of University Medical College; Cassini, discoverer of four of Saturn's satellites; Cauchy, inventor of the "Calculus of Residues"; Cavalieri, originator of the "Method of Indivisibles"; Colombo, discoverer of pulmonary circulation; Divisch, first to erect the lightning-rod; Eustachius, one of the greatest anatomists; Fallopio, also immortal among anatomists; Fizeau, first to determine velocity of light; Foucault, demonstrator of earth's rotation by pendulum; Fraunhofer, the originator of spectrum analysis; Fresnel, famous for his inventions in optics; Galvani, whose name is identified with electricity; Grimaldi, forerunner of Newton and Huyghens; Gusmao, naturalist and first æronaut; Halloy, Belgian pioneer geologist; Haüy, father of modern crystallography; Lænnec, celebrated pioneer in medicine; Lamarck, zoologist and natural philosopher; Laplace, 
mathematician and astronomer; Lavoisier, father of modern chemistry; Magellan, first to circumnavigate the world; Malpighi, father of comparative physiology; Mendel, formulator of laws of heredity; Morgagni father of modern pathology; Müller, founder of modern physiology; O'Dwyer, inventor of intubation; Paracelsus, reformer of therapeutics; Pasteur, founder of physio-chemistry; Schwann, originator of the cell theory; Senfelder, inventor of lithography; Vernier, a name familiar in mathematics; Vesalius, who reorganized the study of anatomy; Vico, famous as an astronomer; Volta, whose name expresses an electrical unit. ${ }^{2}$

To come now to our subject, after this digression. The Church, in the first place, holds the doctrine of the direct creation of the soul of man. No one can claim, in the name of science, that any facts have ever been advanced to prove that the intellectual soul of man was evolved from the brute. Even were we to admit the existence of that "link" between brute and man, which has quite rightly been called "missing," there would be no evidence to show that after a certain stage of evolution had been reached God did not breathe into this brute, evolved from the primal matter $\mathrm{He}$ had created and gifted with the life $\mathrm{He}$ alone could have bestowed, an immortal soul. Such might certainly have been the course of nature, had God so willed it.

\section{Aside from all mention of Scripture and Reve-}

${ }^{2}$ The names of all these world-famous scientists are to be found in the "Catholic Encyclopedia," with a scientific exposition of their work. The "Catholic Encyclopedia" itself may be mentioned as perhaps the most convincing argument of the high grade of scholarship and scientific attainment within the Church. 
lation, reason, as we have seen, demands no less than these three creative acts: the creation of the primal matter, of the first life and of the intellectual soul of man. Briefly to repeat:

Experience and philosophy alike tell us that matter is contingent. It therefore requires a necessary cause that of its very nature is self-existent and non-contingent. This Being we call God. Science again tells us that life did not exist from the beginning in this material universe, and that it could not have been transported here from some distant planet, since this would but transfer the same difficulty to another sphere. Science further informs us that spontaneous generation cannot be admitted. Philosophy confirms the truth of this by showing the absurdity of supposing that life could arise from dead matter. Clearly there is need here, therefore, of the interference of an external agency. Again, the Agency that was necessary to create life, we call God. Finally, the intellect of man transcends all things purely sensitive and material. It differs essentially from the brute instinct. The brute is incapable of intelligent language because it is incapable of forming mental abstractions, because it is without the faculty of reason. To bridge this third chasm a creative act must of necessity be supposed, a necessity which no one, indeed, could question except under the influence of the preconceived prejudice of materialistic evolution. 
The Supreme Intelligent Being, who alone is able to create the personal, intelligent soul of man, we call God-not an impersonal, material, Monistic god, that is nothing more than the material universe itself, and therefore could not have called into being life or intellect, wanting all these itself from the beginning; but a personal, living, intelligent Creator. Since somewhere self-existence must be postulated of some intelligent being, or nothing could exist at all, we are forced by our reason to come to this one Supreme Being, necessarily self-existent by His very nature, and so above all mere finite and contingent matter, who alone was capable of calling into existence matter and force, life and soul.

But what of the body of man? Again the attitude of the Church is the only one that true science can countenance, when she holds it rash to assert as a fact an evolution of which no proofs exist. We have shown abundantly in the preceding chapters that there is no vestige of scientific evidence that can prove the descent of man's body from the brute, whether said to be derived directly from the ape or else from some ancestor common to both man and ape. The very fact of the endless controversies over these matters shows how far science is from having in any way demonstrated the brute origin of the human body. The idea of a unified design on the part of the Creator throughout His creation, such as we 
should naturally expect, fully explains every point of similarity without any necessary recourse to evolution.

It is unwarranted to mention the word "science" in this connection. There can be question only of guesses and surmises. All must admit that no decisive proof exists of the descent of man's body from any animal precursor. No one would even dream of making the supposition, were it not for the preconceived theories which it is believed must be defended at all costs. This is often done honestly, simply because men have almost from infancy been indoctrinated with these prepossessions, as they had once been taught to believe that the earth was flat, and any evidence to the contrary was laughed out of court. This attitude of mind can readily be understood, but it should not for one moment be confounded with science. There can be no question of science until the evolutionary bias has been completely set aside, its wild conclusions modified or rejected, and men can calmly use their judgment without any of that prejudice which still springs from a false training in a supposedly scientific creed. As the former Parkman professor of anatomy at Harvard, Dr. Thomas Dwight, so truly said of the conditions existing in the university world and outside of it, when he penned his lines, in I9I I : 
The tyranny of the Zeitgeist in the matter of evolution is overwhelming to a degree of which outsiders have no idea; not only does it influence-as I must admit that it does in my own case-our manners of thinking, but there is the oppression as in the days of the "terror." How very few of the leaders of science dare tell the truth concerning their own state of mind! How many feel themselves forced in public to do lipservice to a cult they do not believe in! As professor T. $\mathrm{H}$. Morgan intimates, it is only too true that many of these who would on no account be guilty of an act which they recognize to be dishonest, nevertheless speak and write habitually as if evolution were an absolute certainty as well established as the law of gravitation. ${ }^{3}$

But while this cringing to public opinion, and this fear of being considered reactionary and being overlooked, in consequence, for speaking . the truth plainly to a generation that does not wish to hear it, is as natural as it is greatly to be deplored, yet as Dr. Dwight adds: "That there is a large body of honest workers is a fact to glory in." The attitude of the Church is such a fact in which Catholics have every right to glory. For not merely is evolution in the case of man's body not proved, as she declares; not merely does the harmony of design in God's plan fully explain that similarity, which we should consistently expect to exist; but evolution, as applied to man, is unscientific and contrary to the facts of nature and the laws of evolution itself. As the same writer, whose authority no one will question in this matter, lucidly says:

${ }^{3}$ Dr. Thomas Dwight, "Thoughts of a Catholic Anatomist," pp. 20, 21 . 


\section{I94 EVOLUTION AND SOCIAL PROGRESS}

"Let us look at man anatomically. There is the very large cranium in proportion to the face, which we find far exceeds that of the higher apes; yet by no means so strikingly, some of the smaller monkeys. When we examine the relative weight of the brain to that of the body we find that in some of these monkeys it is even greater than that of man. Not very strong of arm, not very swift of foot, without a well-developed hairy hide, or large teeth, or strong claws, he seems as a mere animal an exceedingly unfortunate one, good neither for attack nor defense, in short very unfit for the struggle for existence, in that very imaginary period of half-fledgedness between brute and man.

"His instincts and his senses, that of touch perhaps excepted, though in the savage state undoubtedly greater than those of civilized man, are by no means remarkable. Take him as a mere animal, what is he but an egregious failure? By what kind of evolution could such a creature rise who shows throughout his body only instances of the survival of the unfittest?

"Let us try to imagine him rising in the scale according to the dogmas of evolution. Let us watch the arboreal monkey well fitted for his surroundings gradually losing all that fits him for them. We see his coat growing thinner, his arms shorter so that he loses his "reach," his legs longer so that climbing becomes harder, and at 
the same time his brain growing in some incomprehensible way, and for no good reason, except that it is necessary for the theory to believe that the brain-development went on so swimmingly that it compensated for the physical degeneration." 4

This is surely no exaggerated picture, and it shows conclusively the unreasonableness of insisting upon the bodily evolution of man from the brute. We are quite well aware of the droughts and cataclysms that are invented to show how the monkey was forced out of the woods and made to walk like man, but what are all these but mere dreams which fancy spins that the theory of evolution, as applied to man, may not appear too absurd when confronted with the common-sense facts. But if, on the one hand, the laws of gradual evolution and natural selection render the application of evolution to man's body unscientific, the De Vriesian theory of sudden mutations is equally unsatisfactory. Had man suddenly appeared, begotten as a monstrosity in the primeval forest, it is not difficult to tell the fate which must inevitably have overtaken him. If we are to suppose that an intelligent soul was at once infused into him by the Creator-a supposition which alone could save this theory-we might surely then far more becomingly accept the immediate formation of the body of man, directly

'Ibid., pp. $158,159$. 
by God out of the dust of the earth, before, in the beautiful Scriptural figure, He breathed into it an immortal soul, made to His own image and likeness.

The Rev. Walter Drum, S.J., professor of Scripture at Woodstock College, thus briefly describes the Church's position on this entire subject:

True, the Church has not defined that God formed Adam out of the soil as a material. But she has defined again and again that the soul of man is created. And the Vatican Council (Session iii, 24 April, 1870 ), repeated the definition of the Fourth Lateran (Chapter x, On Catholic Faith, against the Albigenses, A. D. 1215 ): "By His omnipotent power, at the very beginning of time, $\mathrm{He}$ made out of nothing both handiworks, the spiritual and the corporeal-that is the angelic and the mundane; and thereafter the human, as composed alike of spirit and body."

Here the Biblical Commission comes to our assistance. It has decided that the first three chapter of Genesis are historical; and that one may not call into question the historical worth of the literal meaning of those facts, herein related, which have to do with the very foundations of the Christian religion. One of these facts, which Catholics may not discard as figurative or otherwise lacking of historical worth, is "the peculiar creation of man" (Decree of 30 June, 1909). What is this "peculiar creation of man"? It is the formation of man in the manner of the Mosaic fact narrative. The body was formed out of dust. The soul was created out of nothing; and, by divine omnipotence, vivified the previously formed body. ${ }^{5}$

The thorough consistency of the Church's attitude with that of true science has been made sufficiently obvious. But what, it is occasionally asked, would the Church do if a "missing link" were ac-

'The Queen's Work, May, 1919, p. 132. 
tually found; if it were shown that man must have been made mediately and not directly by God from the dust of the earth, as some have sought to explain the Scripture passage?

There is no need for this supposition. But we may briefly state that under no circumstances will the Church ever refuse to accept a scientific fact; never will she show even the slightest hesitation not merely to accept but heartily to welcome it. But there must be question of certain facts, and not of idle theories, found necessary to give consistency to still other theories that in turn are capable of no verification. This has been stated often enough in these pages. Never will the words of Leo XIII be retracted: "We declare that every wise thought and every useful discovery, wherever it may come from, should be gladly and gratefully welcomed." ${ }^{6}$ In other words, a fact of science, no matter by whom it may be first made known, will always be welcomed by her as "a useful discovery," since it adds one more truth to our very limited store of knowledge, as distinct from theories and hypotheses with which the world abounds, and so enables us to understand God's works the better. No one need be concerned about the "missing link." For the rest we may repeat also the words of Pope Pius X, already quoted here: "Religion has no fear of science. Christianity does not tremble before dis${ }^{3}$ See Chapter VIII. 
cussion, but before ignorance." This is nowhere more true than in the question of materialistic evolution. Find the facts; give us the facts-all the facts! The Church will welcome them. But be honest in their interpretation and do not stress a point to save a theory.

It is with pleasure that we call attention here to the notable passages which the writer just quoted has gathered to show how basic in the Scriptures is the revealed truth of the formation of the human race out of the dust of the earth, as a pre-existing material. The very name Adam, "man," is in the first place cognate with the Hebrew word for soil, Adamah. And here then are some of the most important texts:

Genesis iii : 19- "In the sweat of thy face shalt thou eat bread, till thou return to the earth, out of which thou wast taken. For dust thou art; and unto dust thou shalt return."

Job x:9-"Remember that thou hast made me as clay; and thou wilt bring me unto dust again."

Jeremias xviii :6- "Cannot I do with thee, as this potter? Lo, as clay is in the hand of the potter, so art thou in my hand, O house of Israel."

Isaias xlv:9-"Woe to thee, that settest thyself against thy Maker, thou shred of an earthen pot. Will the clay say to the potter: What art thou making, or Thy work is without hands?"

Isaias xxix:I6- "Out on your perverseness! Shall the Potter be deemed to be the clay? Shall 
the thing made say of $\mathrm{Him}$ that made it, $\mathrm{He}$ made me not? Shall the thing formed say of Him that formed it, He had no sense?"

Psalm cii:I4- "He knoweth how we are formed; $\mathrm{He}$ is mindful that we are dust."

Wisdom xv:7-"The potter moulds soft clay, and toilfully makes for us every kind of vessel; of one and the same sort of clay, he moulds vessels for cleanly purposes and those for quite the contrary purposes. And what is to be the use of every vessel, the potter judges. Yea, in wicked toil he moulds a vain god from the same clay; he who but a little before was made of earth, and after a little while will go unto the earth from which he was taken ... He was ignorant of Him that moulded him; yea, of Him that inspired into him an active soul, and breathed into him a living spirit."

Romans ix:20-"Oh, man, who in the world art thou that art answering God back? Does the thing made say to its maker, Why hast thou made me so? Has not the potter power over the clay, so that of the same lump he may make one jar for noble, another for common use?"

Yea, man, who art thou that wouldst rise against the Potter who made thee? "Woe to thee, that settest thyself against thy Maker, thou shred of an earthen pot!"

And what, we ask in the next place, is to prevent us from taking literally the beautiful Scrip- 
ture narrative of the Creation of Eve, so perfectly consistent with the power and love of God, so profoundly significant of the affection of husband and wife, so strongly insistent upon the right of woman as of man, so clearly expressive of the inseparable nature of that marriage bond, with but one single standard of equal and mutual fidelity until death shall them part? Nearest from the heart of Adam came that human substance which the power of God was to build into the body of the first Eve; nearest to the heart of Adam was she to remain, husband and wife cleaving together, as one flesh. Sacred must woman be to man, but made doubly sacred in that new and greater Eve, who was to repair the fall of Adam by giving to us Christ, born of the Virgin Mary.

Yet for Adam there was not found a helper like unto him. So Jahweh God caused deep sleep to come upon Adam; and he slept. And He took one of his ribs, and closed in the flesh in the stead thereof. And the rib which $\mathrm{He}$ had taken from Adam Jahweh God builded into a woman; and $\mathrm{He}$ brought her to Adam. Then Adam said: She is now bone of my bones, and flesh of my flesh. She shall be called woman, for out of man has she been taken. On this account shall man leave his father and his mother and cleave to his wife; and they shall be as one flesh. ${ }^{7}$

Here then is a Genesis worthy of man and woman. There is nothing in science to contradict, and everything in fact and reason to confirm this simple, primitive account. How exquisitely

${ }^{7}$ Gen., II :20-24. 


\section{THE CHURCH AND MAN'S ORIGIN 2OI}

in accord it is with the position that man and woman occupy! To conclude with another Scripture version from the scholar last quoted, we can best picture for ourselves the first man standing lordly in the midst of God's creation, as we repeat the Psalmist's noble words:

And yet Thou hast made him little less than the angels; With glory and honor Thou crownest him,

And yet Thou hast made him to rule o'er Thy handiwork;

All things hast Thou set under his feet:

Sheep and oxen, all of them,

Yes, and the beasts of the wild,

The fowl of the air, and the fish of the sea,

That which passes the paths of the sea.

${ }^{8}$ Psalm VIII:6-9. 
IIR BERTRAM WINDLE felicitously refers to the huge drafts for millions on mil$S$ lions of years made on the bank of time by many of our modern scientists. Hundreds of thousands of years are lavishly disposed of by materialistic evolutionists merely to account for the supposed development of present-day man, Homo sapiens as he is scientifically called, from his very nearest zoological ancestor. "Through unnumbered millions of years," says Professor Conklin in the first of the Princeton Lectures to which we have already alluded, "evolution has moved on from the lowest form of life to the highest, from amœba to man."

There is no twitching of a muscle, no lifting of an eye-brow, no shrugging of a shoulder blade, as this assertion is made. Yet short of a private revelation there is no way in which the Professor could have obtained his certainty in this matter. Darwin denied that when there is question of species in the strict sense of the word an evolution from one to the other could ever be proved in 
even a single instance. ${ }^{1}$ Delange, as we have sufficiently shown, makes the same admission. ${ }^{2}$ Kellogg says as much. ${ }^{3}$ The same testimony is given by Quatrefages, Virchow, Wiegand, Müller, $\mathrm{Du}$ Bois-Reymond and many others. ${ }^{4}$ Indeed there is nothing else for any scientist to say. In place of an endless chain of connected species, we have loose rings, as it were, isolated species, with all the links between them "missing." It was this very impossibility of proving the transition from any one species to another that helped to popularize the saltatory theory, which calls for no missing links, but lets the species appear suddenly, fully formed, as we actually find them in our geological and paleontological researches. But here again there can be no certainty except upon the assumption of a private revelation.

Now the Church has always been exceedingly guarded in the matter of private revelations, and indeed of all revelations made since the days of the Apostles. In no case and under no circumstances does she ever demand an act of faith in them. Even the Catholic Faith itself, we repeat here, is never to be accepted by anyone until that person has been fully convinced by reasons of credibility such as intellectually make its acceptance imperative. If therefore the Princeton fac.

${ }^{1}$ See Chapter III of this volume.

${ }^{2}$ Chapter I.

${ }^{3}$ Chapter III.

'See America, Feb. 28, 1914, p. 487. 
ulty, or such portion as was responsible for this circular, is willing to have its alumni take science upon faith, Catholics will still continue to take it upon proof alone.

Even the private revelation, however, on which alone anyone could state that: "Evo'ution has moved on from the lowest form of life to the highest, from amœba to man," by a purely materialistic process, would demand a faith not merely without reason, but even against reason. We have seen clearly enough that by no unaided natural process can life evolve from dead matter, or intelligence from mere animal instinct. But this is not all the Princeton circular asks the alumni to take on faith. The document in question, which we quote because it is so very typical of modern non-Christian university methods, and not because it stands as an isolated example, continues:

About half a million years ago the immediate progenitors of man appeared on the earth. The earliest man-like fossil so far discovered is the Ape-man, Pithecanthropus erectus, of Java. About 100,000 years ago the Neanderthal man appeared, a member of the genus Homo but an extinct species, neanderthalensis. Then came, about 25,000 years ago, certain races of the existing species, Homo sapiens, such as the Cro-Magnon and the Grimaldi races. ${ }^{5}$

It would be difficult to group together more gratuitous statements than are to be found here, each cathedratically pronounced with an air of assurance that implies absolute and unquestioned

${ }^{5}$ Princeton Lectures, Number One, Professor E. G. Conklin. 
certainty. What is to be thought of the Pithecanthropus erectus, or "walking ape-man," we have sufficiently shown in our chapter on "The Missing Link." "The endlessly conflicting views pronounced on the upper portion of a skull, two molar teeth and a thigh bone, found at different times and in different locations in a Java river bed, out of which fragments this specimen is reconstructed, should give any scientist pause, since there is not a single detail in regard to these dubious relics on which his confreres can agree with each other.

Again we are told with absolute assurance that Neanderthal man belonged to an extinct species that appeared about 100,000 years ago, 75,000 years before the existing species. To show how unfounded this assurance is we need but refer to the conclusion arrived at in this matter by Professor Arthur Keith, whose authority the Princeton professor at all events will not question and who assumes the descent of man from some simian form. "We were compelled to admit," says Keith as the result of extensive investigations, "that men of modern type had been in existence long before the Neanderthal type." 7 So too Professor Dwight, who for some twenty-five years had been Parkman professor of anatomy at Harvard, concluded in anticipation of Keith's judg.

${ }^{3}$ Chapter XIII.

" "The Antiquity of Man." (Igr6.) 
ment: "For my part I believed the Neanderthal man to be a specimen of a race, not arrested in its upward climb, but thrown down from a higher position," 8 though he could not then point to the evidence. Even Osborn, with his fatal prepossessions, must admit that the Neanderthal skull marks a degeneration, which he expresses in his evolutionary way by saying: "We may suppose that the Piltdown type became gradually modified into the Neanderthal type by a series of changes similar to those passed through by the early apes as they evolved into typical modern apes, with their low brows and prominent ridges. This would tend to support the theory that the Neanderthal men were degenerate off shoots of the Tertiary race." 9

We are not concerned with Mr. Osborn's theories, but what interests us is the fact that he feels compelled to strain even his views to admit that a more perfect race had already preceded the $\mathrm{Ne}$ anderthal type. And here is what that eminent geologist, G. Frederick Wright, has to say, which we have every reason to believe will remain the final word:

Upon extending inquiries, it was found that the Neanderthal type of skull is one which still has representatives in all nations; so that it is safe to infer that the individual was a representative of all the individuals living in his time. The skull of Bruce, the celebrated Scotch hero, was a close repro-

" "Thoughts of a Catholic Anatomist," p. I70.

'H. F. Osborn, "Men of the Old Stone Age," pp. r4r, r42. 
duction of the Neanderthal type; while according to Quatrefages, ${ }^{10}$ the skull of the Bishop of Toul in the fourth century "even exaggerated some of the most striking features of the Neanderthal cranium. The forehead is still more receding, the vault more depressed, and the head so long that the cephalic index is 69.4I." 11

Macnamara, as we saw, found the average cranial capacity of a considerable number of Australian and Tasmanian skulls under his observation to be less than that of the Neanderthal man, while Klaatsch and other equally representative authorities recognized in the Neanderthal skull all the characteristics that can commonly enough be met with among the Australian negro in our day. ${ }^{12}$

Unfounded therefore as is the assurance of the Princeton lecturer upon the subject of the missing link, his authority in the matter of dates must evidently be discounted in the very same manner. This, the above argument already makes plain. There is certainly an immense difference between Professor Conklin's statements and those set forth in 1875 by James C. Southall, in his massive work on "The Recent Origin of Man." While later discoveries have added to our knowledge, it still is true that Southall's conclusions are far more scientific than the thousands of as-

${ }^{10}$ Quatrefages, "Human Species," p. 3 Io.

"Wright, "Man and the Glacial Period," p. 276. (Appleton, 1896.)

${ }^{12}$ Chapter XIII. 
sumptions to be found in treatises written with an evolutionary bias in regard to the origin of man. Such an attitude of mind necessarily makes independent judgment and sane originality impossible. Southall's contention that 6,000 or 8,000 years suffice for the antiquity of man will hardly be scientifically defended today, although this in itself does not of course prove it to be false. Yet the slightly larger time limit, which in conclusion he here allows, can be well supported. He says :

If, as I contend, primeval man commenced his career six or eight thousand years ago in a civilized condition in the temperate regions of the East, and there are no human traces behind these, the doctrine of evolution, so far as man is concerned, is at once negatived. Even if the man of Solutré, in Eastern France, the contemporary of the mammoth, and who, as I have attempted to show, occupied that station only a few thousand years ago, had apparently domesticated the horse, and in the words of $\mathbf{M}$. Pruner-Bey, est constitué homme dans toute la force du terme," ("was a true man in every sense of the word")-with regard to whom "rien dans son physique n'indique un rapprochement avec les Simiens," ("there is nothing in his physique to indicate a relationship with the ape").

Behind this hunter tribe, who have left their remains in the sepultures and refuse heaps of the palæolithic village, we find-nothing. In other words, Palæolithic Man in Western Europe-though not civilized, was an intelligent savage, like our Esquimaux or Red Indians; and neither archaelogy nor geology has detected any earlier human form. Such a man, civilized in Egypt, uncivilized but employing horses, making pottery, executing drawing [reference is here made to a beautiful reindeer picture by primitive man, serving as a frontis- 
piece to Southall's volume], in Europe, appeared abruptly on the scene a few thousand years ago-ten, if you choose. ${ }^{13}$

There have been many new discoveries since these lines were written, but they rather serve to confirm the ultimate conclusion, unless we presuppose materialistic evolution. That I0,000 years are actually sufficient to account for the whole history of man, from his first appearance to the present day, is a statement which can be supported by the best scientific evidence and the highest specialized scientific authority.

Endless cycles of centuries, as we have said, are of course required by materialistic evolutionists to account for the slow process of development from brute to man which this requires. Hence geologists, willing enough without further provocation to deal in large figures, were called upon to adapt themselves still more to the preconceived theories with which materialistic anthropologists insisted that science must be squared. Yet in spite of every attempt at conciliation vast discrepancies remained between the conclusions of these two classes. Science, in brief, has been cast to the winds to secure at all costs the verification of the utterly hopeless and entirely arbitrary theories of materialistic evolution.

In his article on Biblical chronology in the

13 "The Recent Origin of Man, as illustrated by Geology and the Modern Science of Prehistoric Archæology," Lippincot \& Co., 1875. Preface. 
"Catholic Encyclopedia" ${ }^{14}$ J. A. Howlett refers to Guibert's views upon this subject of the age of man: "Haeckel names more than 100,000 years; Burmeister supposed that Egypt was peopled more than 72,000 years ago; Draper attributes to European man more than 250,000 years; according to M. Joly, certain geologists accord to the human race 100,000 centuries; and G. de Mortillet shows that man's existence reaches to about 240,000 years." Yet after carefully studying all these views and the reasons or absence of reasons for such statements, Guibert himself comes to the conclusion that there is no evidence whatsoever that can compel us to go back farther than 10,000 years for the beginning of man. ${ }^{15}$

Among all the authorities that might here be cited there is perhaps none that deserves to be taken more seriously, where there is question of the age of man, than G. F. Wright, who devoted the greater part of half a century to the most careful and intelligent study of glacial conditions. It is by these in particular that the age of man can be most accurately determined.

Particular attention was given by him to what is perhaps the most perfect of all geological chronometers, the post-glacial Niagara gorge, whose geological conditions are most uniform, and whose erosions, therefore, enable us to draw the best-

${ }^{14}$ See Chronology (Biblical), section "Creation of Man."

${ }^{15}$ Guibert, "In the Beginning," p. 28. 
founded conclusions as to the first advent of man upon this planet. While geological clocks are usually the most unreliable of time-pieces, in so far as the conditions of today are often vastly different from those which existed at other periods, yet the uniformity of the Niagara rock makes possible such delightfully picturesque, yet scientifically reliable descriptions as the following chronological determinations:

With great confidence we can locate the position of the Falls at different past historical epochs. For example, at the time of the Crusades the cataract was about one-third of the way down to the head of the rapids. When the Falls had receded to the head of the rapids, Rome was being founded and Greece was just entering upon her classical career. When the Falls were at the whirlpool, Israel was just entering Egypt, while the beginning of the Falls at Queenstown occurred only a short time before the building of the great pyramids, and the expedition of Sargon from Babylonia to the shores of the Mediterranean about 3,800 B.C. ${ }^{16}$

On this and much other reliable evidence he bases his conclusion-certainly not infallible, but as safe as any that science has to offer-that the entire glacial epoch, whose period will most help us to ascertain the age of man, did not exceed 80,000 years, while the portion of this epoch during which man existed, he concluded:

"Cannot be less than 10,000, it need not be more than I 5,000 years; 8,000 years of historic ${ }^{10}$ G. F. Wright, "The Origin and Antiquity of Man" (1912). 
time is ample to account for all known facts relating to this development." 17

So too that expert geologist Prestwich limits the entire Glacial Period to only 25,000 years. ${ }^{18}$ The evidence of science, therefore, does not compel us to go beyond Io,000 years in calculating the entire period of man's existence upon earth. Similar conclusions were those drawn at a comparatively early period by Dr. Andrews in regard to the age of man in America from his study of the raised beaches of Lake Michigan. To these deductions J. W. Dawson, former Principal of McGill University, Montreal, thus referred:

The deliberate and careful observations of Dr. Andrews on the raised beaches of Lake Michigan-observations of a much more precise character than any which, in so far as I know, have been made of such deposits in Europe-enable him to calculate the time which has elapsed since North America rose out of the waters of the Glacial Period as between 5,500 and 7,500 years. This fixes at least the possible duration of the human period in North America, though I believe there are other lines of evidence which would reduce the residence of man in America to a much shorter time. ${ }^{10}$

To show on the other hand the absurdity to which such contentions as those of Professor Penck must lead when he extends the possible length of the Glacial Period to over 500,000 years, leaving from 250,000 to 500,000 years for the antiquity of man in Europe, Sir Bertram Win-

${ }^{17}$ See Windle "Church and Science," pp. 266, ff.

${ }^{18}$ Ibid., p. 269 .

10 "Story of the Earth and of Man," pp. 295, 296. 
dle, stretching his estimates beyond all need in order to satisfy all critics, quite appositely argues :

It is less than 10,000 years-to follow the generous estimate which we are using-since the knowledge of metal came into existence; less than 4,000 since iron became known. Some 6,000 or 8,000 years for the evolution of our present complicated civilization, and what of the previous 190,000 odd years? What was the highly capable Mousterian man doing, still more what were the undoubtedly talented Aurignacians and Solutreans doing, that they made so little progress in so vast an extent of time? ${ }^{20}$

Admitting the existence of backward nations today, the reason for which shall be given later, the history of Europe fits in badly, as the author says, with these long vistas of time. The vast discrepancies between the various geological computations of the Glacial Period, running from 500,000 years or more, to 25 ,000 years or less, show how absurd it is to speak of scientific certainty in this matter, or to be disturbed by "scientific" dogmatism. Professor Driver in his "Genesis," and the renowned "anthropologist, Abbé Breuil rest satisfied with an estimate of 20,000 years for the antiquity of man, but the various eminent authorities we have already quoted, and among them G. F. Wright, the most worthy of all, require no more than I0,000 years. We therefore remain scientifically near this figure, unless a greater period of years should actually be proved, which now is not the case. A close ${ }^{20}$ Op. cit., p. 268. 
approximation to this estimate apparently best accords with history and with actually discovered relics of man, and well accords with Holy Scripture.

No set number of years can be ascertained from the Bible. All that science can with any certainty tell us in the question of man's antiquity is, therefore, once more in full harmony with the account of the Inspired Book. The 5,I99 years before Christ, laid down in the Martyrology for the creation of Adam, is not to be taken as in any way defining the Scripture chronology. "The uncertainty which surrounds its chronology," says J. A. Howlett, "in no way detracts from the trustworthiness of the Bible as an historical document, or from its authority as an inspired record. The further back we go, the more general and in outline are our ideas of history; and so in Genesis the whole history of the world to the Flood is contained in a few brief chapters. As it is with the narrative of the events so it is with the chronology." 21

The chronological differences in the various Scripture versions are sufficiently well known. It is very clear, as Hugh Pope, O.P., points out, that there is no question here of mere idiosyncrasies of translators or copyists, but of a systematic procedure. The clue to this has been lost. Whatever chronology was given in this portion of Gene${ }^{21}$ Loc. cit.s, p. 738 . 
sis may have been intended mainly, he suggests, as a guide to the memory. ${ }^{22}$ At all events it served its original purpose. "For this period," says Vigouroux, "the chronology of the Bible is quite uncertain." 23 It is an uncertainty which in no way conflicts with the supreme end of saving our immortal souls. The chronological system of the Scripture, it must be remembered, is in no sense intended as a scientific study, and there is full freedom for scientific investigation on our part. But when the latest Sunday supplement announces the finding of a new "missing link," or some university professor discovers an implement used by Eolithic man-whose alibi has not yet been disproved-dated back millions of years ago, let the reader knowingly smile. Perhaps it may date back a thousand years, perhaps a few thousand even, perhaps it may have been consigned to the earth hardly one generation ago or two, like the once famous Talgai skull, whose incalculably remote antiquity was vouched for beyond cavil by its complete mineralization, yet which, as we elsewhere show, was found to have been scarcely older than the skull of poor Yorik when it drew from Hamlet those fond recollections and all that wise philosophizing upon mortal things:

22 "Catholic Student's 'Aids' to the Bible," pp. I9, 2 I.

${ }_{23}$ "Dist. de la Bible," 273. 


\section{I6 EVOLUTION AND SOCIAL PROGRESS}

Here hung those lips that I have kissed I know not how oft. Where be your gibes now? your gambols? your songs? your flashes of merriment, that were wont to set the table on a roar? Not one now to mock your own grinning? quite chap-fallen? Now get you to my lady's chamber, and tell her, let her paint an inch thick, to this favour she must come; make her laugh at that. 


\section{OUR FIRST PARENTS}

HE first man was not a savage. This is scientifically clear from all the evidence 1 we have already given. Only the preconceptions of materialistic evolutionary theories could ever have led to a contrary conclusion. The argument of history is as plainly against it as the words of the Sacred Scripture. The most that evolutionists might claim is ignorance of the real origin of man. In which case they would have the Scripture account to accept-or nothing.

Yet in saying that primitive man was certainly not a savage, which we shall still more fully substantiate, we do not by any means wish to imply in his case even the beginning of an advanced stage of material civilization. The helplessness of the first human pair after their fall could not be better expressed than in the Scripture statement that a Divine intervention was needed mercifully to furnish them even with their necessary and befitting garments. They were going out to face the inclemencies of an earth that was to bring forth thorns and thistles, that was to 


\section{I 8 EVOLUTION AND SOCIAL PROGRESS}

abound for them in hardships and sufferings, and that, after much labor, might at times yield but a scanty sustenance. The first fall from grace implied the loss of many privileges, although there was given even then the hope in the Redeemer, and the possibility of turning all human sufferings into sources of merit, so that in time to come the Church might sing: "Oh, happy fault of Adam, which has given us a Saviour!" All this may be unintelligible to the materialistic evolutionist, and we are sorry for him, but not a line of this account fails to stand in full conformity with the scientific evidence that either he or we can claim to possess.

That Adam may, for a time at all events, have probably lived the life of a cave man is not startling. It is the only thing we might expect. Clothed in the garments of skin, with the sentence of God upon them, the first man and woman now of necessity felt the consequence of sin. Whither could they turn, except to some hospitable cave which might afford them shelter from the storm that shook the ancient oaks above them, or from the cold dews and the chill frosts of night.

Had Adam been gifted with all the genius of a Newton and a Shakespeare combined-and it is not in the least impossible that such was the case-yet the vast possibilities of bronze and iron would still have been hidden from him except for a Divine revelation. In calling attention to 
the use of iron only at a far later date, the Scripture is in perfect accord with science, or rather we should express it in the reverse way, for while scientific facts can stand by themselves unchallenged, scientific theories can have no better commendation of their plausibility than their accordance with the Inspired Word.

A stone implement is all that Adam could naturally have fashioned, and this only with the greatest difficulty and probably in the very crudest way. He was serving his sentence, and we do not therefore presume that any very extraordinary assistance was given him, such as would have been accorded in Paradise, though we cannot, of course, say what knowledge he may have brought with him from there. It is true that even in exile his mind and heart may have been in the closest communion with his Creator, and his thoughts may have penetrated deeper and reached farther than our own. Yet the making of a bronze spear-head would still have been entirely beyond the wildest flights of his imagination, as the possibility of a gleaming steel needle would have remained undreamed of by Eve as she tried a hundred devices to fashion a garment of untanned skins.

Above all we must understand that no need was then felt of things that now seem to us so indispensable. The loftier the mind, in fact, of our first progenitors, the less they were probably, 
concerned with providing for more than the merest needs and simple comforts of the body. Yet the attainment of even this much often taxed their utmost ingenuity.

What was it, in fine, that the fall implied? "The break-up of human beatitude," Father Joseph Rickaby, S.J., answers, "the loss for Adam and his posterity of sanctifying grace and consequently of the entry into heaven and of the Vision of God; the loss of immunity from concupiscence, from sickness and from death; the loss of a high knowledge of the things of God, of familiarity with God, 'walking in Paradise at the evening air,' seemingly in human form; a loss of the ready obedience hitherto paid to man by the lower animals; loss of that ready subsistence from the fruits of the earth ever coming to hand without toil." Coming then to describe, in fewest words, the consequences that actually followed, the same writer thus traces the course of history, in full conformity with all that we know through both scientific and documentary sources:

The losses were all of privileges supernatural, not due to human nature as such. Man's nature was left entire. But it was left entire much in the way that a man, stripped of his clothes, and suddenly turned out of a warm room into the street, may be said still to have his entire nature. Human nature, after the Fall, was left at a great disadvantage, moral and physical. Man found himself in a novel situation for which he was not destined and was quite unprepared. Morally he had to struggle with the passions of his own nature, prone to evil, physically he had to wrest a livelihood from external 
nature, and defend himself from manifold dangers of death. In both struggles Adam's posterity was overborne. [This does not imply a want of the necessary Divine assistance for each individual soul, in whatever stage of civilization, to save itself, if so it wished. They were overborne, but through their own fault.] They sinned as their first parents had sinned, and the wickednesses of men were multiplied upon the earth. ${ }^{1}$ Much of this wickedness was probably merely "natural," and excusable on the ground of ignorance; not a little was "formal" and culpable. St. Paul speaks with horror of the condition of the pre-Christian world. ${ }^{2}$ Physically, as Adam's children multiplied upon the earth, the overplus of the population was thrust out into the ruder and less favored climates, food was hard to get, savage animals were many, and, naturally enough, man became savage as well as his surroundings. ${ }^{3}$

Here then is a picture that accounts, scientifically no less than religiously, for the facts that paleontology, archeology and history teach us.

Pastoral and agricultural occupations, as economists state and history exemplifies, would in the course of time engage the first attention of primitive man. Obviously it could not have been long before Adam and Eve would have attempted these forms of more permanently providing for themselves and their offspring, perhaps after their first severe struggles with nature. Their power over the animal world which they had once possessed, and the Divine injunction, even in "the paradise of pleasure," to busy themselves enjoyably in it, "to dress it, and to keep it," nat-

1 Gen., vi :5.

${ }^{3}$ Rom., I, ii, iii. Eph., ii.

"The Spiritual Exercises of St. Ignatius." 
urally would have suggested to them this course. But Adam was now to earn his bread in the sweat of his brow, as Eve was to feel the sorrow as well as the joy of giving birth. The fact is that we are soon definitely informed of the practice of both pastoral and agricultural pursuits, for we are told: "Abel was a shepherd, and Cain a husbandman." Once more, therefore, the Scripture recalls to mind Ampère's exclamation when we see our most advanced economic knowledge so perfectly verified in its pages.

Of Cain we are told that "he built a city, and called the name thereof by the name of his son Enoch." But of what kind this city was Scripture does not enlighten us. The most primitive concept of a rudely constructed shelter probably sufficed for these early builders. The erection of a roofed habitation would naturally enough have suggested itself even to Adam. A few poles and twigs, with mud for plaster, may have been sufficient for Cain's own palace. There were no Greek architraves or Gothic arches with sculptured figures. In vain would the archeologist now search for it, when even the mighty walls of Babylon are crumbled to the dust. And yet it is with a true civilization, and not with savagery or barbarism that we are dealing here. To gauge civilization, as has been the custom, by the implements that men used, and so to grade it in an ascending scale into the stone age, the newer stone 
age, the bronze age and the iron age, is entirely arbitrary. Moreover all these ages have existed simultaneously in different parts of the earth down to recent times.

Here precisely is the confusion that exists in the minds of our modern scientists. They cannot dissociate the two ideas of purely material comforts, which may be combined with real savagery at heart, and a high stage of all tinat really is of value in true civilized life. Whether dwelling in the modern cliff habitations, the sixteen- or sixtystory buildings of our huge cities, not seldom amid the most unnatural and often the most immoral conditions, cribbed and confined in small rooms and narrow streets, or whether meeting all the necessities of life in a more primal simplicity, "A man's a man for a' that." Even when wandering far from his earlier civilization and at times declining more and more to a level with his savage surroundings, we still find him covering the walls of the caverns to which he came for shelter, protection, or worship, with artistic etchings that excite our wonder. In the Cueva de la Vieja, belonging to the Old Stone Age, women are portrayed with long gowns descending from their bosoms. There are animated pictures of life, of the chase and war in this marvelous Alpera fresco, dating back to the so-called Reindeer period, formerly synonymous with "primitive savagery." 
On this subject the Duke of Argyll wrote long ago:

Implicity, if not explicitly, the savage theory, and the reasoning in support of it, assume that civilization consists mainly, if not exclusively, in a knowledge of the arts. Knowledge, for example, or ignorance of the use of metals, are characteristics on which great stress is laid. Now as regards this point, as Whately truly says, the narrative of Genesis distinctly states that this kind of knowledge did not belong to mankind from the first, but was the fruit of consequent discovery, through the ordinary agency of these mental gifts with which man at his creation was endowed. It is assumed in the savage-theory that the presence or absence of this knowledge stands in close and natural connection with the presence or absence of other and higher kinds of knowledge, of which an acquaintance with the metals is but a symbol and a type. Within certain limits this is true, and we may assume, therefore, that in Genesis also, the intimation given on this subject implies that so far as civilization means a command over the powers of nature, man was left to make his own way, through his powers of reason and through his instincts of research. ${ }^{4}$

Yet even in this earliest civilized society, of which the Scripture writes, we have already the signs of decline, which throughout the whole of history were to alternate with those of true progression, and thus account for every subsequent form of barbarism and savagery. There is evolution and devolution, at every stage. Here again the Scripture narrative wonderfully bears out the facts of history. The existence of savagery in every period, shortly after the Crea" "Primeval Man;" pp. 30, 3x. 
tion itself, and the evidence of it in the many relics that remain, is perfectly explained in the Sacred Record. The first man and woman transgressed the law of their Creator; the second man proved to be a murderer. With perfect correctness, therefore, does the writer just quoted argue that the causes of degradation were present at the beginning. They began with the first sin, and they continued in an accelerating ratio until the deluge, when we find them beginning anew with Cham. Hence the explanation for the prevalent idolatry that followed, and the wide-spread decline, moral intellectual and cultural. As Schlegel, quoted by Dean Harris, ${ }^{5}$ excellently says :

"When man had once fallen from virtue, no determinable limit could be assigned to his degradation, nor how far he might descend by degrees till he reached almost to the level of the brute. For, as in his origin he was a being essentially free, he was in consequence capable of change, and even in his organic, powers most. flexible.

"We must adopt this principle, as the only clue to guide us in our enquiries, from the African negro-who with his bodily strength and ability, with his docile, and in general, good character is far from occupying the lowest grade in the scale of humanity-down to the Patagonian, the almost imbecile Peshwerais, and the horrible cannibal of s "Earth's First Man." 
226 EVOLUTION AND SOCIAL PROGRESS

New Zealand, whose very portrait excites a shud. der in the beholder. So far from seeking with Rousseau and his disciples, for the true origin of mankind, and the foundations of his [false] social compact, in the conditions even of the best savages, we regard it, on the contrary, as a state of degeneracy and degradation." 6

" "Philosophy of History," I, p. 48. 


\section{PRIMITIVE MAN AND WOMAN}

HEY were paleolithic and neolithic men with whom we have so far been con1 cerned, and yet they may in many ways have been superior to the paganized civilization of our own days, where it has sunk back again into a barbarism of reckless divorce, animal dances and race-suicide. Only after the enumeration of generations, whose chronology affords us no definite knowledge that would enable us with any certainty to approximate the period of intervening years, do we finally come to the first mention of craftsmen in the modern sense: Jubal, the musician, and Tubalcain, "who was a hammerer and artificer in every work of brass and iron." 1 How rapidly this development had come about in this first center of civilization we are not able to say.

The great longevity of primitive man may be accounted for by conditions preceding the deluge, which itself is a thoroughly verified scientific fact, further substantiated by countless primitive traditions, which all confirm the unity of the human

${ }^{1}$ Gen., IV:23. 
race. That the earliest civilization is scientifically traced back to the very locality in which the Scripture places it is another rather remarkable fact for any one who may have been inclined to question the authenticity of the inspired Books. The common traditions of the nations, however perverted, going back to a state of original happiness, to the Fall, to the deluge, etc., are striking verifications of Scripture facts. The inspired writers may doubtless have availed themselves of the same primitive traditions, given at the source of the human race before the Flood, and again spread with the division of the tongues and tribes, from a single source after the Noachian deluge.

Radiating from the various centers of civilization, whether by adventure or accident at sea, whether fleeing from justice or seeking new homes, as the younger sons may often have gone forth with their wives to found new settlements, these early pioneers might readily lose touch completely with their former civilization and proceed farther and farther into the uninhabited plains or forest clearings that promised them a more ready subsistence or an escape from the dangers threatening them. Thus such refinements of civilization as had existed among them would quickly be lost, and the way through barbarism to savagery might soon be traced. Their elevation to a higher stage would then come, not so much through any efforts of their own, but through what anthropologically 
is known as "diffusion," the contact with strangers who bring with them a higher culture. So the Red Indians of America were lifted, without any intermediate stages, from the stone to the iron age. So the paleolithic man of today may enjoy the use of firearms tomorrow.

All this is confirmed by the fact that in every known period of history we find all the various stages of civilization, from culture down to barbarism, represented in various parts of the earth. Simultaneous with the paleolithic man, and what is more, with the real savage, whose traces we discover, there may have existed in other portions of our planet all the different stages which archeologists and anthropologists describe. Often stone implements will be found in the same period and the same locality with implements of bronze and iron. Abundant proofs of all this could be afforded were it my purpose to write an archeological treatise. Answering Sir J. Lubbock's contentions that primitive man must have been in a state of savagery because this is the actual condition of the present "outcasts of the race," or because industrial knowledge advanced from small beginnings, and because traces of rude customs remain even among highly civilized nations, the Duke of Argyll wrote as early as I869:

None of these arguments afford any proof whatever, or even any reasonable presumption, in favor of the conclusion which they are employed to support: first, because along with a 
complete ignorance of the arts it is quite possible that there may have been a higher knowledge of God and a closer communion with Him; secondly, because many cases of existing barbarism [we would now say savagery] can be distinctly traced to adverse external circumstances, and because it is at least possible that all real barbarism has had its origin in like conditions; thirdly because the known character of man and the indisputable facts of history prove that he has within him at all times the elements of corruption-that even in his most civilized condition, he is capable of degradation, that his knowledge may decay and that his religion may be lost. ${ }^{2}$

This explains the superstition that crept in over all the earth. Impurity is directly connected with a darkening of the intellect, and impiety together with a corrupt imagination will account for the cruel and debasing superstitions. Yet, though idolatrous in many instances, early man never lost his sense of religious duty and his belief in another world. Historically religion is purer the farther back we go, and the nearer it is to the original source.

Lewis H. Morgan's theory of an original herd family, ${ }^{3}$ from which the present form of marriage is said by him to have developed-a theory that was eagerly taken up by Socialists and made an essential part of their materialistic philosophyhas now been rejected by anthropologists. Long ago Edward Westermarck had written: "It is not of course impossible that, among some peoples intercourse between the sexes may have been al-

\footnotetext{
"Primeval Man," r99, 200.

"Ancient Society."
} 
most promiscuous. But there is not a shred of evidence for the notion that promiscuity ever formed a general stage in the history of mankind." 4 The hypothesis, he adds, is without foundation, and "essentially unscientific." Even among some of the savage and barbarous races of the present day polygamy is practically unknown, or positively prohibited. ${ }^{5}$ Morgan was wrongly and very arbitrarily forming his conclusions from a limited field of observation and his generalizations were without any warrant in fact.

As Robert H. Lowie, Assistant Curator of Anthropology in the American Museum of Natural History, shows, Morgan never advanced any proof for his preposterous theory of an original herd family in place of the union between man and wife. It was merely a conclusion that was required by his first principles of materialistic evolution, that man was descended from the brute, and he therefore made primitive man more immoral than the brute itself, without attaching any stigma to this immorality. His theory was advanced, says Lowie, "precisely as some evolu. tionary philosophers advance the axiom of spontaneous generation; and thereby placed it beyond the range of scientific discussion." 6 Summing

\footnotetext{
" "The History of Human Marriage," p. 133.

Ibid., p. 547 .

"Primitive Society," p. 57.
} 
up the evidence of anthropology on the present subject, the authority just quoted, whose conclusions no one can any longer seriously call into doubt, thus disposes of the entire question:

In the first place, marriage between single pairs is not absent, but common among the simplest tribes; and no ground whatever exists for assuming a condition of ancient promiscuity. Indeed, on the very lowest cultural plane we frequently encounter matrimonial relations that would be rated exemplary by a mid-Victorian moralist.

Exit, therefore, the Morganic hypothesis which for so many years was made the basis of Socialist philosophy and sociological literature. May it never again raise its ugly head! Yet it is a special convention of materialistic evolutionists that many of their number, to say the least, are not at all concerned about facts and spurn all attempts to prove their theories, since proofs, they admit, are not to be had. Their contentions are simply true, because they must be true. Materialistic evolution requires them. "As everybody knows," "As nobody doubts," are the favorite shibboleths. And this has been the attitude of so-called science for two generations of articulate-speaking men! Surely there could not have been less logic and a less sublime disiegard for empirical proof in the days of the mammoth and the cave man, even when the latter did represent society in its decline and not in its origin. It may be

'Ibid., p. 167. 
stated in passing that men like Westermarck and countless others have simply drifted with the currents when there was question of man's origin. The acceptance of a primitive state of savagery was made without further investigation and the writers assumed this basis for their subsequent studies and deductions.

Evidence without end could be given to disprove Morgan's contention, were there any further need of this. It will suffice to conclude this important matter with the scholarly words of Philo L. Mills in reference to the institution of marriage:

"The earliest designations for man and woman imply a sex difference, which, in combination with the idea of a matrimonial unity, point to a general persuasion in the past that: 'A man shall leave his father and mother, and shall cleave unto his wife, and they twain shall be one flesh.' Whether as Adjam and Hawah, Amei and Djaja, Ajer and Tanah, Ilai and Indara, we are brought before a single couple who are known as 'Lord and Life,' 'Father and Mother,' 'Water and Earth,' 'Strength and Affection.'

"This means that the earliest state was a monogamous one, for this we possess abundant evidence. Nay more, it implies that marriage belongs to the days of man's innocence, that it is especially sacred. Man was to 'increase and multiply,' even in the garden of God, though he was to do so subject to the higher law of reason and 
234 EVOLUTION AND SOCIAL PROGRESS

faith, he was not to live like the animals. For this purpose a special instruction on the sanctity of the tie was congruous, and this is hinted at in all the stories of the sanctity and happiness of the primitive couple, of their intimacy with the Creator." 8

Thus the studies of archeology, anthropology, primitive religions and primitive languages all point back to the absolute correctness of the Mosaic narrative. "He who had issued from the Creator's 'breath' - as in Malakka or Celebeshe who was so phenomenally conscious that he and his helpmate were one, could not but have heard the words of the same Creator in his sleep, opening his side and revealing to him his wife. 'Nin tulang ba-tulang yaka,' we can hear him say: This is now bone of my bone and flesh of my '̇esh.' 'She shall be called woman,' Dayang, besause she was taken out of man, Daya." 9

One thing, in fine, is clear and certain, that in every particular the Scripture account is borne out by tradition, history and all the sciences that touch upon the past ages of humanity. Primitive man could not have been a savage, if for no other reason than the fact that no savage race was ever known to have evolved itself out of savagery into civilization by its own efforts. Nor, we may be morally certain, could it ever do so. Culture and

\footnotetext{
8 "Prehistoric Religion," p. 241.
}

'Ibid. 
civilization have in every instance been brought about from without. Only through external influences, the coming of missionaries, explorers, merchants, or similar events, has a savage tribe ever been raised to civilization. "Herbert Spencer," says Dr. Dwight, "speaks in his 'Sociology' of the degradation from something higher of most, if not of all, the savage tribes of today." 10

Had man appeared upon the scene of life as a primitive savage, a sayage he would have remained, with the probability of sinking still deeper into a more hopeless decline. In countless instances we can directly trace the indications of a higher stage of culture, as in the extraordinary structures of Yucatan. So, to give but one example, the discoveries in the Polynesian Islands, says a writer, "prove that the uncivilized occupants of these islands were preceded by a people who were architects and builders, who possessed tools by which the stones they used were cut and chiselled, and powerful machinery by which enormous blocks were moved and fixed. And if the first men of these regions were savages, and their descendants are uncivilized, who built these temples and fortifications and Stonehenges? Between early man, as a savage, and uncivilized people of later times there is no place for these architectural remains." 11

10 "Thoughts of a Catholic Anatomist," p. r7o.

"B. C. Y., "The Remote Antiquity of Man Not Proven," p. 97. 
236 EVOLUTION AND SOCIAL PROGRESS

It is easy for an isolated colony to sink into barbarism, and such instances might be adduced. within historic times. An entire civilization can sink back into the state that followed upon the passing of Imperial Rome, and into decline still lower, as we shall show; but it is a moral impossibility for the savage to lift himself up unaided to civilization, for the very reason that he is a savage, without the energy and persevering striving after higher things that distinguish him from the higher stages of human development. Civilization can be explained upon no other assumption than that primitive man and woman did not begin their work on earth in a state of savagery, though there is no reason for denying that they passed successively through the paleolithic and the neolithic stages, which in no way indicate their degree of development as human beings. 


\section{WHAT PICK AND SHOVEL REVEAL}

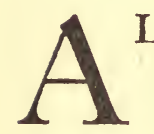

LL the ancient documents, such as the Homeric poems, point to the firm belief those which succeeded them. This is the moral of the hero legends. The Homeric heroes, in turn, look up to a nobler line from which they have descended. The earliest Egyptian relics tell of a purer faith than that which followed, even though its monuments were erected on a more magnificent scale. It is very interesting to note that Professor Conklin himself holds that human evolution has come to an end:

There has been no progress in the intellectual capacity of man in the past two or three thousand years, and it seems probable that the limits of intellectual evolution have been reached in the greatest minds of the race. Even in the most distant future there may never appear greater geniuses than Socrates, Plato, Aristotle, Shakespeare, Newton, Darwin. ${ }^{1}$

His argument if strictly pressed home would argue for a positive decline in the race ${ }^{2}$ "The great increase in nervous and mental diseases in

${ }^{1}$ Princeton Lectures. ${ }^{2}$ Ibid. 
modern life warns us that there is a limit to intellectual evolution." Now there is no proof whatsoever that men, intellectually as great as any of those mentioned by him, did not exist in pre-historic days, or were not to be found among the very races whose stray representatives we seek to reproduce from a few scattered bones. All recent discoveries prove more and more conclusively that the earliest human remnants are those of men with the same qualities of mind and body that we ourselves possess. The degree of ma. terial culture amid which we find them tells us but little of their intellectual powers. Greece was only in the beginning of her material development when she produced perhaps the greatest of all purely secular poets, Homer and his peers. Such too are the conclusion which a more advanced knowledge of archeology is gradually forcing upon men, even though the prepossessions of materialistic evolution still hamper many from forming independent conclusions. In the Smithsonian report for 1916 Sir Arthur Evans says:

The investigations of a brilliant band of prehistoric archæologists, with the aid of representatives of the sister sciences of geology and paleontology, have brought together such a mass of striking materials as to place the evolution of human art and appliances in the last Quarternary period on a far higher level than had ever been suspected previously. Following in the footsteps of Lartet, and after him Rivière and Piette, Profs. Cartailhac, Captan, and Boule, the Abbé Breuil, Dr. Obermeier and their fellow investigators have revolutionized our knowledge of a phase of human culture which goes 
so far back beyond the limits of any continuous story that it may be said to belong to an older world. ${ }^{3}$

In plain words, there is no substantiation for the tale of primitive savagery, which is called for only by the exigencies of materialistic evolution. Oh, for the freedom of science! The greatest obstacle in the way of modern progress, scientifically, morally and socially, is materialistic evolution, the very quintessence of concentrated intellectual darkness and autocracy, that permits of no conclusions save its own most arbitrary deductions.

The findings of the Spanish investigator Señor de Sautola, or rather of his little daughter, as long ago as 1878 , of the wonderful rock-paintings of the "Paleolithic age," were not recognized until corroborated by repeated new discoveries. Here there was question of the original hypothetical savages; and what did men find in their cave homes or meeting places on what we now know as the French side of the Pyrenees?

In their most developed stage, as illustrated by the bulk of the figures in the Cave of Altamira itself, and in those of Marsoulas in the Haute Garonne, and of Font de Gaume in the Dordogne, these primeval frescoes display not only a consummate mastery of natural design, but an extraordinary technical resource. Apart from the charcoal used in certain outlines, the chief coloring matter was red and yellow ochre, mortars and palettes for the preparation of which have come

"Sir Arthur Evans, D. Litt., LL.D., P.S.A., F.R.S. "New Archeological Lights on the Origins of Civilization in Europe." From the Smithsonian Report, p. 429. 
to light. In single animals the tints are varied from black to dark and ruddy brown or brilliant orange, and so, by fine gradations, to paler nuances, obtained by scraping and washing. Outlines and details are brought out by white incised lines, and the artists avail themselves with great skill of the reliefs afforded by the convexities of the rock surface.

But the greatest marvel of all this is that such polychrome masterpieces as the bisons, standing and couchant, or with limbs huddled together, of the Altamira Cave, were executed on the ceilings of inner vaults and galleries where the light of day has never penetrated. Nowhere is there any trace of smoke, and it is clear that great progress in the art of artificial illumination had already been made. We know that stone lamps, decorated in one case with the engraved head of an ibex, were already in existence."

Here therefore we stand at the beginning of human history, with the men once classed as savages, because evolution demanded such a supposition. Nor are these isolated instances. "One by one, characteristics, both spiritual and material, that had been formerly thought to be the special marks of later ages of mankind have been shown to go back to that earlier world." Never, adds, the writer of these lines, can he forget his impression as he stood at the first uncovering of a pre-historic interment in one of the Balzi Rossi Caves:

Tall skeletons of the highly developed Cro-Magnon type lay beside or above their hearths, and protected by great stones from the roving beasts. Flint knives and bone javelins had been placed within reach of their hands, chaplets and necklaces of sea shells, fish vertebra, and studs of carved bone

'Ibid., pp. 429, 430. 
had decked their persons. With these had been set lumps of iron peroxide, the red stains of which appeared on skulls and bones, so that they might make a fitting show in the underworld.

Colors, too, to paint his body, Place within his hand,

That he glisten, bright and ruddy,

In the Spirit-Land. ${ }^{5}$

Idolatry? Presumably so, let us say, though what certainty have we of the archeologist's interpretation? But none the less there is here admittedly a concept of religious duties and of a future life. Religiously these men may have been incomparably superior to thousands of supposed gentlemen and ladies who today grace the salons of the social world, but whose lives are often without a thought of God, or even of any higher or nobler things than personal gain and personal ambition. Spiritually they may belong to a stage far below the Cro-Magnon type. But idolatry itself, we contend, was but a degradation of that true belief which the first man and woman transmitted to the human race, which was preserved through certain channels to the days of Abraham, and which in countless races and tribes was gradually perverted and mingled with false doctrines and superstition, while the knowledge of a Supreme Being nevertheless remained everywhere, though confused more and more with polytheistic notions. The similarity of primitive

${ }^{5}$ Ibid., p. 430. 
religions points to these conclusions without any doubt.

Aside from the facts of the Sacred Scripture, there is the most explicit reason from history for saying this. History shows the growth of polytheism and the departure from the simplicity of the primal religion, open to direct and authentic verification, in the early and later cults of Egypt, Rome and Greece. Monotheism preceded polytheism, and the latter has even been scientifically attributed to a deification of the various attributes of the one God. However this may be, the notion of Godhead became more confused as time went on, and superstition gradually spread both in extent and grossness. Until the coming of Christianity men looked back to primal Revelation, while Christianity itself was "the new and full exposition of the first Revelation," the fulfilment of all type and prophecy.

Going back to the very earliest center of European civilization, we are now able to study the authentic facts as pick and shovel have disclosed them in our day. What follows is not the fancy picture of a novelist, but the calmly weighed statement of the President of the British Association for the Advancement of Science, made in his address delivered in 1916, at Newcastle-on-Tyne:

"It is difficult, indeed, in a few words to do adequate justice to this earliest of European civilizations. Its achievements are too manifold. 
The many-storied palaces of the Minoan priestkings in their great days, by their ingenious planning, their successful combination of the useful with the beautiful and stately, and last but not least, by their scientific sanitary arrangements far outdid the similar works, on however vast a scale, of Egyptian or Babylonian builders. What is more, the same skilful and commodious construction recurs in a whole series of private mansions and smaller dwellings throughout the island. Outside 'broad Knossos' itself flourishing towns spring up far and wide on the country sides. New and refined crafts were developed, some of them, like that of the inlaid metal work, unsurpassed in any age or country. Artistic skill, of course, reached its acme in the great palaces themselves, the corridors, landings, and porticoes of which were decked with wall paintings and high reliefs, showing in the treatment of animal life not only an extraordinary grasp of nature but a grandiose power of composition such as the world had never seen before. Such were the great bull-grappling reliefs of the sea gate at Knossos and the agonistic scenes of the great palace hall.

"The modernness of much of the life here revealed to us is astonishing. The elaboration of the domestic arrangements, the staircases story above story, the front places given to the ladies at shows, their fashionable flounced robes and jackets, the gloves sometimes seen on their hands 


\section{EVOLUTION AND SOCIAL" PROGRESS}

or hanging from their folding chairs, their very mannerisms as seen on the frescoes, pointing their conversation with animated gestures-how strangely out of place would it all appear in a classical design. Nowhere, not even at Pompeii, have more living pictures of ancient life been called up for us than in the Minoan Palace of Knossos. The touches supplied by its closing scene are singularly dramatic-the little bathroom opening out of the Queen's parlor, with its painted clay bath, the royal draught-board flung down in the court, the vessels for anointing and the oil jar for their filling ready to hand by the throne of the priest-king, with the benches of his consistory round and the sacred griffins on either side. Religion, indeed, entered in at every turn. The palaces were also temples, the tomb a shrine of the great mother. It was perhaps owing to the religious control of art that among all the Minoan representations-now to be numbered by thousands-no single example of indecency has come to light." 6

Rather startling, is it not? And rather a striking contrast to the indescribable moral decline of this same civilization in the classic days of Greece and Rome. In the meantime, during all these periods, Paleolithic and Neolithic man was roaming the forests and dwelling in caves, often the decadent descendant of perhaps just such a

${ }^{6}$ Evans, op. cit., pp. 442-445. 
civilization, which itself may have fallen into decline, or from which he may have wandered or been driven out into the new and distant lands.

"Above all else," says Dr. T. A. Clay, Professor of Oriental literature at Yale, "one of the greatest surprises is that the earliest peoples, instead of being barbarous and uncultured, were civilized and possessed culture of a high order." ?

The light is breaking. Again the Mosaic account is verified. As Dean Harris says in the Ontario Archeological Report for I9 I7: "Assyriologists and Egyptologists have opened new avenues of exploration, and from the ruins of buried cities proved the accuracy of the Mosaic account of the Noachic Flood, the patriarchal period and the Isaian prophecies. From the monuments, clay tablets and cuneiform scripts now in the British museum, the Pierpont Morgan and University of Pennsylvania treasures, and from collections preserved in the libraries of the universities of Europe and America, archeologists and oriental scholars assure us that the records of the Old Testament are in accord with many of the remarkable facts written on the monuments recently uncovered in the historic lands watered by the Tigris and Euphrates rivers.

"The newly discovered tablets and terra-cotta writings triumphantly bear witness to the truth of

7 "Pushing Back History's Horizons." 


\section{EVOLUTION AND SOCIAL PROGRESS}

the statement of the ethnographist Balhi, ${ }^{8}$ that: 'No monument, either historical or astronomical, has yet been able to prove false the books of Moses; but with them, on the contrary, agree in the most remarkable manner the results obtained by the most learned philologists and the profoundest geometricians." "g

" "Atlas ethnographique du Globe," p. 93.

"Earth's First Man." Reprinted from the Ontario Archæological Report, I9I7, p. I7. 
THE DECLINE OF MEN AND RACES

LL history bears out the contention of a
primitive purity of religion, that was
gradually lost in proportion as men pro-
ceeded farther from the fountain source of the
first Divine Revelation. "Thus Diodorus Siculus," writes Father Robert Kane, "says that the old Chaldeans held a religion of pure tradition, and did not, like the Greeks, seek to discover something novel by the exercise of their own ingenuity. Plato tells of a reproach addressed by the Egyptian Sages to the Greeks. The Sages held that the true religion was the one handed down from generation to generation, and they blamed the Greeks for ignoring this. It is a rule of Aristotle, often also insisted upon by Plato, that to discover the truth we must find out what was said of old, what was the primitive doctrine, for this was the teaching of God. It was the opinion of Socrates that our early progenitors have transmitted to us sublime lessons taught originally from on high. There are many similar assertions to be met with in Cicero who constantly declares an- 


\section{EVOLUTION AND SOCIAL PROGRESS}

tiquity to be the best guide in religious belief. Lucan's line is well known, as an echo of universal thought: 'Dixitique semel nascentibus Auctor, Quidquid scire licet.'-'Whatever it was right for man to know, the Creator made known to His first creatures.'

"Again the most excellent maxims of morality have been found not only among the Jews, but also among the Persians, Babylonians, Bactrians, Indians, Egyptians, Arabs, etc., who all concur in assigning the origin of these maxims to a primeval tradition, and in asserting that religious truth was first communicated to earth from Heaven. There must be some foundation for this." 1

Of the decline of civilized nations into barbarism or semi-barbarism, we have countless instances. We need but refer to the sinking of the entire world into such a decline with the fall of Rome and Greece. Even the barbarian conquerors of the empire of the earth had in many instances imbibed no little of the culture of Rome, with whose civilization they had been made very familiar. Yet when the world gradually emerges again into the light of history, after the long darkness of unrecorded days, what do we witness but a civilization beginning anew with the most rudimentary training in agricultural pursuits, taught it by the patient and heroic monks!

Except for the Church, literature and art, with

${ }^{1}$ Robert Kane, S. J., "God or Chaos," pp. 183, 184. 
all their traditions, would have wholly disappeared, and it is no exaggeration to say that in place of London, Paris, New York or Berlin, there might now be but roving hordes of savages. This is a strong saying, but the more deeply we study history, the more the possibility of such a continuous decline that existed then, must be borne in upon our minds. There are certain sections of our glorious modern centers of supposed culture which morally and religiously are even now not far removed from the stage of savagery, and which doubtless have sunk far below the morality of many of the tribes now known to anthropology as "primitives."

It is always easy to lapse into savagery even in the midst of our material culture, as divorce, and birth control, and ugly slums, and the World War, and the modern paganism, and the cult of nakedness, and Bolshevism and profiteering in the social world make sufficiently clear. It is not the feather stuck in the hair that constitutes the savage. Last and yet not least, we may mention "the strange dismaying things cast up by the tide of war," as Windle strongly says, "those traces of primitive fatalism, primitive magic and equivocal divination which are within general knowledge." It is here again that material civilization and decadent barbarism have fallen to a common level. Thus our parlor Spiritism finds its perfect parallel among the savage tribes of today. 
It is part of the same necromancy and incantation that followed in the wake of a purer religion, and against which even the Jews had constantly to be guarded, and often without avail. A typical parallel to Mr. D. Home's most inexplicable feat of what we call "self-elongation" is thus given by a Catholic missionary:

Father Orinel, C.S.Sp., in Madagascar, happened to be present at one of the trombas (incantations) of the natives. A girl acted as medium; two aged women were her controls, or, as Spiritualists would say, sitters. Incense was being burnt in pans, which the two aged women passed from time to time in front of the girl's face. They then made a series of passes with hazel wands over the girl, who became violently agitated. Her bosom heaved, her eyes seemed as though imploring the lookers-on, whilst the latter howled forth a menacing kind of prayer. The girl bounded to her feet, saying, "I am here," which meant-so the missionary says-that the spirit had descended upon her. An indescribable delirium took possession of all present. "What was my astonishment," wrote the missionary, "to see the girl's features change as I looked; it seemed to me that her limbs became larger, her height much greater. I rubbed my eyes. No, I was not the victim of an hallucination; the possessed girl had grown taller, until she was fully a head over each of the two old women. The girl then named the disease of each sufferer who passed in front of her, though her eyes remained fixed, motionless, and gazing into the distance. The aged women repeated the passes; the figure of the young girl resumed its normal size, her features relaxed, her eyes recovered their natural expression, and at last she said, 'I go.' The spirit was gone. The tromba was finished." "

For this there is no explanation except that which the Scripture gives: the ancient Satanism.

'Annals of the Propagation of the Faith, Febr., 1918. 
Here, too, the Divine Books offer the only explanation that can satisfy the human mind. It matters not how much in our modern seances is merely trickery or deceit, as is commonly claimed, or, how much more must be attributed to telepathy and other psychic phenomena, the one pertinent fact that needs to be stressed is that men do believe they are practising necromancy, and this, from an anthropological point of view places them, in that regard at least, on a level with the decadent state of savagery.

No serious student of history can question the fact that there has been a constant devolution as well as evolution. Ancient Egypt, when it rises into notice at the misty dawn of history, is said by historians to have even then begun its decline. This refers in particular to a far greater purity of religious worship to which its earliest monuments point. As Correa Moylan Walsh, in the first of his volumes, written from a strongly materialistic point of view, says: "Of the very earliest peoples that have risen to a high culture, our knowledge, though unsatisfactory, is indeed mostly of their declining and low stationary periods," 3

Even the so-called "primitive" races of today that are thought-though this cannot be proved, and in view of the Flood cannot be held-to have come down but slightly changed from the s "The Climax of Civilization," p. go. 
earliest pre-historic days, show that: "Not an evolution but a degeneration has been going on for countless ages, and what we see in the buried remains no less than in the jungles of the Far East is not the gradual rise from a semi-simean or a pithecoid type, but on the contrary a progressive deterioration from an ideal, pre-Australian, preNeanderthal form of high-brow features, a cast of man almost European in his appearance." 4 As specific evidence are cited the facts that the negrito is less simean than the Australian; the negrillo, than the modern African; the primitive Indonesian, than the modern Malayan; the pre-Mongolian Aino, than the modern Japanese. Yet these "primitive" races themselves have fallen from a higher state. We have already alluded to the conviction that was forcing itself even upon Herbert Spencer's mind, that most, if not all, the savage races of today are degenerates from a superior stage of culture.

The summary conclusion which history inevitably leads us to form is that primitive man was able to develop his material civilization in the course of time only because he did not begin as a savage, while the present savage cannot rise to civilization unaided, and through all the course of history has never been known to do so, simply because he is a savage, which primitive man was not and, morally speaking, could not have been. Had

"Philo Laos Mills, "Creation Versus Evolution," p. 10. 
man begun as a savage, a savage he would be today. Man has always within himself the reason for his fall. Self-exertion alone can avert it. This precisely is wanting in the savage, who rather tends to sink still lower, unless assisted from without.

The net result of all our modern discoveries no less than of our wider historic knowledge is that man began as now we know him, although amid less favorable surroundings and in a far lower stage of material development-the very lowest hitherto discovered by archeologists, it may be. Yet these stages of material development are not necessarily any index to his intellectual and spiritual qualities, which essentially were always the same as now in their nature, and which in their actual exercise may at least have been as perfect in the first man that came from the hand of God as in the highest type of modern men. But material civilization developed constantly, while the decline into barbarism and savagery in various parts of the earth, to which men had gradually come by adventure, by accident, or by necessity, took place we may presume before the Flood, as it was resumed after that period. The Flood itself is an outstanding fact of science. The Scripture account enables us also to explain the diversity of races sprung from the three sons of Noah. The same material development continued anew in the earliest centers of culture, 
254 EVOLUTION AND SOCIAL PROGRESS which by all are placed in the East, and the same lapse into savagery occurred away from these centers. It is a decline which from monuments, traditions, and history we can clearly show to have run its course within our own historic times. 


\section{THE COURSE OF HISTORY.}

TN the Gallery of Art of the New York Historical Society is a series of five paintings by 1 Thomas Cole depicting "The Course of Empire." On each canvas the same landscape is pictured, though seen from different angles, while the changes wrought by the hand of man pass over the successive scenes. The lesson of the artist is well worth careful study in our day.

Conformably with our popular sociological notion, the first picture bears the legend, "Savage State," though we know historically that no civilization has ever evolved from savagery unaided, while in countless instances the clear evidence still remains of the descent of savage tribes from higher stages. But overlooking this we come to the picture itself.

In the distance is a hill that ends abruptly at the dark waters of a bay, which are faintly seen beyond a wild and rocky landscape, with gorges, thickets and storm-beaten trees. On the crest of the hill an isolated rock is balanced, left there by the erosion of the waters in the earth's prime. 
The clouds that roll about it, sullen and black as night, are slowly being dispelled by the breaking dawn. Over a brook that whitens into foam a roe is leaping, pursued by a huntsman clad in skins and holding in his outstretched arm a long and sinuous bow. Dimly seen afar, a troop of his fellows dance in the misty light, while on a high plateau a circle of wigwams stands, with a great column of fire and smoke ascending. It is, let us say, the morning sacrifice.

Man is man precisely as now we know him. In his song and dance we behold the beginnings of art. His arrow overtakes the prey and his mind is keen, alert and resourceful. The morning holocaust was offered to the one true God, and the first art did Him worthy service in song and rhythmic dance. Our economic preconceptions, indeed, make primitive man look to the chase for his sole support. While this is true of the savage fallen from a higher state into the lowest decline, it does not follow that husbandry and the pastoral life were not soon developed by the first human beings, as Scripture indeed tells us that they were. "The Arcadian" or "Pastoral State" is the title of the second painting. Ages passed before man had risen to the material comfort here portrayed. In the distance is the familiar hill with its mighty boulder. The flocks are grazing on a green slope, and on an upland tract of soil a ploughman traces his furrow, plodding after the laboring kine. 
Quite to the front of the pictures sits a primitive Euclid marking geometric figures with a rod in the soft earth. The rivulet is now crossed by a bridge of stone slabs on which a "little boy blue" is drawing with red ocher a human figure, just such as may be seen today on the paved sidewalks of Manhattan. Another child is gathering flowers, while the mother stands near, a dignified, matronly figure with spindle in hand. Beneath a shady tree a rustic Tityrus is playing on his oaten pipe to the dancing girls. Religion, too, occupies its proper place, for set conspicuously upon an eminence overlooking the little village by the bay, a stately temple rises. Plain shafts support the roof. In its early simplicity was manifest a purer worship than when in later days the hills were crowned with temples, and false gods and goddesses were numberless as the vices of the men who conceived and made them. Thus Polytheism was to take the place of the first monotheisitic religion. Yet this was never to be wholly lost at any period.

But a transformation now passes over the scene. "The. Consummation of Empire" is the new theme. There to the right we recognize the distant hill, with its balanced boulder untouched by the hand of men. Through the landscape flows the broad water of the bay, and on both sides monuments, palaces, temples and public edifices, Doric, Ionic, Corinthian, crowd upward from the 
blue waters. Galleys of war throng the harbor and graceful barges spread their silken sails of varied colors, that glow reflected in the tide.

To the left is a massive Doric temple, with its carved pediment. Long colonnades stretch upward to some spacious administrative hall, with its serried columns and its crowning dome. On the opposite shore magnificent palaces rise, with rich statuary, huge vases and luxurious draperies, Tyrean purple flashing against silks of white and gold. Wealth and art have here their home. Lifted aloft on clustered pillars stands a whiterobed goddess holding out in her hand a Winged Victory. A wall with stately caryatids leads to the massive bridge over which a triumphal procession moves. On his exalted throne the victor is borne along, proud in imperial scarlet, while below him throng the horsemen, and white-vested counsellors follow in solemn ranks. Before him rises the triumphal arch, surmounted with glittering armor and arms. Wide-spread, lavish drapery hangs in gorgeous folds from bridge and monuments. Large in the foreground, prodigally designed, a fountain fills its marble basin with the waters of the selfsame spring over which, in that misty morning, far away in the past, the roe had leaped, pursued by the eager huntsman clad in the skins of the chase.

Human glory and material development are here in their apogee. Man could do no more 
than this. Art, architecture, music, sculpture; the fruit of the loom; whatever wealth can purchase and the human mind design in outward magnificence and brilliancy; ease and opulence; culture and luxury; empire and victory-all are combined in one narrow canvas. It is material evolution at its height; and yet it marks a decline, a supreme failure at its height of triumph. In place of a simple and pure religion, with its one true God, there is here a decadent polytheism. In place of freedom, contentment and true happiness that wait on toil and virtue, there is here a cringing spirit and a world-dominating ambition. Wealth, vice and corruption have replaced the pure joys of the domestic hearth. We still continue in our mistaken theories falsely to gauge man by his surroundings. Yet even in early Rome there was more hardy virtue, more genuine liberty, more true manhood and pure womanly virtue, than in the full noon-day of the Empire's glory, when St. Paul could see in it nothing but cruelty, lust and greed; a gilded sepulcher.

And now, as we would expect, comes "Destruction." A gloomy pall overspreads the sky. Faintly through the darkness, as of a world crumbling to ruin, can be seen the distant hill with its solitary, isolated boulder. Red flames are bursting forth in a mighty conflagration from the palaces to our right. The pall of cloud is a pall of smoke from the city doomed to destruction. 
Men and women, clamoring and falling beneath the swords of a barbarian soldiery fill the foreground of the scene, where the plashing fountain is clogged with the bodies of the dead and dying. Dense multitudes, with agonized faces, are rushing to the water's side, where the massive bridge has been broken away and a meagre structure spans the stream, over which the struggling masses pour, falling precipitous into the engulfing waters. The black waves are faintly lit by the ghastly conflagrations of the sinking ships, filled with despairing fugitives. Loot, murder, butchery; death and horror everywhere; while blazing firebrands are carried through the streets.

By the fountain-side a gigantic warrior-figure had been erected, dominating all the scene. With shield advanced, body tensely stretching forward, and the unvanquished sword in his sinewy right hand, it was the true embodiment of the nation's ideals of force and might. By these, and by the skill and craft of statesmanship had the great empire beeen created. Written over all was the motto of the modern superman, the same in business as in politics and war: "Let him take who can." But now the sword-hand of that soldierimage was broken at the wrist; the head, with cold, relentless and imperious eyes, lay shattered on the pavement; and the edge of the protecting shield was broken by the missiles of a crushing defeat. 
Human power, glory, art and riches had overreached themselves. A purely materialistic development, losing sight of the things of the spirit, defying the restraints of religion, creating its own gods after the conceits of its own heart: Mars, Mammon, Venus, had produced the authentic superman, the apex, as we are proudly told in our own material days, of materialistic evolution. But the day of vengeance was not far off, as it must come to every nation that sinks to this decline, no matter what may be its material triumphs in war, in commerce or in art.

And then, last scene of all, "Desolation." A solitude far other than that of primal wildernesses, the solitude of Babylon, and Nineveh and Tyre. The moon is silently looking down, half veiled in clouds. Its light falls on the jutting hill with its lone boulder, still resting firmly balanced as when man first looked on it. Masses of carved stones show where the proud palaces had once stood and the white city lay, sunk in luxury, vice and greed, and in all that this same pagan materialism taught anew in our day, as if it were some unheard-of acquisition, proudly conned today in schools and universities, practised in high places and made the common argument among the masses. It matters not whether we call it by the name of Dagon or Astarte worship, a Monist creed or a humanitarian cult, eugenism or birth control, a proletarian dictatorship or an orgy of 


\section{EVOLUTION AND SOCIAL PROGRESS}

profiteering. It is always the same dull thing, under different names, and adapted to different times, which the Scripture calls "the world," that world for which Christ said that $\mathrm{He}$ would not pray, the world of the three concupiscences which must first be idolized, under the title of some godhead or some science, and thus be suitably dignified before it can be proposed for worship.

But the pride of "the world" passes while the Word of God remains. An arch is left-as we return to our painting-which shows where stood the massive bridge across which poured the mighty pageant in the day of triumph, when all ambitions had been achieved. Stray pillars, here and there, stand out from the bare landscape and white stones project from the brown earth. In a broken basin the fountain gurgles, as it flowed of old at the dawn of human life, and close before us, in desolate magnificence, a solitary column still remains, last mournful token of the vanished splendors. On its broken capital a black heron broods over her nest of straws, while amid the fragments at its base the shrubs and ferns are growing, and the venturous ivy climbs up to the broken acanthus leaves that crowned it in the day of its glory that has passed away forever.

And what of the descendants of those men and women who had once populated this solitude, of the few who in that night of horrors sought safety in the hills or were dragged away into barbarian 
slavery? Who knows, but some acheologist may discover them in our day and class them with the "primitives," the supposed original undeveloped savages. With the aid of God's Church a new cycle may then begin for them leading to a purer and nobler height of true Christian civilization. 


\section{"THE FOOL HATH SAID"}

$7 \mathrm{HE}$ conclusions arrived at are plain. $\mathrm{Hu}-$ man history, as every trustworthy evidence points out, did not begin with a state of savagery. While it is true that the race slowly advanced in its material development, there is no reason for asserting that the physical, intellectual and spiritual qualifications possessed by the first man upon this planet were not essentially the same as those of the races that exist today.

Materialistic evolution, from clod to amœba, from amœba to man, is worse than fable or myth. It is an incubus on science, and in the moral order, the great source of social irresponsibility, vice and crime. For the modern rationalistic school and the modern Socialist philosophy, religion is but the product of fear and nature worship. In blind defiance of reason, with its clear insistence upon the need of an intelligent, personal Creator, self-existent of His very nature, and thus essentially necessary, infinite, absolute and immutable, the materialistic evolutionist makes his blind act of faith in an uncreated matter, eternal and in- 
finite, and in an unpropelled force coming from nowhere. But matter we know is not necessary; it does not exist of its very nature, since that offers no reason for its existence or non-existence. It undergoes constant changes; it is dependent upon a thousand conditions and circumstances; it is finite and can be numbered; and it passes from motion to rest. It is not therefore either immutable, or absolute, or infinite in any sense, even in its activities. These qualities can be attributed to God alone. Our reason demands that we must finally come to a self-existent being, that can have no cause outside itself, but exists eternally by its very nature. That is God.

Materialistic evolution contradicts reason no less when it again postulates, without one spark of evidence, the unaided transition from dead clod to living being, in spite of the admitted impossibility of spontaneous generation. And lastly, to pass over all the minor chasms that have never been bridged, it contradicts reason the third time when it would trace back to brute instinct the essentially different and wonderful quality of intelligence in man. In fine, materialistic evolution has proved nothing and can prove nothing in all its long series of assertions, made without any sustaining evidence. To accept it is the height of credulity and superstition, a stage below that of fetishism, totemism and idol worship, which with all their crude ignorance are lighted by at least 


\section{EVOLUTION AND SOCIAL PROGRESS}

that one ray of human intelligence by which men see the necessity of admitting a Supreme Being other than world-matter. Even this ray does not penetrate the dense night of materialistic evolution. Its head is plunged deep into the mire of cosmic matter where it can neither see the brilliant light of God's great verities nor hear the eternal thunders that are sounding $H$ is praise through the rolling spheres. For the heavens proclaim His glory and the earth is the work of His hands. Well did old Carlyle drive home this truth when in 1876 he wrote to the London Daily Tribune:

$\mathrm{Ah}$ ! it is a sad and terrible thing to see nigh a whole generation of men and women professing to be cultivated, looking around in purblind fashion and finding no God in this universe. I suppose it is a reaction from the reign of cant and hollow pretense, professing to believe what in fact they do not, and this is what we have got; all things from frog spawn; the gospel of dirt the order of the day. The older I grow-and I now stand on the brink of eternity-the more comes back to me the sentence in the Catechism which I learned when a child, and the fuller and deeper its meaning becomes:

"What is the great end of man? To glorify God and enjoy Him forever!" No gospel of dirt, teaching that men have descended from frogs through monkeys can ever set that aside. ${ }^{1}$

There is the pith of the matter, and Carlyle has Windle to agree with him when in his "Theophobia: Its Cause," the latter attributes this nine-

1 "Twenty-eighth Annual Archæological Report" of the Ontario Provincial Museum, pp. 61, 62. 
teenth-century materialism largely to the cant and distorted piety that in so many instances succeeded the solid doctrines and devotional practices of the Church, with its invincible background of reason. The evidences of credibility render Catholicism acceptable to the human intelligence, while its sweet reasonableness disposes of the extravagances that made religion so repellent to many scientific minds in the Victorian period. Yet if we can point to the apparently good natural lives led by not a few men, who, like Darwin, have eliminated religion from their thoughts, while perhaps they never actively opposed it, we must remember that they are living upon the capital of religious traditions and customs handed down to them by their ancestors:

These people are really pagans living in the Christian era, retaining many of the excellent qualities which they owe neither to nature nor to paganism, but to the inheritance, perhaps involuntary and unrecognized, of the influences of Christianity. Many of these people are kind, benevolent, scrupulously moral. They have not learned to be such from nature, for nature teaches no such lessons. Nor have they learned them from paganism, for these are not pagan virtues. They are an inheritance from Christianity. Those, therefore, who built arguments as to the needlessness of religion on the foundation that persons without any belief in God do exhibit all the moral virtues, build on sand.'

Materialistic evolution means of necessity the denial of freedom of the will, for this cannot be attributed to purely physical and chemical proc-

${ }^{2}$ Windle, "Science and Morals," pp. 27, 28. 
esses, and hence it does away with all virtue or guilt, all responsibility, and logically leaves man to live according to his unbridled passions without regard to the rights of his fellow men. Materialistic evolution means the denial of all authority, since without God there is no authority that can exact obedience from men, who by nature are equal. Force only can then constrain them to do the bidding of another. "No God, No Master," the motto of the anarchist, is the logical watchword of every atheist, though he may in practice rise superior to the conclusions which his creed necessitates. "We shall take all we can get," is the cry of the radical Socialist as of the godless profiteer. There is no vice so low, no crime so abhorrent, that it must not be defended if materialistic evolution is to be the accepted creed. A creed we call it by courtesy, but since the faith it demands of its adherents is without any of those invincible evidences that make the acceptance of Christianity imperative to right reason, we can properly rank it only as a superstition. Scientific foundation it has none at all. These are hard words, hard and inexorable as truth itself, but they are not bitter words. Would that they might convince men of the greatest of all social truths, that without the Church there is no hope for society. At the age of seventy-three Spencer himself had been forced to confess: 
So conspicuous are the proofs that among unallied races in different parts of the globe progress in civilization has gone along with development of a religious system .... that there seems no escape from the inference that the maintenance of social subordination has peremptorily required the aid of such an agency.

Materialism, therefore, means everywhere the ruin of civilization. It may live for a time upon its Christian inheritance, but sooner or later must sink down to the level of the cruelty and vice of decadent pagan Rome, whose corruption had advanced so far that even Christianity but delayed its fall. The Church could save it to just the extent that her doctrines were practically received. Materialism means the abolition of right and wrong. Let but the masses seize upon this idea and anarchy is the order of the day. Materialism as a creed for a few intellectuals in university chairs, for the brazen things of fashion that coddle a lap-dog to their heartless breast, or for the men of wealth who would grasp the resources of nations or govern the destinies of the world in accordance with their ambitions, may be deemed good enough as a working policy that dispenses them from all conscience and religion. But it were prudent for them not to whisper this to others: "Hush-let's not say that aloud. Let us keep that as our secret." Woe to them once the masses follow out the logic of the false principles 3 "Autobiography," II, p. 467. Quoted by Prof. O'Rahilly in Irish Ecclesiastical Review, Dec., rgrg. 
they are now teaching them. For if these were true, if materialistic evolution were not, as it is, a lie from the nethermost depths of hell, then Blatchford had been perfectly right when he fearlessly said of the criminal who murdered a child for the few poor coppers it held in its hand, and then threw its little body into a ditch: "He is not to blame-not to be punished."

That is the social progress promised us by materialistic evolution, and given us by learned university professors, in stately cap and gown. In no small part the rationalistic world has already achieved it in its disregard for human life, its birth control, its obscenities and nudities that are paraded without any sense of shame, its defiance of sex distinctions, its destruction of the home, its irresponsible wealth, its premeditated slowing of the processes of labor, its enactment of laws that imply a despair of virtue and self-control except when enforced by police authorities, its revolutions upon revolutions and proletarian dictator. ships beginning with loot, lust and murder, and ending, God knows how! and add to this all the mass of vicious or prurient literature which is the product of debased minds and race degenerates, but which is trumpeted to the four winds of heaven by all the means at the disposal of the most unscrupulous of advertising agencies. Yet all this is logical, supremely logical, in the full light of what is being taught as materialistic evolution 
from the great chairs of learning. But what sane man can fail to see-to paraphrase the Scripture word-that from the point of view of science and of reason it is all, if not dishonesty, pure folly. Verily: "The fool hath said in his heart: there is no God."

Well did the great Bishop Ketteler say: "It has been reserved for our own time to repeat on earth the crime of the Angel, who, with full knowledge of his relation to God, dared to revolt against Him; we have in our midst not one or a few atheists, but a whole generation of atheists. As long as the stones exist of which these walls were built, as long as the sun shines upon the face of the earth and proclaims the glory of Him who made it, as long as the dew drops from heaven to refresh the flowers of the field, as long as the heavenly showers of grace sink into the soul of man to waken it to Divine life and Divine love, such a cold-blooded, diabolical doctrine has not come forth out of the mouth of man." 4

No, religion is not begotten by fear, as sociologists would tell us. Fear could but bring about its outward manifestation. Mythology is not the beginning, but the degradation of religion. Ancestor worship and nature worship are not its causes, but only false expressions of those spiritual urgings and dispositions inherent in all men, with-

" "Predigten," II, p. 162; Metlake, "Ketteler's Social Reform," p. 54 . 


\section{EVOLUTION AND SOCIAL PROGRESS}

out whose previous existence idolatry itself would be inexplicable.

Indebted to God for all his being, man feels his dependence on his Creator: "He has made us and not we ourselves." Hence religion is coextensive with humanity. Its perversions by man in the course of time are easily accounted for by the depraved imagination which follows upon impurity and vice. All the evidence of history and tradition, when carefully followed, will be found gathering slowly together in a Primal Revelation. Yet this was never all perverted. It was still preserved in certain channels from Adam down to Abraham; was amplified by later communications of God with man, in the days of the Old Law; until in every detail, the great prophecy of the promised Messiah had been given. The very time and place of His coming were definitely foretold and His virgin birth: "Behold a virgin shall conceive, and bear a son, and his name shall be called Emmanuel," i.e., "God with us." 5 So through the barren deserts of an idolatrous paganism the fructifying stream of Primitive Revelation flowed, and widened out among the chosen people, until the promise given to our first parents was fulfilled in all its completeness in the Great Mother with her Child, that was to crush the serpent's head. Like an echo from that faroff day sound the words of the "good news," as

'Isaias, VII:I4. 
from the lands of the East, nearest to the origin of our human race, came the wise men led by the guidance of the star: "And entering into the house, they found the child with Mary his mother, and falling down they adored Him."

Such was now the source from which all true social progress was to flow in the years to come. "Our Jesus, who is reproached with having been born in a village, and not in Greece or any wellknown country," wrote Origen against Celsus, "who is despised as the son of a poor laboring woman, has yet been able to stir up the whole inhabited world, surpassing the influence of Themistocles of Athens, Pythagoras, Plato, or any philosopher, ruler or leader in any part of the world." Must not everyone, he continues, who carefully studies these facts, be struck with amazement at the victory of this man? Yet more than man was $\mathrm{He}$ whose coming the great social prophet Isaias had proclaimed in those words which the Christian world repeats with him today: "For a child is born to us, and a son is given to us, and the government is upon his shoulders: and his name shall be called, Wonderful Counsellor, God the Mighty, the Father of the World to come, the Prince of Peace." " Here, then, and not in materialistic evolution, must be sought the source of all our future social progress.

'Ibid., IX:6. 


\section{H A P T E R XXI V}

\section{WHAT THE MOUNTAINS SAW}

T $\mathrm{N}$ the works of a Slavic author occurs a dialogue between two mountains, the giant 1 Finsteraarhorn and his companion, the Jungfrau. They have been sleeping for immeasurable periods of years, and as they awaken the elder of the two, the darksome Finsteraarhorn, looks down from the clouds and tells of what he sees: "Nothing but ice and snow." There are no trees, no grass, no living things. "Only endless ice and snow." And so they sleep again.

Ages pass and they awaken for the second time.

The bonds of the ice are broken. The lakes and tarns lie silvern and blue on the sunny earth. The hills are covered with trees and the meadows carpeted with green, inwrought with many-colored flowers. All this the Finsteraarhorn recounts to his companion, and he notes especially how the landscape is "dotted with tiny creatures," minutely small as seen from that great height, whom he calls "human beings."

But the interest of the ancient mountain flags, 
and together they sink contentedly into another sleep of centuries.

A third time they awaken. There is thunder in the air and the flash of lightning far below them. It is not the turmoil of the clouds, to which they are accustomed, but the roar of cannon, the fire of artillery and the bursting of shells. The gorges and the cliffs re-echo with the cries of fighting men and the dreadful din of battle.

The few tiny "human beings," which the elder mountain had perceived before, dotting the meadows and the hillsides, have now multiplied and are gathered into mighty cities. In the open field they have dug long trenches around the earth. They are surging, destroying, and slaying. The ground beneath them is torn by shells, the air above them is dark with smoke and vapor. "What can it mean?" the old mountains ponder, with their heads close to each other. But they soon weary of the riddle and pass into slumber.

A fourth time they awaken. The air is cold and keen and bright. "What is it you see?" the Jungfrau inquires.

"Ice, snow and ice, all about us," the Finsteraarhorn answers from his crystal outlook. "Ice and eternal snow; cold, sparkling, dazzling snow. All else has disappeared." The rising sun is shining upon white polar fields and silent glaciers, and upon a stark and frozen world in its cerements of snow, where for centuries all life has 
been extinct. "It is well," the Jungfrau remarks. "Let us back again to sleep.";

And is this then the sum of human life and endeavor? Is it without any further significance, as the materialistic evolutionist teaches? Glaciers and snow, and then the brief period of man, and glaciers and snow again, eternal glaciers and snow! Or rather shall the earth, as many hold, and as the Scripture tells us, be wrapped about in melting and consuming fires, as when coming out of the great void of space some blazing cosmic bodies should smite it in a mighty impact and flame should be the end of all. And can we hope and live for nothing more?

Materialism was summed up, in its true meaning and all its social consequences, centuries ago in the Book of Wisdom. There we read the tale of Babylon; of Jerusalem in the day of Christ; of London and Petrograd; of Paris, Berlin or of New York, wherever and how far soever materialism has produced its fruits:

For they have said, reasoning within themselves, but not rightly: The time of our life is short and tedious, and at the end of a man there is no remedy, and no man hath been known to return from hell:

For we are born out of nothing, and after this we shall be as if we had not been: for the breath in our nostrils is smoke: and speech a spark to move our heart,

Which being put out, our body shall be ashes, and our spirit shall be poured abroad as soft air, and our life shall pass away as the trace of a cloud, and shall be dispersed as a mist, 
which is driven away by the beams of the sun, and overpowered with the heat thereof:

And our name in time shall be forgotten, and no man shall have any remembrance of our works.

For our time is as the passing of a shadow, and there is no going back of our end: for it is fast sealed, and no man returneth.

Come, therefore, and let us enjoy the good things that are present, and let us speedily use the creatures as in youth.

Let us fill ourselves with costly wine, and ointments: and let not the flower of the time pass by us.

Let us crown ourselves with roses before they be withered: let no meadow escape our riot.

Let none of us go without his part in luxury: let us everywhere leave tokens of joy: for this is our portion, and this is our lot.

Let us oppress the poor just man, and not spare the widow, nor honor the ancient grey hair of the aged.

But let our strength be the law of justice: for that which is feeble is found to be nothing worth.

There is the philosophy of materialistic evolution, and all that it implies. Nor is there any excuse for the men who lay down the false principles from which these conclusions must be drawn. They are not merely criminals in the sight of God, but they are compassing the destruction of society and civilization. "But then again they are not to be pardoned," says the sacred writer, "For if they were able to know so much as to make a judgment of the world: how did they not more easily find out the Lord thereof ?"2 Terrible, too, is the responsibility of parents who expose

1 "Book of Wisdom," II:I-II.

'Ibid., XIII :8, 9. 
their children to such an education. It will not do to mince words where there is question of society, civilization and immortal souls.

No, glaciers and snow are not the end of all. There is more than the symbolic mountains saw, who like countless of our vain philosophers, poets, scientists and romancers, frivolously guess at the riddle of life, and then close their eyes and dream their dreams, after the conceits of their own hearts.

There is a lowly mount, too humble to have been even considered by the novelist's Jungfrau and dark Finsteraarhorn. Yet it alone was privileged to witness an event more thrilling and important than any these supermountains ever dreamed of in their superior wisdom. It is the mount of Calvary with its three uplifted crosses. In that scene they might have read the answer to all their riddles of the universe, all the problems of human life, its struggles, happiness, and seeming derelictions.

What indeed were man upon this earth, except for the love of the eternal God and the Cross of Golgotha. It is here that life acquires its true meaning and suffering all its worth. It is here that the massive mountains dwindle into nothing, compared with the preciousness of a single human soul, purchased at the price of the Death of a GodMan. It is here that all their centuried years are 
less than a pulse-beat of time, measured by that day of eternity wherein the souls of the just are destined to receive the endless reward for their love of God and neighbor. So only can those longings for happiness be satisfied which have not been placed in vain within the breast of every man. Here, then, must be sought the one great motive that alone can save society, perfect civilization and lead to lasting progress.

The true evolution of man, after the fulness and perfection of the Divine design, can come in no other way than that in which St. Paul brought it to the world, through the preaching of the Crucified. "The Cross wrought persuasion through unlearned men," wrote St. John Chrysostom, "yea, it persuaded even the whole world; and not about common things, but concerning God and true godliness and the Gospel way of life and the future judgment. It turned all men, even the very rustics and the utterly unlearned, into philosophers. For the noble ideals which taxcollector and fisherman were able by God's grace to carry into effect, could not even be grasped by philosophers, rhetoricians, rulers, not even by the whole world with its myriad efforts. What then did the Cross introduce? It taught the immortality of the soul, the resurrection of the body, the contempt of things present, the desire for things future. It made men angels; and thus all 
280 EVOLUTION AND SOCIAL PROGRESS

men everywhere are philosophers and exhibit every virtue." 3

Such are the true supermen and superwomen whom Christianity is able to evolve by the grace of God. To them we must look to lead the world to its highest heights of true social progress.

${ }^{3}$ In I Cor. hom. IV.3, cf. Irish Ecclesiastical Record, c.c. 


\section{INDEX OF NAMES}

Adami, roo.

Agassiz, 85 .

Allen, 62.

Alsberg, 174 .

Ampère, 107.

Anderson, 20, 21 .

Andrews, 212.

Argyll, Duke of, 83, 223, 224.

Aristotle, 71.

Augustine, St., 82, 96, 97, 98, IOI, 104, 117.

Balhi, 246.

Barrell, I12, I18, I19.

Basil, St., 98 .

Bateson, 88, 93, 100.

Bebel, 44, 147 .

Bergson, 7 1 .

Blatchford, 43, 17, 19.

Bolce, 13.

Bonaventure, St., 97.

Branco, 154, 157, 159, 160.

Breuil Abbé, $213,238$.

Broca, 164.

Brumpt, 182.

Buttel-Riepen, 173.

Carlyle, 266.

Chamberlain, 121.

Chrysostom, St., 279.

Cicero, 247.

Clay, 245 .

Clodd, 23.

Conklin, 168, 202ff., 237.

Crozier, 76.

Cunningham, 74 .

Cuvier, 74, 75.

Cyon, 184 .
Darwin, 27, 28, 31, 42, 65, $72 f f$., 90.

Dawson, J. W., 212.

Dawson, Sir William, 137.

Delage, $6 f f ., 86$.

De Lapparent, 58.

De Morgan, 36 .

Depéret-Wagner, 128.

De Vries, 84, 87, 138 .

Draper, 188, 2 ro.

Driesch, 86.

Driver, 283.

Drum, S. J., 196.

Dubois, 155 .

Du Bois-Reymond, 203.

Dwight, 79, 192ff., 235.

Eimer, 86, 88.

Ellicot, Bishop, I 12.

Elliot, G. F. Scott, $148 f f$., 158 .

Elliott, Hugh, 68.

Emery, 88.

Engels, 147.

Evans, 238ff.

Fabre, 67, 68.

Faraday, 39.

Ferrer, 15 .

Ferri, 16 .

Fleischmann, 28, 137 .

Fordyce, 80.

Frank, S. J., 134, 135.

Frumveller, S. J., Preface.

Galileo, $35 f f$.

Gerard, S. J., 43.

Goethe, 38, 59 .

Gray, 82 . 
Gregory, St., 38.

Gregory, Dr., 147.

Guibert, 210.

Guillot, Mgr., 32.

Guiterman, I45.

Haberlandt, 86 .

Haeckel, 18, 19, 22, 25, 31, $42 f f ., 82,83,143,144,145$, 1 $51,176 f f ., 188,2$ ro.

Harris, 225, 245.

Hartmann, 86.

Hertwig, 159.

Homer, 25, 237, 238.

Howlett, 2 ro.

Hull, S. J., 57, 58, 98, II 5, 137.

Huxley, 32, 35, 36, 4I, 60, 6r, $76,82,94,161$.

Isaias, 273.

Jerome, St, II4.

Joly, 2 ro.

Jones, Wood, r73.

Julian the Apostate, 38 .

Kane, S. J., 96, 247, 248.

Kant, 9, 10.

Kassowitz, 86.

Kautsky, 146.

Keith, I 59, 175, 205.

Kellogg, 28, 7 r, 86, 90, 91, 177 .

Kelvin, Lord, 63, 64.

Ketteler, Bishon von, 27 I.

Klaatsch, 159, 162, 173, 207.

Knabenbauer, S. J., 88, 97, 103.

Kohlbrugge, 172.

Kölliker, 86, 88.

Kollman, 171.

Korschinsky, 86, 88, 90.

Kramberg, 159 .

Lamarck, 3I, 73ff.

Laplace, II2.

Leo XIII, 95, 197.

Lewes, 4I.

Lodge, 43.

Loeb, 10.
Lombart, Peter, ror.

Lowie, 231.

Lubbock, 229.

Lucan, 248.

Lull, 63.

Lyell, 77 .

Macnamara, 159, I64, 207.

Malpighi, 31, 187.

Marconi, 39.

Marx, 15, 44, 49.

Maxwell, II2.

Mendel, 34, 86, 88.

Menge, 30, 177 .

Mercier, Cardinal, 9, 39ff.

Mill, 4r.

Mills, 233, 252.

Milton, 89 .

Mivart, $35,85,88$.

Moore, 62 .

Morgan, 147, $230 f f$.

Mortillet, 156, 210.

Moses, 107, 108, 128.

Muckermann, S. J., 34, 141 .

Müller, 31, 187, 203.

Nägeli, 7r, 86.

Newman, Cardinal, 36, 112 , II3.

Newton, 64 .

Otten, S. J., 99.

Origin, 273.

Osborn, 62, 124, 206.

Padberg, 34.

Pasteur, 31, 32, 33, 187.

Penck, 212.

Pius $X, 37,197$.

Plate, 65 .

Plato, 247, 273.

Pope, O. P., 108, 214.

Pruner-Bey, 208.

Quatrefages, 171, 172, 203.

Ranke, 174.

Reinke, 63, 145, 170. 
Rickaby, S. J., 220.

Robin, 59.

Rössle, 182.

Russel, 83.

Rutot, 158.

Sautola, 239 .

Sayce, 108.

Schaafhausen, 59.

Schlegel, 225.

Schwalbe, r59, r6r.

Schwann, 31, 57, 187 .

Scott, 182 .

Sedgwick, 135, 163.

Shakespeare, 24, 215, 216.

Sherman, 13 .

Siegfried, ro4.

Smyth, I24.

Socrates, 247.

Southall, 207 .

Spencer, 4I, 60, 82, 235, 268, 269.

St. Hilaire, Isidore Geoffroy, 74.

St. Hilaire, Etienne, 74 .

Steinmann, 86, 135 .

Steward, 64.

Suarez, 35, 97 .
Thomas Aquinas, St., 48, 8r, 97, 98, ror, ro4.

Thompson, 66.

Troland, 62.

Turton, 129, 139.

Tyndall, 22, 23.

Vigouroux, 215 .

Virchow, 86, 152, 155, 157, 159, 160, 171, 203.

Walkhoff, r7o.

Wallace, 48.

Walsh, Dr., 36, 178 .

Wasmann, S. J., 25, 26, 33, 54, $55,58,82,97,102,142,145$, 183.

Weismann, 74, 93, 100, 159.

Westermarck, 230.

White, 188.

Wiegand, 85, 86, 203.

Windle, 92, 101, I12, 132, 159, $164,202,213,249,267$.

Woodruff, 62, 124.

Wright, G. F., 206, 207, 2 roff.

Zahm, 56, 98.

Zittel, 162, 163. 


\section{INDEX OF SUBJECTS}

Altamira Cave, 240.

Anarchy due to materialism, $2 f f ., 15,268 f f$.

Animal life, rziff.

Anthropomorphism, II 5 .

Ape, alleged descent of man from $142 f f$.

Ape descended from man? I72ff., 178.

Ape-Man, 153ff., See "Missing link."

Appendix, vermiform, I84.

Augustinian theory of evolution, 96, 97, 98, 99.

Babylonian and Biblical versions of Creation, ro8.

Balzi Rossi Caves, 240.

Barbarism, modern, $249 f f$.

Batesonian theory, Ioo.

Bathybius Haeckelii, 59.

Bible and Science, ro6ff.

Biblical Commission, I 96.

Biogenetic law, r77ff.

Biologists, creed of, $30 \mathrm{ff}$.; not infidels, $3 \mathbf{I}$; Catholic, I88, 189.

Biology, connected with evolution, 30.

Birds and reptiles, 133.

Blood reaction, 181 iff.

Bolshevism, source of, $2 f f$., 15 .

Book of Wisdom, 276, 277.

Catholic scientists, attitude of, 8 ; sure of Faith, 95.

Catholicism and science, 33, $38 \mathrm{ff}$. See "Church."

Catholics and evolution, 95ff.
Causo-mechanical theory, $68 \mathrm{ff}$.

Chaldean tablets on Creation, 108, rog.

Chapelle-aux-Saints, 162.

Chronology, Biblical, 214, 215 ; and the "Six Days," Iro.

Church, no conflict with science, 29-37; welcomes scientific facts, 29ff., $38 \mathrm{fff}$., 197, I 98 ; favorable to scientific progress, 34, $38 f f . ;$ and Galileo case, $35 \mathrm{ff}$.; asks for facts, 45.

Civilization, early, 242ff., 247, 248 ; decline of. See "Devolution."

Colleges, doctrines taught in non-Christian, $13,14,270$.

Creation, and evolution, 54ff.; science affirming it, 63 ; necessity of, 77ff.; "Six Days," I06ff.

Creative acts necessarily required by philosophy, 190, r9r.

Creator, nature postulates a, III; philosophy points to a, 5off.

Criminal, not guilty, $17 f$.

Cro-Magnon races, 204, 240, 24 I.

Culture, early, 237ff., 245, 242ff., 25 I.

Darwinism, 72ff.; obsequies of, $86,9 \mathrm{r}$.

Deluge, 228, 245, 253.

Descent of man, Darwin's the- 
ory of, $82 \mathrm{ff}$.; alleged facts, I42ff., 194ff.

Design in nature, 79, 93, 156, I 66 .

Devolution, 228, 235, 247ff., $259 f f$.

De Vriesian theory, 195. See, "Saltatory theory."

Earth, formation of, I77ff.

Egyptian writings on Creation, 108.

Eolithic man, 215.

Eoliths, 158.

Evolution, two kinds, $6 \mathrm{ff}$.; and existence of God, 15, $50 \mathrm{ff}$., $65 f f . ;$ sane doctrine of, 25 ; not certain, 26, 68, 91, 92 ; Haeckelian creed of, $42 f f$.; and Creation, 54ff., 77ff.; principles regarding, 57,58 ; polygenetic and monogenetic, 72 ; of man, Darwin's theory of, 82ff.; and Faith, 88 ; dishonesty regarding, 92; Catholics and, 94ff.; Augustinian theory of, 96-99; Batesonian theory of, Ioo; and Genesis, 98, 99, ro3, ro6ff.; of horse, 135, 136; alleged, of man from ape, r42ff.; of ape from man, I72ff.; and biogenetic law, I77ff.; creative acts required in, rgoff.; and "Princeton Lectures," I68ff., 202ff.; alleged, of family, 23off.; and material development, 2 I $7 f f$.

Faith, blind, demanded by materialism, $47,60 f f$.

Family, origin of, 23off.

"Firmament," The, I2r, r22.

Ford machine, 69, 70.

Free will, questioned, I6ff.; denied by Haeckel, 46,47 .
Genesis, evolution and, ro6ff.; use of bara in, 56 .

Geology of earth formation, II 8 , II 9 .

Glacial period, 2roff.

God, existence of, Iff., I5, 5off., $53 f f ., 63 f f ., 190,191 ;$ and Darwin, 77ff.; reason demands, 265 .

Grimaldi races, 204.

Haeckel, creed of, 42ff.; deceptions of, 48,49 ; philosophy of, $46 \mathrm{ff}$. See, "Biogenetic law."

Heidelberg jaw, 159.

Homo primigenius, I6 1,163 .

Homo sapiens, 163, 176, 202, 204.

Homosimius precursor, 158 .

Horse, supposed evolution of, $135,136$.

Humor, lacking in materialism, 89.

Idolatry, origin of, 225.

Immortality, 2, 4 .

Iron, use of, 218, 219.

Knossos, civilization of, $243 \mathrm{ff}$.

Lamarckian theory, 7I, 73ff.

Learned names, idolatry of, 24 .

Le Moustier, men of, I6r.

Life, origin of, $53 f f . ;$ a philosophic question, 58 ; attempts to produce, 59; first appearance of, r24ff.

Light, first appearance of, Irgff.; sun, moon and stars, $128 f f$.

Likeness and descent, $165 f f$.

Man, creation of, 139ff.; reputed ancestry, r48ff.; spiritual activities of, 166 ; differing essentially from ape, r66ff.; arguments for descent, 175ff.; out of dust, 
198, 199; antiquity of, 202ff. Marriage, $232 f f$.

Materialism, logic of, Iff.; historic, 12; disadvantage to science, 40; philosophy of, 4I; Haeckelian creed of, $42 f f$.

Materialistic evolution, or Creation, $7 f f$; source of social evils, IO, II ; dogma of, I2ff., 42ff.; logic of, I6ff.; nature of, 22ff.; confusing philosophy with science, 25 ; from moneron to man, 45 ; philosophy of, 46ff., 279 ; blind faith demanded by, 47 , 60 ; impossibility of, 65ff.; unreason of, 69, 70, $265 \mathrm{ff}$; lack of humor, 89; propaganda of, IO, II, I45; and human soul, I66ff.; an incubus on science, 264 ; conclusions, 267. See, "Haeckel."

Mendelism, 34, 93 .

Metaphysics, Christian, 8, 9.

Minoan palaces, $243 f f$.

Missing link, 153ff., 189, 191ff.

Molchmaus, fictitious, 153,172 .

Moneron, the imaginary, 76 .

Monism, 42ff.; god of, 52 .

Monist league, 179 ; monks, 42 ; religion, $46 f f$.

Morality, modern materialist doctrine of, 20,21 .

Morphology, 165ff.

Mosaic narrative, ro6ff.

Myths, cosmological, ro8.

Natural selection, 75ff., 93; applied to man, 83,84 .

Neanderthal man, I6Iff., I63, $204,205 f f$.

Nebular hypothesis, eons of, IIO; various, III ; changes in, II2; application of, II $7 f f$. Neo-Lamarckianism, 73, 74, 91. Niagara Gorge, 2 Ioff.
Paleolithic man, 208, 209, 239ff., 244.

Pantheism, 65; the creed of Monism, 47.

Parents, our first, $217 f$.

Pastoral state, 22I, 256.

Piltdown skull, r59, 206.

Pithecanthropus erectus, I $_{4}$ ff., 169, 204, 205.

Plants, 126; first plant cell, I26.

Polytheism, growth of, 242.

Primates, pedigree of, $25, \mathrm{I}_{5} \mathrm{I}$.

Primitive man, 217ff., 227ff., $255 f$.

"Primitives," 251, 263.

"Princeton Lectures," I68ff., $202 f f$.

Pro-anthropos, I6o.

Profiteering, source of, $2 f f$.

Protococcus, 59.

Rationalism, logic of, rff., $16 f f$. Reason and Christianity, 48, 60.

Recapitulation theory, 180 . See "Biogenetic law."

Religion, origin of, 271, 272 ; and science. See, "Church."

Revelation, 272; no conflict with science, 29ff., $38 \mathrm{ff}$.; primitive, Iog.

Rudimentary organs, $183 f f$.

Saltatory theory, $87,88,203$. Savage, primitive man not a, $217 f f$., 222ff., 234, $251 f f$.

Savagery, origin of, 221, 228 ff., 234, 25 Iff.

Science, and religion, 29ff., $38 f f . ;$ affirms Creation, 63 ; and Bible, ro6ff.; master minds of, Christian, 187 . See, "Church."

Scientific hypotheses and Bible, II 3 .

Scientist's Catholic, attitude of, 


\section{INDEX OF SUBJECTS}

8 ; ideal position of, $40,4 \mathrm{r}$; list of, $188,189$.

Sexual selection, 76 .

Similarity, in creative design, $165, x 66$.

"Six Days," ro6ff.

Skull, human, 163,164 .

Socialism, philosophy of, 12, 142, 146, 147; morality of, 20, 146, 147; Haeckelian creed adopted by, 44, 48, 49 .

Sociologists, and evolution, I79, 180.

Sociology, ethical basis often adopted in, 15, 143.

Solutré, men of, 208.

Soul of man, 5, 64ff.; creation of, I39, I40, I67, I68, I70.

Species, no proof for change of, $6 \mathrm{ff}$., $27 \mathrm{ff}$.; natural and systematic, roz; distinct appear suddenly, 135 .
Spiral nebular theory, $\mathbf{I}_{7} \mathrm{ff}$. Spiritualism, 249ff.; among savages, 250.

Spontaneous generation, 7,59 .

Stone age, 219, 222, 223, 229.

Theophobia, 93.

Universities, doctrines taught in, 13, 14, 270; methods in non-Christian universities, 204.

Vision theory, Io7.

Vital principle, $64 f f$.

Vitalism, 68ff.

Wasp, the Hunting, 67 .

Woman, creation of, 200,201 . 



